\title{
INFLUÊNCIA DAS CONDIÇÕES FÍSICO-HÍDRICAS NAS TRANSFORMAÇÕES ESTRUTURAIS ENTRE HORIZONTES B LATOSSÓLICO E B TEXTURAL SOBRE DIABÁSIO
}

\author{
MIGUEL COOPER
}

Engenheiro Agrônomo

Orientador: Prof. Dr. PABLO VIDAL TORRADO

\begin{abstract}
Tese apresentada à Escola Superior de Agricultura "Luiz de Queiroz", Universidade de São Paulo, para obtenção do título de Doutor em Agronomia: Área de Concentração: Solos e Nutrição de Plantas.
\end{abstract}

P I R A C I C A B A

Estado de São Paulo - Brasil

Julho - 1999 


\title{
Dados Internacionais de Catalogação na Publicação (CIP) DIVISÃO DE BIBLIOTECA E DOCUMENTAÇÃO - Campus "Luiz de Queiroz"/USP
}

\author{
Cooper, Miguel \\ Influència das condiçōes fisico-hidricas nas transformaçōes estruturais entre \\ horizontes B latossólico e B textual sobre diabásio / Miguel Cooper. - - Piracicaba, \\ 1999. \\ 128 p. : il. \\ Tese (doutorado) - Escola Superior de Agricultura Luiz de Queiroz, 1999. \\ Bibliografia. \\ 1. Diabásio 2. Formação do solo 3. Lotossolo 4. Morfologia do solo 5. \\ Propriedade fisico-quimica do solo I. Titulo
}

CDD 631.44

"Temmitid a copla total o parcial feste 6 ocumento, 0 es de que citada a fonte 0 lutor" 
À LULI e CAMILA que com tanto amor e carinho me apoiaram neste empreendimento OFEREÇO... DEDICO. 


\section{AGRADECIMENTOS}

- Ao Prof. Dr. Pablo Vidal-Torrado pela orientação, apoio, incentivo, dedicação e principalmente pela grande amizade durante todos estes anos de trabalho.

- À Escola Superior de Agricultura "Luiz de Queiroz" e ao Departamento de Ciência do Solo pela oportunidade.

- À FAPESP - Fundação de Amparo à Pesquisa do Estado de São Paulo pela bolsa concedida.

- À CAPES - pela bolsa de doutorado sanduiche concedida.

- Ao INRA (Institut Nationale de Recherche Agronomique) e ao USARQ (Unité de Sol-Agronomie de Rennes-Quimper) pela oportunidade de trabalhar nos seus laboratórios

- Aos pesquisadores. Pierre Curmi e Michel Grimaldi pelo recebimento, pela coorientação. ajuda e amizade durante meu estágio no seu laboratório em Rennes, França.

- À Prof. Dra. Selma Simões de Castro pela ajuda e apoio na obtenção da bolsa de Doutorado "Sanduiche".

- Aos técnicos de laboratório Betty e Vladimir pela ajuda e apoio durante a realização das análises físicas, e de Raio-X, e principalmente pela amizade e confiança.

- Aos colegas, Peterson, Nanni, Silvia, Cassio, Mauricio, Vincent, Jerome. Fred, Mathurin. Paulo, Veronique, Virginie e Solenne pela colaboração e paciência.

- À minha familia, em especial ao meu tio Fernando que com seus conselhos e filosofia me ajudaram a ver a vida com outra perspectiva.

- A todos os que de alguma forma contribuiram para a realização deste trabalho. 


\section{SUMÁRIO}

PÁGINA

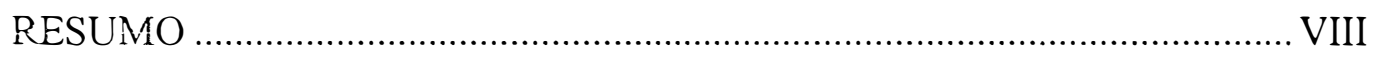

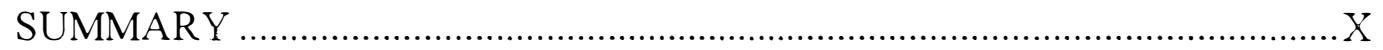

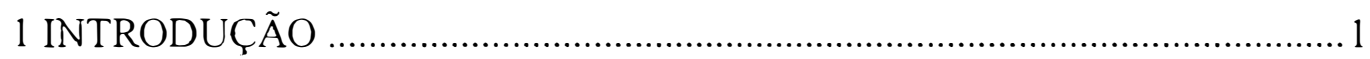

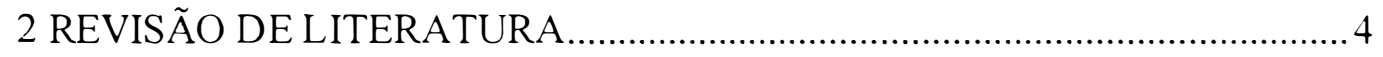

2.1 Origem da estrutura do horizonte B latossólico............................................... 4

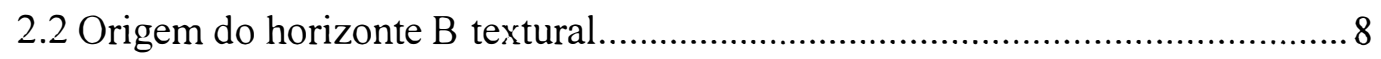

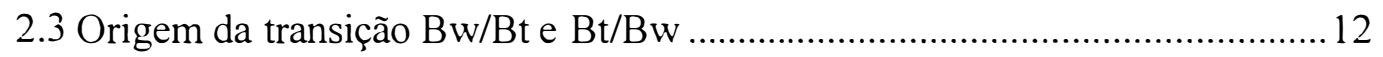

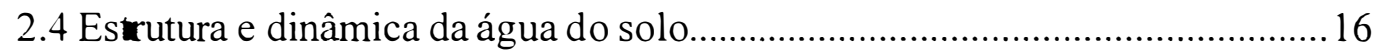

2.5 Estudos quantitativos da estrutura do solo...................................................... 19

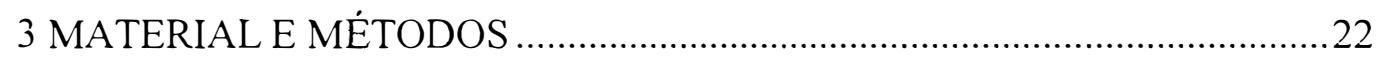

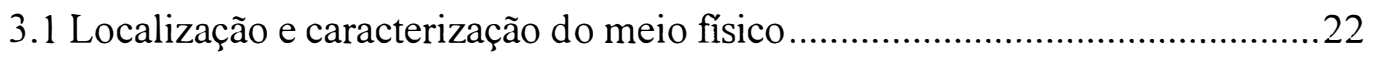

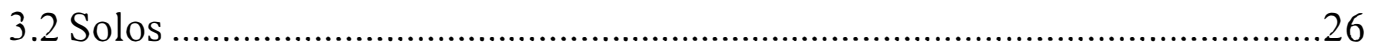

3.3 Levantamento e caracterização morfológica ……………………………….....28

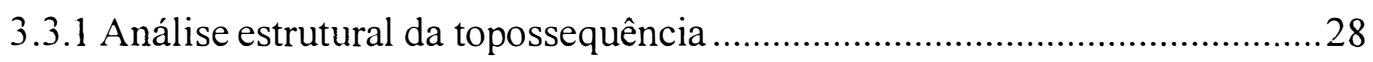

3.4 Estabelecimento dos locais de amostragem e amostragem dos solos .............29

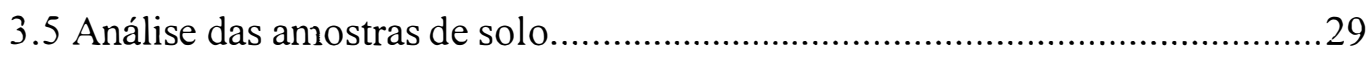

3.5.1 Análise granulométrica das amostras de solo .............................................29

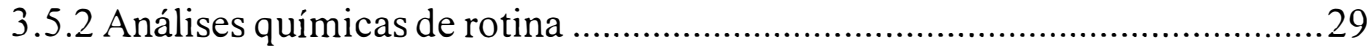

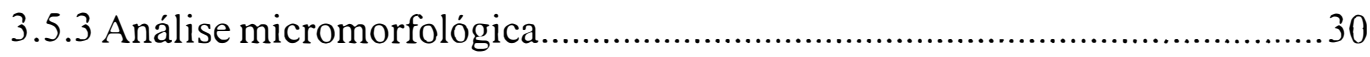

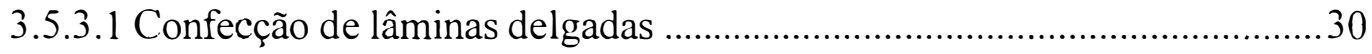

3.5.3.2 Descrição e interpretação das lâminas delgadas ..........................................31

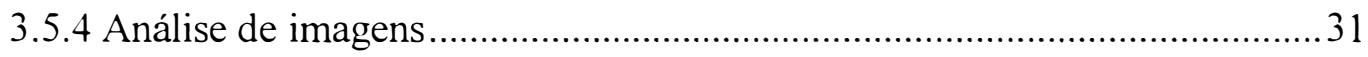

3.5.4.1 Parametrização das características porais .................................................. 32

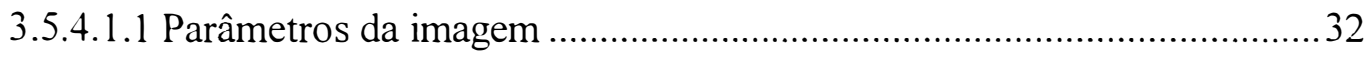

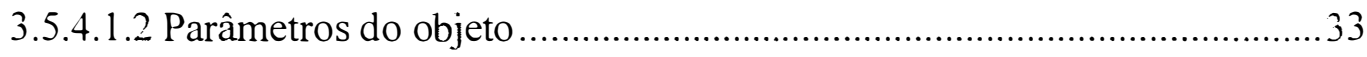

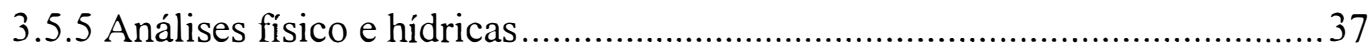

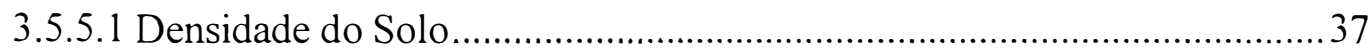




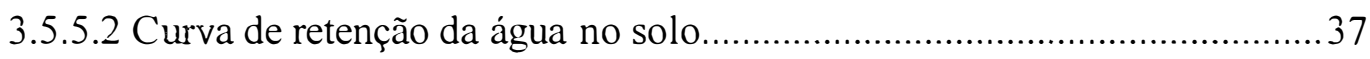

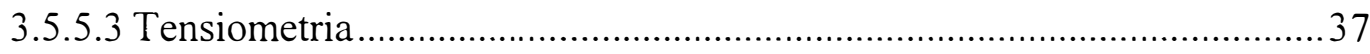

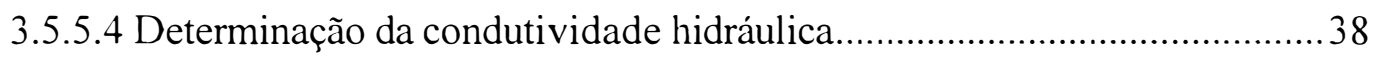

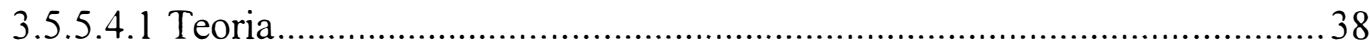

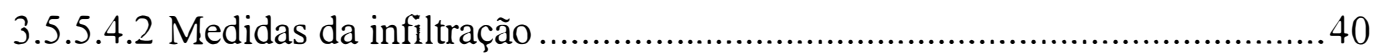

3.5.6 Microscopia eletrônica de varredura ........................................................... 41

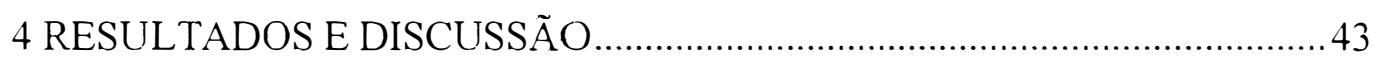

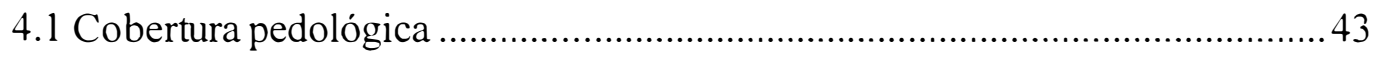

4.1.1 Organização dos solos ao longo do transeto.................................................43

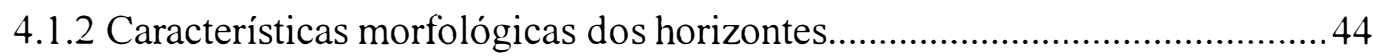

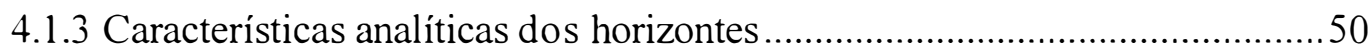

4.1.4 Características micromorfológicas dos horizontes da transição Bt-Bw-

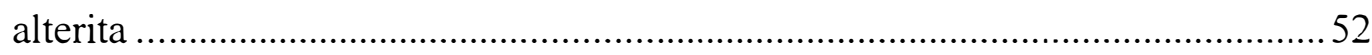

4.1.5 Características submicroscópicas e microanalíticas dos horizontes da

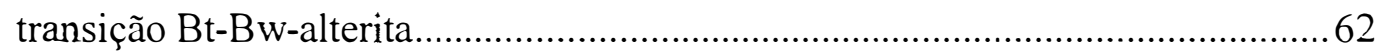

4.2 Análise do espaço poral por análise de imágens.............................................70

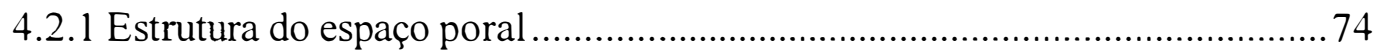

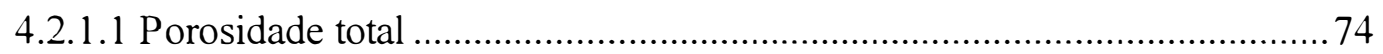

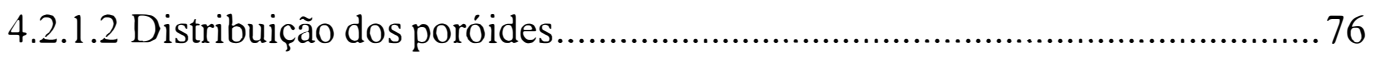

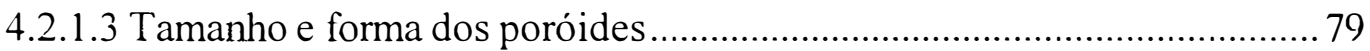

4.2.2 Interpretação da estrutura do espaço poral.................................................... 81

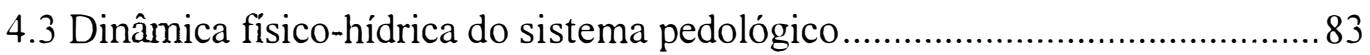

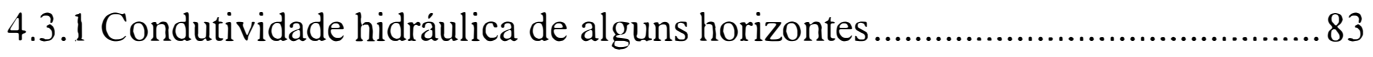

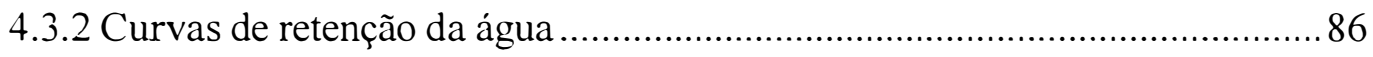

4.3.3 Variações sazonais do potencial total no solo ..............................................92

4.3.4 Variações do potencial total do solo durante eventos chuvosos ................. 100

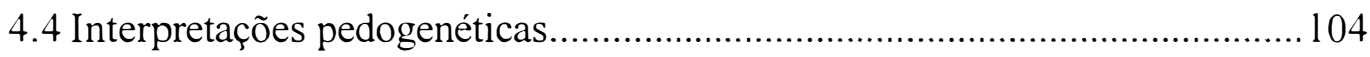

4.4.1 A organização dos horizontes e os processos pedogenéticos......................104

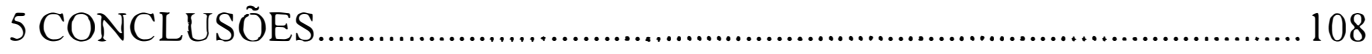


REFERÊNCIAS BIBLIOGRÁFICAS ..................................................... 110

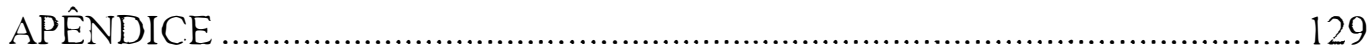




\title{
INFLUÊNCIA DAS CONDIÇÕES FÍSICO-HÍDRICAS NAS TRANSFORMAÇÕES ESTRUTURAIS ENTRE HORIZONTES B LATOSSÓLICO E B TEXTURAL SOBRE DIABÁSIO
}

\author{
Autor: Miguel Cooper \\ Orientador: Prof. Dr. Pablo Vidal Torrado
}

\section{RESUMO}

Numa área situada dentro do campus da USP em Piracicaba (SP) várias questões de formação de solos foram estudadas, como a transição entre um horizonte microagregado (granular pequena a muito pequena) e outro com estrutura macroagregada poliédrica (em blocos), a origem do horizonte microagregado e a formação de cutãs de iluviação. Desta forma, foi realizado um estudo da dinâmica da água na vertente, uma quantificação da porosidade, um estudo da forma e distribuição espacial dos agregados para procurar entender os processos que levam à transformação da estrutura microagregada em macroagregados poliédricos centimétricos, à formação de microagregados e cutãs de iluviação.

O estudo foi realizado no topo e ombro de uma topossequência de $600 \mathrm{~m}$ de extensão. Estudos analíticos, morfológicos, micromorfológicos, submicroscópicos e de análise de imagens foram feitos em três trincheiras distribuídos nestes segmentos da seqüência. Um estudo da dinâmica da água na vertente foi realizado através de medições físico-hídricas tais como a condutividade hidráulica, curvas de retenção e o seguimento do potencial total dos solos em duas escalas, uma sazonal e outra durante os eventos chuvosos.

A transição vertical e lateral entre o horizonte Bw e Bt foi atribuída à coalescência dos microagregados provocada pela aparição de tensões durante um período mais seco que o atual. A passagem posterior para um clima mais úmido com estação seca definida, provocaria ciclos alternados de umedecimento e dessecação mais freqüentes que resultam 
na fissuração do material formando os agregados poliédricos. Concomitantemente a estes processos, a argiluviação estaria presente, provocando a cimentação dos microagregados e preenchendo o espaço poroso.

O estudo da gênese dos microagregados mostrou a participação de mais de um processo na formação destes. Três processos foram evidenciados: o da ação mecânica da mesofauna, o da formação de microagregados por processos físico-químicos e o da fissuração do fundo matricial por processos de expansão e contração formando microagregados poliédricos. Os microagregados que predominavam eram os de origem físico-química sendo formados a partir de uma reorganização e adensamento da estrutura particular caulinítica encontrada na alterita do diabásio.

Os cutãs de iluviação (ferriargilãs) teriam a sua origem nos processos de hidromorfia temporária que ocorrem nos horizontes superficiais dos solos. Estes provocariam a desestabilização das ligações ferro-argila facilitando assim a mobilização e redistribuição da argila e ferro. 


\title{
INFLUENCE OF THE PHYSICO-HYDRICAL CONDITIONS ON THE STRUCTURAL TRANSFORMATION BETWEEN AN OXIC AND AN ARGILLIC HORIZON OVER DIABASE
}

\author{
Author: Miguel Cooper \\ Adviser: Prof. Dr. Pablo Vidal Torrado
}

\section{SUMMARY}

In an area situated in the USP campus in Piracicaba (SP) various soil fomation questions were studied, such as the transition between microaggregated and blocky structure horizons, the origin of the microaggregated horizon and the formation of illuvial cutans. To understand the processes that influence these soil formation questions, a study of the toposequence's soil water dynamics, a quantification of the soil porosity and a study of the morphology and spatial distribution of the aggregates were performed.

This study was done on the summit and shoulder segments of a $600 \mathrm{~m}$ toposequence. Analytical, morphological, micromorphological, electron microscopy and image analysis studies were done in three pits distributed on these segments. Physicohydrical measures such as the hydraulic conductivity, water retention curves and the daily and during the rain events measurement of the water head were done to study the toposequence's soil water dynamics.

The lateral and vertical transition between the microaggregated and blocky structure horizons was attributed to the coalescence of microaggregates due to the apparition of tensions during a drier period than present. A later transition to a more humid climate with a well defined dry season. leads to more frequent and less energetic wetting and drying cycles that result in the fissuration of the densed material forming the blocky structure. Parallel to these processes, argilluviation is present filling the pore space and leading to the cimentation of the microaggregates.

More than one process participates in the formation of microaggregates. Three processes were evident: the mechanical action of the mesofauna, the formation of 
microaggregates by geochemical processes and the intense fissuration of the soil matrix by contraction and expansion processes forming poliedric microaggregates. The most common type of microaggregates were those formed by geochemical processes. These were formed by a re-organization and densing of the caulinitic particular structure found in the diabase alterite.

Temporary hydromorphic conditions, identified in the soils superficial horizons, would be the origin of the illuvial cutans (ferri-argillans). These conditions lead to the destabilization of the iron-clay bonds provoking the redistribution and mobilization of iron and clay. 


\section{INTRODUÇÃO}

O conhecimento de sistemas naturais requer estudos com o maior grau de detalhe possivel para poder explicar os processos que levaram à formação do ambiente atual e sua dinâmica. Quando o sistema estudado é o sistema solo o mesmo princípio é aplicado e, assim, para entender como o solo se formou e qual é a sua dinâmica atual precisa-se efetuar estudos de detalhe.

Para isto na maioria dos estudos de gênese de solos a abordagem deve ser a mais ampla possível Uma vez que os fatores que afetam a formação de solos são muitos e atuam das mais diversas formas. Para poder cercar e entender os processos que levam à formação de solos deve-se recorrer a diferentes áreas da ciência como a Física, Química, Biologia, Mineralogia e Geologia. Assim, estudos geoquímicos e fisico-químicos associados a estudos da dinâmica da água em perfis de solo e vertentes, fornecem informações que vão explicar o equilíbrio e a dinâmica física e química dos diferentes processos estudados.

É importante entender a problemática das relações entre as grandes organizações pedológicas, tais como as descritas pelos pedólogos estruturalistas, e a dinâmica da água das unidades da paisagem (interflúvio, vertente, bacia), como também das relações entre estrutura e propriedades hidrodinâmicas do solo na escala do horizonte pedológico. De fato, o comportamento hidrodinâmico intrínseco dos horizontes assim como as interações que resultam das transformações destes dentro do sistema pedológico serão determinantes da dinâmica da água do solo. Assim pode-se esperar que o estudo das relações entre a estrutura dos horizontes e seu comportamento hidrodinâmico permita levar 
ao conhecimento do papel da estrutura do sistema pedológico (geometria e disposição relativa dos horizontes, limites entre horizontes) sobre a dinâmica hídrica.

Várias são as hipóteses que aparecem na literatura para explicar a transformação estrutural entre horizontes microagregados e horizontes com agregados poliédricos centimétricos em solos sem gradiente textural. Todas elas se baseiam em dados qualitativos morfológicos. Acredita-se que esta transformação estaria intimamente ligada às relações existentes entre as estrutura do solo e o seu comportamento hidrodinâmico. Por isso, para melhor entender estas relações é indispensável dispor de dados quantitativos sobre a sua organização estrutural e dinâmica da água. Para este tipo de quantificação a escala do horizonte é ideal, tanto para a estrutura como para as características hidrodinâmicas. Assim, a utilização da análise de imagens, que fornece a caracterização morfológica do espaço poral, permite a quantificação da estrutura do horizonte. Da mesma forma, para a caracterização hidrodinâmica do solo as propriedades de interesse são a retenção e fluxo da água. Estas propriedades podem ser quantificadas, respectivamente, atraves de curvas de retenção da água no solo e atraves do levantamento das variações espaço-temporais do potencial total dentro do solo utilizando a tensiometria.

Dentro da problemática do presente trabalho, foram propostas duas hipóteses de trabalho:

a) A transformação da estrutura microagregada em macroagregada poliédrica se daria em condições de clima mais seco que o atual, que provocaria a aparição de tensões devido à existência de estações muito distintas levando à formação de um meio energeticamente contrastante que provocaria a coalescência dos microagregados.

b) A passagem para um clima úmido atual, porém com estação seca definida, provocaria ciclos alternados de umedecimento e dessecação mais freqüentes que resultam na fissuração do material e a formação de agregados e microagregados poliédricos.

O objetivo do presente trabalho é, assim, estudar a dinâmica da água na vertente, quantificar a porosidade, estudar o tamanho, a forma e distribuição espacial dos agregados 
para procurar entender os processos que levam `a transformação da estrutura microagregada (granular pequena a muito pequena) em macroagregados poliédricos centimétricos (em blocos) e vice-versa. 


\section{REVISÃO DE LITERATURA}

\subsection{Origem da estrutura do horizonte B latossólico}

O horizonte B latossólico é o horizonte diagnóstico dos Latossolos e aparece em alguns solos intermediários, como por exemplo a Terra Roxa Estruturada Latossólica e o Podzólico Vermelho-Escuro Latossólico. Este horizonte caracteriza-se por ser muito homogéneo. Morfologicamente pode apresentar estrutura maciça ou em blocos subangulares fracos que se desfazem em microagregados de grau forte no caso de apresentar textura argilosa. São horizontes altamente intemperizados com poucos minerais alteráveis nas frações areia e silte. A fração argila apresenta uma mistura de caulinita e óxidos, hidróxidos e oxihidróxidos de ferro e/ou alumínio (Buol \& Eswaran. 1978 e Stoops, 1983).

Os microagregados, elementos característicos de um horizonte latossólico. podem apresentar várias formas: esféricas, ovais ou poliédricas. Existem diversos estudos sobre a formação destes tipos de agregados que mostram origem diversa (Buol \& Eswaran. 1978; Stoops, 1983 e Stoops \& Buol, 1985).

Beadou (1972) estudando os solos ferralíticos da República Centro-Africana observou que os microagregados estão intimamente ligados à pedogênese ferralítica e que apresentam uma estrutura complexa com um núcleo rico em óxidos e hidróxidos de ferro envolvido por uma camada de fundo matricial pouco modificado. A formação de microagregados é acompanhada por uma modificação do plasma que pouco a pouco vai se individualizando e passa de massépico para insépico ou assépico. Ele explica porque a porosidade fissural que existe quando os microagregados são formados se transforma em 
porosidade de empilhamento, onde os microagregados estão bem individualizados. Em trabalhos posteriores este autor observou uma intensa fissuração do plasma nos horizontes superficiais originando os microagregados em solos do Gabão (Beadou et al., 1977) e em 1987, novamente na República Centro-Africana, Beadou et al. (1987) concluíram que os microagregados resultam da associação de argilas com a hematita e que as argilas estão orientadas paralelamente às bordas dos agregados.

Pedro et al. (1976) explicaram dos microagregados ovóides dos Latossolos como sendo de evolução geoquímica. Eles propuseram que o processo de pedogênese ferralítico é formado por dois estágios principais. O primeiro corresponde à alteração ferralítica havendo neoformação de um material ferrocaulinítico. O segundo corresponde ao desenvolvimento de um horizonte microagregado típico devido ao total desaparecimento dos minerais primários da rocha e da individualização de um complexo de alteração essencialmente caulinítico-gibbsítico e à ocorrência de fenômenos secundários como a dessaturação do complexo de adsorção, a ferritização do complexo argiloso e uma cristalização progressiva dos compostos ferriferos independentes.

Muller (1977), em trabalho conduzido na República dos Camarões, explicou a formação dos horizontes óxicos como uma pedogênese recente ou atual. Mostrou que os microagregados esféricos são formados por um simples rearranjamento do plasma sem que apareçam mudanças na cor devido a eventuais deslocamentos do ferro. Este processo parece ser uma fragmentação fisica que ocorre a partir dos horizontes mais profundos em direção à superfície e aparece como uma reorganização biaxial de uma estrutura insépica ("neostrians"), sem que ocorra nenhuma transformação de natureza geoquímica. O autor classifica os microagregados em cinco tipos: estruturais, formados a partir do processo de microestruturação ou separação do plasma; reliquiais, herdados do processo de intemperismo; ferríticos, formados por um processo de ferritização anterior; zoogenéticos; formados pela pedoturbação de origem biológica e complexos, que são formados pela agregação de microagregados de tamanho menor. 
A formação de microagregados poderia ocorrer segundo Chauvel et al. (1978) a partir de uma matriz anisotrópica composta de caulinita e hidratos de ferro. Zonas pequenas $(100 \mu \mathrm{m})$ de cor mais vermelha estariam se formando nesta matriz. como resultado de uma organização diferencial do ferro. Estes micronódulos se individualizariam quando a matriz que os circunda desaparece devido à sua alta mobilidade. como resultado da desferrificação parcial.

Utilizando técnicas de microscopia ótica e eletrônica para a observação dos microagregados feitos pelos cupins em amostras coletadas na Costa do Marfim e Congo e de material produzido pelos cupins em laboratório, Eschenbrenner (1986) determinou a microfábrica, a composição geoquímica e mineralógica dos microagregados. Ele observou que estes microagregados eram orgânicos ou minerais ou ambos e que apresentavam a forma característica oval a esféricos. Com isso concluiu que este material formado pelos cupins é muito similar aos microagregados encontrados nos Latossolos, podendo resultar da atividade dos cupins em condições tropicais, processo que ele chamou de bioagregação. Vários trabalhos mostram o papel secundário da formação de microagregados pela mesofauna do solo (Chauvel, 1977; Muller, 1977; Stoops, 1983 e Trapnell \& Webster, 1986). No entanto Eschenbrenner foi um dos primeiros a dar uma importância maior a este processo de formação de microagregados. No Brasil, Miklós (1992 e 1993) observou a formação de microagregados ovais por cupins em solos formados sobre basalto em Botucatu (SP), ressaltando a importância deste processo na formação de Latossolos. VidalTorrado (1994) observou a presença de microagregados de origem biológica em uma topossequência no distrito de Tupi, Piracicaba (SP).

Trapnell \& Webster (1986), estudando solos no leste e centro da África, observaram quatro tipos de microagregados. Os fragmentários, formados pela fissuração de pedes maiores por alternâncias de ciclos úmidos e secos, os granulares que são microagregados irregulares que são formados por umedecimento gradual, os granuliformes que desenvolvem superfǐcies arredondadas após umedecimento gradual e os 
microgranulares, com forma quase esférica e que se formariam por processos geoquímicos ou pela atividade da mesofauna.

Fazendo uma caracterização energética dos sistemas plásmicos dos grandes conjuntos pedogenéticos, Pedro (1987) estabeleceu dois grandes conjuntos. No primeiro, ocorre um meio pouco contrastante energeticamente ( $\mathrm{pF}$ variando de 1 a 2 ) onde a umidade relativa do ar é alta e as temperaturas maiores que ${ }^{\circ} \mathrm{C}$. No segundo sistema o meio é contrastante energéticamente devido à existência de estações climáticas muito distintas durante o ano ( $\mathrm{pF}$ variando de 0 a 6 ). No primeiro caso ocorre um fenômeno convergente. Neste caso encontra-se um meio úmido, muito filtrante, com soluções diluídas onde os elementos $\mathrm{Al}$ e Fe tem um papel fundamental nas interfaces, em função da sua hidrofobia. Todos estes parâmetros se conjugam para elaborar organizações com geometria fixa (esféricas ou ovais) e que aparecem geralmente sob formas de volumes com superfícies externas mínimas e com dimensões compatíveis $(100 \mu \mathrm{m})$ com os fenômenos físicos preponderantes.

Cambier' na sua tese de doutorado, citado por Pedro (1987), mostrou que nos Oxissolos as partículas de caulinita formam policristalitos formando unidades chamados de micro-domínios ( $1 \mu \mathrm{m}$ de diâmetro). Estes policristalitos se formam pela união de cristais de caulinita dispostos paralelamente e ligados uns aos outros por pontes de Fe. Estes micro-domínios orientados são a base para a formação dos micro-nódulos característicos dos Oxissolos.

Num trabalho semelhante e utilizando técnicas de microscopia eletrônica Santos et al. (1989) estudaram a composição de microagregados e o arranjo das suas partículas. Observaram que o mineral de argila dominante apresentava baixo grau de ordem estrutural, densamente empacotado, caulinítico e orientado ao acaso. Oxi-hidróxidos de Fe de baixo grau de ordem estrutural (provavelmente ferrihidrita), que existem como agregados

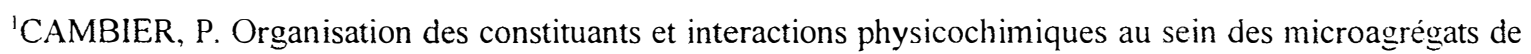
sols. Application au système ferralitique kaolinite-oxyde de fer. Thése Paris, INRA, 226p. 1986. 
individuais preenchendo o espaço entre as partículas de caulinita, tendo a matéria orgânica um papel importante na união das partículas de argila. Concluíram os autores que as análise de seções ultradelgadas sugerem que a combinação de partículas de argilas orientadas ao acaso, a matéria orgânica e os agregados de Fe dão aos microagregados. uma natureza isotrópica.

Três condições foram propostas por Dexter (1988) para a formação de microagregados. Primeiro, quaisquer ligações existentes entre as partículas do solo devem ser quebradas por processos mecânicos; segundo, a físico-química do solo deve ser tal, que aglomerados de partículas de $10-20 \mu \mathrm{m}$ de diâmetro possam se formar; e terceiro, o potencial da água deve ser suficiente para formar meniscos entre os aglomerados para juntá-los e formar microagregados de até $150 \mu \mathrm{m}$.

Beauvais \& Tardy (1991), estudando a degradação de couraças ferruginosas em clima tropical úmido sob floresta, afirmaram que o desmantelamento das couraças resulta de um efeito conjugado da umidade (precipitações anuais maiores que $1600 \mathrm{~mm}$ ), da decomposição da matéria orgânica e da respiração das raízes que provocam a hidratação e redução, responsáveis pela transformação da hematita em goetita, da caulinita em ģibbsita e da dissolução seletiva do ferro através da ligação com o alumínio. Concluíram que em todos os lugares onde ocorre o desenvolvimento de uma floresta a formação de solos ferralíticos micronodulares ocorre às expensas de couraças ferruginosas formadas no passado sob clima tropical muito contrastante.

Vidal-Torrado (1994) observou que na área de estudo no distrito de Tupi, Piracicaba (SP), a formação de microagregados poderia ter ocorrido por mais de um

processo. Ficou evidenciado nas descrições realizadas por ele o processo de microestruturação (Muller, 1977), a ação da mesofauna e microagregados herdados do retrabalhamento do material latossólico ocorrido na evolução do vale.

\subsection{Origem do horizonte $B$ textural}


O horizonte B textural é um horizonte mineral subsuperficial onde houve incremento de argilas orientadas ou não. Vários processos podem explicar esta distribuição das argilas. Birkeland (1984) citou três processos para a formação deste horizonte: o primeiro seria aquele em que os constituintes das argilas são derivados do intemperismo que ocorre na parte superior do perfil e que se movem para baixo em solução com a água que percola e precipitam como minerais de argila no horizonte $\mathrm{B}$; o segundo refere-se às argilas formadas "in situ" pelo intemperismo de minerais no horizonte B; e o terceiro refere-se às argilas que se movem como partículas em suspensão na água de percolação e que se acumulam no horizonte $\mathrm{B}$ devido à floculação ou a constrições nos poros através dos quais a água se move. Adicionou o autor que sem dúvida as argilas encontradas no horizonte B são formadas pelos três processos, mas que a importância relativa de cada um deles varia com o tipo de solo.

Eswaran \& Sys (1979) explicaram a formação do horizonte Bt como sendo resultado de três processos: dispersão, translocação e acumulação, dando ênfase a presença de cerosidade e a presença de cutãs como características principais para a classificação destes horizontes como Bt.

Nettleton et al. (1969) encontraram vários solos que apresentavam acúmulo de argila no horizonte B e cerosidade no campo e que não apresentavam cutãs de iluviação nas lâminas delgadas. Explicaram este fato por duas razões: primeiro, a formação de argilas orientadas "in situ" pela ação de ciclos de umectação e dessecação ("stress cutãs") e segundo, estes mesmos processos de expansão e contração podem provocar a destruição dos "cutãs" de iluviação ou não formar superfĩcies de "pedes" suficientemente permanentes como para permitir o acúmulo e formação destes "cutãs".

Isbell (1980), num trabalho de revisão sobre o conceito de Bt, já concluíra que apesar de que a iluviação de argila poder ser evidenciada no campo, havia também evidência crescente de que sem o estudo de lâminas delgadas a sua identificação seria 
difícil. Os estudos revisados por este autor mostraram que às vezes havia uma falta de correlação entre a cerosidade observada no campo e a quantidade de cutãs de iluviação observada nas lâminas delgadas.

Para identificar horizontes Bt no campo Fedoroff \& Eswaran (1985) apresentaram três características das quais uma ou mais podem ser utilizadas para caracterizar um Bt. Estas são: presença de um horizonte eluvial acima do horizonte Bt, presença de uma estrutura primária com estrutura secundária ou terciária em blocos e ausência de microgrânulos característicos dos Latossolos. Segundo estes autores, a argila nos horizontes Bt pode se originar: a) de um material transportado e misturado no solo: b) de um material intemperizado; c) de um material iluviado fino misturado pela fauna do solo; d) de um material herdado de um horizonte óxico; e) de feições pedológicas na forma de cutãs de iluviação ou preenchimentos correspondendo à argiluviação presente; f) de fragmentos de feições argilosas provavelmente herdados do material de origem e formados quando o horizonte foi perturbado ou transportado; e g) de feições pedológicas perturbadas correspondentes a argiluviações passadas.

Pedro (1987) explicou a formação de macroestruturas em um meio onde encontram-se períodos energeticamente contrastantes devido à existência de estações opostas (variações de pF durante o ano de 0 a 6) provocando a ação de forças de cisalhamento consecutivas aos fenômenos de expansão por ocasião de cada ciclo de reumectação sazonal.

O processo de degradação do horizonte Bt é considerado por vários autores como um processo importante na formação deste horizonte. Jimenez Rueda \& Demattê (1988) observaram a presença de silãs, que podem indicar a sílica liberada da estrutura do mineral de argila. Castro (1989) observou a degradação do topo do horizonte Bt por um empobrecimento químico do ferro seguida de uma mecânica que deixa bandas onduladas residuais de acumulação dupla no seio do horizonte E. Dijkerman \& Miedema (1988) estudando solos de Serra Leoa explicaram que o aumento de argila desde o horizonte A 
destruição de argilas do topo do Bt pelo processo de ferrólise (Brinkman, 1970). VidalTorrado et al. (1991) estudando um Podzólico Vermelho Amarelo observaram a degradação do horizonte $\mathrm{Bt}$ evidenciado por mecanismo pedogenético ocorrendo sucessivamente iluviação de argila, redução da porosidade do topo do $\mathrm{Bt}$, encharcamento temporário do topo do Bt e degradação ou remoção lateral dos finos do topo do Bt.

Estudando Nitossolos no Quênia, Sombroek \& Siderius (1976) não encontraram na literatura um processo específico para explicar a formação destes solos. Os processos responsáveis pela formação de Ferralsolos e Acrisolos/Nitossolos (ferralitização versus argiluviação) não explicam satisfatoriamente a morfologia e características dos Nitossolos. Para poder entender os processos que levaram à formação destes solos, estes autores salientaram que um bom começo para delinear um processo específico é a ocorrência geral de agregados em blocos muito estáveis e suas superficies brilhantes características, que também ocorrem nas alteritas. Mas, a informação existente para a formação dos pedes em forma de blocos é pouco conclusiva. A ocorrência de superfĩcies lisas e brilhantes devido à argiluviação parece altamente improvável, não só por sua ocorrência nas partes mais profundas do perfil, mas também pela sua composição (óxidos de ferro e manganês). Segundo estes autores, a formação destas superfícies lisas e brilhantes resulta de processos de difusão causando concentrações de plasma na forma de cutãs compostos (ferrãs, mangãs), localmente cobertos por argilãs, e não condiz com as condições aeróbicas nas quais os Nitossolos se encontram. Atribuir a formação destas superficies a processos de estresse não explicaria a concentração dos óxidos, pois estes se movem dentro da matriz dos pedes sob condições de drenagem livre. Os autores propuseram que a migração de óxidos ocorre sob a influência de micro-magnetismo induzido por um pequeno cisalhamento entre os pedes, processo que denominaram de "metalização".

Sombroek \& Siderius (1981) consideraram que vários processos ocorreriam na formação destes Nitossolos: formação de argila de atividade baixa (caulinita e sesquióxidos); translocação de argilas; homogeneização pela fauna do solos (cupins, 
formigas, vermes, etc.), particularmente evidente nos primeiros $100 \mathrm{~cm}$ do solo causando a destruição ou deformação de cutãs e a formação de estrutura granular a estrutura em blocos subangulares; e a "nitidização", processo que causa a formação de estrutura em blocos angulares bem definidos com superfïcies brilhantes que podem ser lisas ou estriadas. Evidências micromorfológicas mostraram a presença de "argilãs" nos pedes, enquanto que a estriação nas mesmas superfícies indicou que a micro-expansão e micro-contração podem resultar em faces de pressão ou micro-slickensides.

Estudando as propriedades micromorfológicas dos Nitossolos, Creutzberg \& Sombroek (1987) definiram uma combinação de propriedades micromorfológicas que chamaram de "Nito-argillic Syndrome", que caracterizam o horizonte nito-argílico. Dentro das características apresentadas pelos autores, destaca-se a formação de ferri-argilãs finos nos poros como sendo a feição que mais caracteriza o horizonte nito-argílico, chamando-os de "lepto-coatings". Eles explicam a formação destes "lepto-coatings" como sendo resultado da reorganização local (estresse) da argila orientada anteriormente depositada dentro do horizonte. A presença generalizada dos "lepto-coatings" no horizonte nitoargílico combinado com a ocorrência de superfícies de fraqueza no fundo matricial. podem ser considerados responsáveis pela presença de superfícies lisas e brilhantes que caracterizam o horizonte nito-argílico no campo.

Sombroek (1990) reafirmou os processos que originam a formação dos Nitossolos como a presença de alguns poucos ferri-argilãs de iluviação e uma maior abundância de "lepto-coatings" nos poros. Admitiu entretanto que a natureza exata das superfícies brilhosas nos pedes é ainda incerta (exudação, metalização, cisalhamento, e/ou iluviação), assim como a origem das formas dos pedes.

\subsection{Origem da transição $\mathrm{Bw} / \mathrm{Bt}$ e $\mathrm{Bt} / \mathrm{Bw}$}


$\mathrm{Na}$ paisagem encontram-se dois tipos de transições laterais do tipo $\mathrm{Bw} / \mathrm{Bt}$ : uma onde ocorre a transição entre o horizonte com estrutura microagregada $(\mathrm{Bw})$ para o horizonte com estrutura poliédrica de acúmulo de argila $(\mathrm{Bt})$ e outra onde encontra-se a transição de horizontes com estrutura poliédrica de acúmulo de argila (Bt) para o horizonte com estrutura microagregada $(\mathrm{Bw})$.

Lepsch \& Buol (1975) estudando uma topossequência Oxissolo-Ultissolo associaram os Oxissolos às superfícies mais antigas e os Ultissolos às mais jovens. Concluíram que o horizonte óxico se formava a partir da floculação e compactação do plasma formando microagregados, sendo homogeneizado por processos de pedoturabação enquanto que o desenvolvimento dos horizontes argílicos devia-se principalmente ao processo de translocação de argilas. Outros trabalhos também citam a importância da translocação da argila na formação de horizontes argílicos em Ultissolos e Alfissolos (Birkeland, 1984; Bullock \& Thompson, 1985 e Fedoroff \& Eswaran, 1985).

Segundo Perecin \& Campos (1976), a formação de uma Terra Roxa Estruturada a partir de um Latossolo Roxo pode ter ocorrido pela deposição de argila iluviada sobre a fábrica intertéxtica dando origem à fábrica porfirosquélica e ao aparecimento de fissuras. Concluíram que a argila iluviada, que atualmente está se depositando nas fissuras, provém de períodos de iluviação recente.

Lepsch et al. (1977) explicaram a formação de horizontes argílicos nas encostas íngremes adjacentes a Oxissolos pelo movimento lateral da água nos horizontes superficiais provocando uma redução, por curto espaço de tempo, dos óxidos de ferro hidratados provocando a remoção destes. Isto provoca rompimento nas ligações argilaferro, liberando as argilas para serem transportadas e acumuladas em posições mais baixas, formando um horizonte argílico. Processo semelhante foi descrito por Queiroz Neto et al. (1981) para explicar a passagem lateral de horizontes Bw para horizontes Bt numa vertente em Marília (SP) e demonstrado micromorfológicamente por Castro (1989). 
A transição entre solos ferralíticos para solos beges da região de Casamance no Senegal foi explicado por Chauvel \& Pedro (1978) como sendo devido a um fenômeno de ultradessecação provocado por regimes climáticos muito contrastantes que provocam o rompimento das ligações ferro-argila dos solos ferralíticos e uma posterior redistribuição do material, iluviação e obstrução dos poros para formar solos com estrutura compacta e maciça ("sols beige").

Numa topossequência em Itatiba (SP), Moniz \& Buol (1982) e Moniz et al. (1982) observaram que a relação Oxissolo-Ultissolo é controlada por mudanças na morfologia do relevo da área. À medida que a vertente se forma, devido ao aprofundamento do nível de base, o processo de fluxo lateral de água começa a funcionar. Como conseqüência, os solos perto da superfície sofrem compressão devido a ciclos alternados de umedecimento com saturação e dessecação o que vai resultar na formação de horizonte argílico com estrutura em blocos e densidade do solo maior. Para explicar a ocorrência de minerais menos intemperizados nas posições mais baixas da vertente, os autores sugeriram a ocorrência de um processo de ressilicatização formando minerais de argila, contrabalanceando o processo de alitização.

A formação de horizonte Bt a partir do horizonte Bw é explicada por Fedoroff \& Eswaran (1985) como sendo resultado da translocação e deposição de argila em horizontes Bw. O processo começaria com uma compactação dos agregados do horizonte $\mathrm{Bw}$, posteriormente a argila se depositaria na forma de argilãs cobrindo estes agregados e preenchendo os poros de empilhamento. Esta compactação começa nos horizontes superficiais; depois, progressivamente, os agregados aumentam de tamanho, se fundem, se aprofundam e depois, consequentemente, a abundância de argilãs aumenta.

Miklós $(1992 ; 1995)$ verificou que a transformação da estrutura microagregada, característica dos Latossolos, em estrutura poliédrica, característica dos horizontes argílicos, foi devida às altemâncias dessecação/retração e umedecimento/expansão que ocorreram em climas mais secos e contrastantes que os atuais provocando a compactação 
da estrutura microagregada. Posteriormente teria ocorrido a iluviação da argila, preenchendo os espaços porosos, seguida de uma fissuração provocada pela retração do material. Atualmente, segundo este autor, está acontecendo o desaparecimento do horizonte com estrutura poliédrica formando uma zona de transição com presença de agregados poliédricos e microagregados, ora poliédricos ora ovais. Estes últimos são formados pela intensa fissuração atual, formando cavidades irregulares, e pela intensa bioturbação, respectivamente.

Vidal Torrado \& Lepsch (1993) estudando uma topossequência sobre migmatitos em Mococa (SP) concluíram que os responsáveis pela transição Bw/Bt foram os processos de adensamento e argiluviação. Estes dois processos foram ocasionados pela ação do fluxo lateral de soluções favorecendo a formação de agregados maiores e mais estáveis e a translocação e deposição de argilas. O processo de argiluviação também foi favorecido pelo material de origem menos intemperizado no sopé.

Em uma área no distrito de Tupi, Piracicaba (SP), Vidal-Torrado (1994) e VidalTorrado et al. (1995) observaram que a transição entre horizontes Bw e Bt foram propiciadas por uma mudança na dinâmica da água na vertente devido ao entalhamento da superfície geomórfica mais antiga. Isto provocou o aparecimento do fluxo lateral da água favorecendo o adensamento subsuperficial do Latossolo e consequentemente a mudança dos fluxos de circulação interna, que se faz de foma concentrada nas paredes dos agregados poliédricos, favorecendo novamente o transporte de argilas. A argiluviação foi um processo importante, obstruindo parcialmente a porosidade, provocando o hidromorfismo temporário e com isso a remoção de ferro e favorecendo o transporte da argila. A argiluviação também promoveu a ligação entre microagregados favorecendo a formação de agregados maiores.

Até agora foram citados trabalhos que estudaram a transição espacial entre horizonte Bw para horizontes Bt. Existem vários trabalhos que estudam a transição Bt para $\mathrm{Bw}$. 
Stoops (1968) explicou que a transição entre um Ultissolo e um Oxissolo envolve a degradação do horizonte argilico. Segundo Fedoroff \& Eswaran (1985), a parte superior do horizonte argílico perde a maior parte dos argilãs, sendo alguns deles retidos em algumas áreas ou incorporados ao fundo matricial. Para eles, os processos de pedoturbação são responsáveis pela homogeneização do material do solo e isto pode ser verificado pela presença de pedotúbulos, agrotúbulos e biotúbulos na parte superior do horizonte argílico.

Pedro et al. (1976) mostraram a formação de uma Terra Roxa Legítima (Latossolo Roxo) a partir de uma Terra Roxa Estruturada. Eles dividiram o processo em cinco estágios: no primeiro, parte-se de um plasma formando uma massa contínua; no segundo, processos de expansão e contração ocorrem e desenvolvem uma rede de fissuras permitindo a circulação de água e ar; no terceiro, essa circulação de água elimina progressivamente cátions e, ao mesmo tempo, os elementos de transição presentes nos óxidos de ferro, resultando numa evolução das formas de ferro nas proximidades das fissuras que provoca uma grande opacidade das periferias; no quarto, a evolução continua no córtex e a microestrutura se transforma dando origem progressivamente a uma porosidade "contornada"; finalmente esta transformação ocorre em todo o material formando a estrutura microagregada. Forma-se assim uma estrutura em "pó de café" que corresponde ao LR que é muito evoluído.

Em uma seqüência TRE --> LR em Ribeirão Preto (SP) Carvalho et al. (1982) concluíram que na TRE, localizada na meia encosta, a formação de microagregados era inibida pela abundância de sílica e bases contida neste perfil. A sílica e bases chegavam por iluviação recente de material intemperizado de basalto. No LR os microagregados estão caracterizados pela abundância de separações plásmicas. Os autores interpretaram que a formação destes foi resultado da tensão e pressão provocadas pela expansão e contração do material.

\subsection{Estrutura e dinâmica da água do solo}


Uma fração importante da água que cai sobre a superfície do solo (precipitações. água de irrigação) transita pelo solo através dos processos de infiltração. de redistribuição, de evaporação e de drenagem. Assim, a cobertura pedológica é um compartimento essencial do ciclo da água na escala de microbacia. Paradoxalmente. o papel do solo no ciclo da água tem sido, há muito tempo, ignorado (considerado como uma "caixa preta") ou simplificado pelos hidrólogos. Merot (1993) citou várias razões para explicar esta problemática: a complexidade da organização da cobertura pedológica, a sua variabilidade no tempo e no espaço, a fugacidade de certos processos que ocorrem em períodos de crise (eventos chuvosos fortes-saturação do solo) e a falta de conceitos ou de ferramentas que permitam trabalhar em escala de microbacia.

Assim os estudos que incluem a dinâmica da água do solo na escala de unidade de paisagem, relativamente numerosos em hidrologia de vertentes (Ruprecht $\&$ Schofield, 1990a; Ruprecht \& Scofield, 1990b; Ritsema et al., 1996), não abordam especificamente as relações existentes entre a organização da cobertura pedológica e a sua dinâmica da água na mesma escala espacial.

$\mathrm{Na}$ Ciência do Solo, a evolução dos conceitos e dos métodos na análise de solos nas últimas três décadas (Ruellan, 1970; Bocquier. 1971; Boulet. 1974; Nahon. 1976; Boulet et al, 1982; Ruellan et al. , 1989; Ruellan \& Dosso, 1993), levou a uma intensificação e aperfeiçoamento da análise estrutural da cobertura pedológica. Esta metodologia permite ter um conhecimento preciso e em escala grande da estrutura interna da cobertura pedológica (geometria dos volumes pedológicos diferenciados, transições entre estes volumes e a distribuição espacial destes volumes). O conhecimento da cobertura pedológica permite entender o papel da organização da cobertura pedológica na dinâmica da água das unidades de paisagem. É assim que os primeiros trabalhos neste tema começaram (Guehl, 1984; Andrieux et al. 1986; Lucas et al., 1986; Grimaldi \& Boulet, 1989). 
Os estudos sobre a estrutura do solo são numerosos. Letey (1991) cita que se. para os morfólogos do solo, as preocupações que motivam o estudo da estrutura (morfologia) do solo são essencialmente de ordem pedogenética, a maior parte dos outros pesquisadores da Ciência do Solo se interessam sobretudo nas relações entre a estrutura do solo e certos processos como as transferências hídricas e gasosas, em outras palavras, na funcionalidade da estrutura do solo.

Em efeito, a estrutura do solo parece ser o principal fator que controla vários processos dentro do solo, em particular os processos de transferência da água. Robain \& Curmi (1986) mostraram, por exemplo, que para dois horizontes pedológicos caracterizados pelos mesmos constituintes mas apresentando estruturas muito contrastadas. as curvas de retenção apresentavam formas bem diferenciadas. Grimaldi \& Boulet (1989) mostraram que os principais horizontes das solos da Guiana, bem diferenciadas do ponto de vista estrutural, apresentaram comportamentos hidrodinâmicos específicos.

Sabemos agora que o comportamento hidrodinâmico de um solo esta intimamente ligado à sua estrutura. No entanto a maior parte dos trabalhos que trataram das relações entre estrutura e comportamento hidrodinâmico de solos tem sido realizados a uma escala espacial compatível com as determinações no laboratório, por exemplo sobre amostras de tamanho centimétrico a decimétrico (Anderson \& Bouma, 1973; Robain \& Cumi. 1986; Grimaldi \& Boulet, 1989; Schuh \& Cline, 1990; Tamari, 1994; Hallaire et al., 1997). Se os estudos que implicam na dinâmica da água na escala de unidade de paisagem são relativamente numerosos, principalmente em hidrologia de vertentes (Ruprecht \& Schofield, 1990a,b; Ritsema et al., 1996), aqueles que abordam especificamente as relações existentes entra a organização da cobertura pedológica e a sua dinâmica da água nesta mesma escala espacial são menos numerosos e as vezes limitados à dinâmica sazonal da água no solo (Guehl, 1984; Andrieux et al., 1986; Lucas et al., 1986). Quando estes estudos ocorrem na escala do evento chuvoso, normalmente acontecem em condições de 
intensidades fortes de precipitação e de volumes elevados de água (Ritsema et al.. 1996; Molicova et al., 1997).

\subsection{Estudos quantitativos da estrutura do solo}

A necessidade da imagem nos estudos da estrutura do solo foi rapidamente percebida pelos micromorfologistas que desenvolveram metodologias originais e um vocabulário abundante para a descrição da estrutura do solo (Kubiena, 1938; Stoops \& Jongerius, 1975; Brewer, 1976; Bullock et al., 1985). O estudo da estrutura do solo pelos métodos micromorfológicos, originalmente qualitativos, ganharam uma dimensão quantitativa com o desenvolvimento de métodos de morfologia matemática (Serra. 1982; Horgan, 1998) e do desenvolvimento da informática.

Muito utilizada na pedologia, a noção de estrutura do solo encontra-se no entanto longe da unanimidade quanto à sua definição (Brewer, 1976; Bullock et al.. 1985; Colleuille, 1993). Isto ocorre pelo fato que a noção de estrutura do solo se reveste de várias facetas, mais ou menos priorizadas segundo o centro de interesse do pesquisador, a sensibilidade de sua técnica de estudo da estrutura do solo e à escala de pesquisa adotada.

Uma das definições desta palavra faz referência ao horizonte pedológico. Assim, pode-se definir a estrutura de um horizonte como sendo a forma segundo a qual as partículas elementares (areia, silte, argila, matéria orgânica) se arranjam naturalmente formando ou não volumes elementares macroscópicos chamados agregados (ou "peds" ou "elementos estruturais" ou unidades estruturais"). A este nível de organização do horizonte fala-se de macroestrutura do solo (Zida. 1998).

Mas a noção de estrutura do solo é aplicável a uma gama muito grande de escalas espaciais, desde a assembléia das partículas de argila até as grandes unidades pedológicas em escala d paisagem. Brewer (1976) propus uma definição da estrutura do solo que seria aplicável a qualquer nível de organização do solo considerado. Para este autor, a estrutura 
de um solo é a sua "constituição física expressa pelo tamanho, forma e arranjo das partículas sólidas e de vazios, incluíndo as partículas primárias e as partículas secundárias". Ele definiu também os conceitos de "soil fabric" que é o arranjo espacial dos elementos sólidos e de vazios associados.

Assim definido, a estrutura do solo pode ser formalizado como sendo (McBratney et al., 1992)

$$
T=P \cup S
$$

aonde $T$ é o conjunto representando um volume de solo em um instante dado, $P$ e $S$ dois subconjuntos de $T$ representando o espaço poral e a fase sólida, respectivamente. Pode-se adotar as terminologias "estrutura de vazios do solo" e "estrutura de sólidos do solo" como proposto por Fox \& Teakle (1963), o que permite excluir toda a ambiguidade da noção de estrutura do solo. De fato, são as duas facetas de uma mesma realidade.

Uma implicação prática, para a medida da estrutura do solo, da distinção introduzida acima de entre estrutura do espaço poral e estrutura dos sólidos do solo é que pode-se quantificar a estrutura do solo seguindo duas vias diferentes:

- com base no espaço poral, geralmente o caso da técnica de análise de imágens de uma lâmina delgada de solo (Ringrose-Voase, 1991);

- com base na fase sólida (Colleuille \& Bradeau, 1996).

Vários autores tem utilizado a análise de imagens para quantificar a estrutura do espaço poral sobre lâminas delgadas de solo (Jongerius et al., 1972; Murphy et al.. 1977a,b; Pagliai et al., 1984; Ringrose-Voase, 1990; Ringrose-Voase \& Nys. 1990; Hallaire, 1994; Bruand et al., 1996). Um dos maiores interesses desta técnica é que ela permite uma caracterização morfológica do espaço poral. As medidas da estrutura do espaço poral que ela permite são mono- ou bidimensionais (Zida, 1998). É no entanto possivel se estimar parâmetros tridimensionais a partir de medidas utilizando a estereologia (Weibel, 1980) se os modelos geométricos apropriados são disponíveis (Ringrose-Voase \& Nortcliff, 1987), ou por reconstrução a partir de cortes seriados (Dullien, 1991; Cousin, 
1996). Mas como ressalta Dexter (1988), mais trabalhos de pesquisa e de desenvolvimento restam ser feitos antes de que se possa quantificar de forma rotineira a estrutura do solo. Em todo caso, as medidas bidimensionais fornecem parâmetros do espaço poral úteis para fins puramente descritivos mas susceptiveis de serem ligados às características funcionais do solo (Zida, 1998). 


\section{MATERIAL E MÉTODOS}

\subsection{Localização e caracterização do meio físico}

A área de estudo encontra-se no Campus da USP em Piracicaba, centro-leste do Estado de São Paulo, ao norte do Trópico de Capricórnio. Situa-se nas coordenadas 22 44' de latitude sul e $47^{\circ} 33^{\prime}$ de longitude oeste (Figura 1 e Figura 2).

Geologicamente, a área situa-se num topo de interflúvio formado pelo Rio Piracicaba sobre depósitos neocenozóicos predominantemente arenosos correlatos da formação Rio Claro, que se assentam sobre os sedimentos do Permiano Inferior da formação Iratí. Tal estratigrafia é interrompida no local de estudo por uma intrusão de rocha básica hipobissais (diabásio) na forma de um grande sill, relacionado a formação Serra Geral, do Jurássico/Cretáceo que, após fases erosivas do passado, acabou por ser exposto pelo entalhamento do vale, sendo o material de origem de parte dos solos estudados. Um depósito argiloso vermelho do Quaternário, separado por uma linha de pedras, recobre o sill e parte da formação Iratí , que é encontrado numa posição mais elevada no contato com a borda do sill (Cooper, 1996).

Geomorfologicamente, a área situa-se na Zona do Médio Tietê, da província da Depressão Periférica. Predominam nesta zona relevos de colinas amplas e colinas médias (IPT, 1981). Segundo Penteado (1968), o quadro morfológico mais característico é o de amplitude de horizontes e suavidade de formas, formando colinas de topo aplainado entre 550 e $650 \mathrm{~m}$, levemente convexas, divisoras de vales largos, rematados em fundo chato de planícies aluviais. Apesar de dominarem os sedimentos paleozóicos, ocorrem áreas superficiais descontínuas de corpos intrusivos magmáticos, geralmente na forma de sills e diques de diabásio que desempenham papel importante na topografia. 


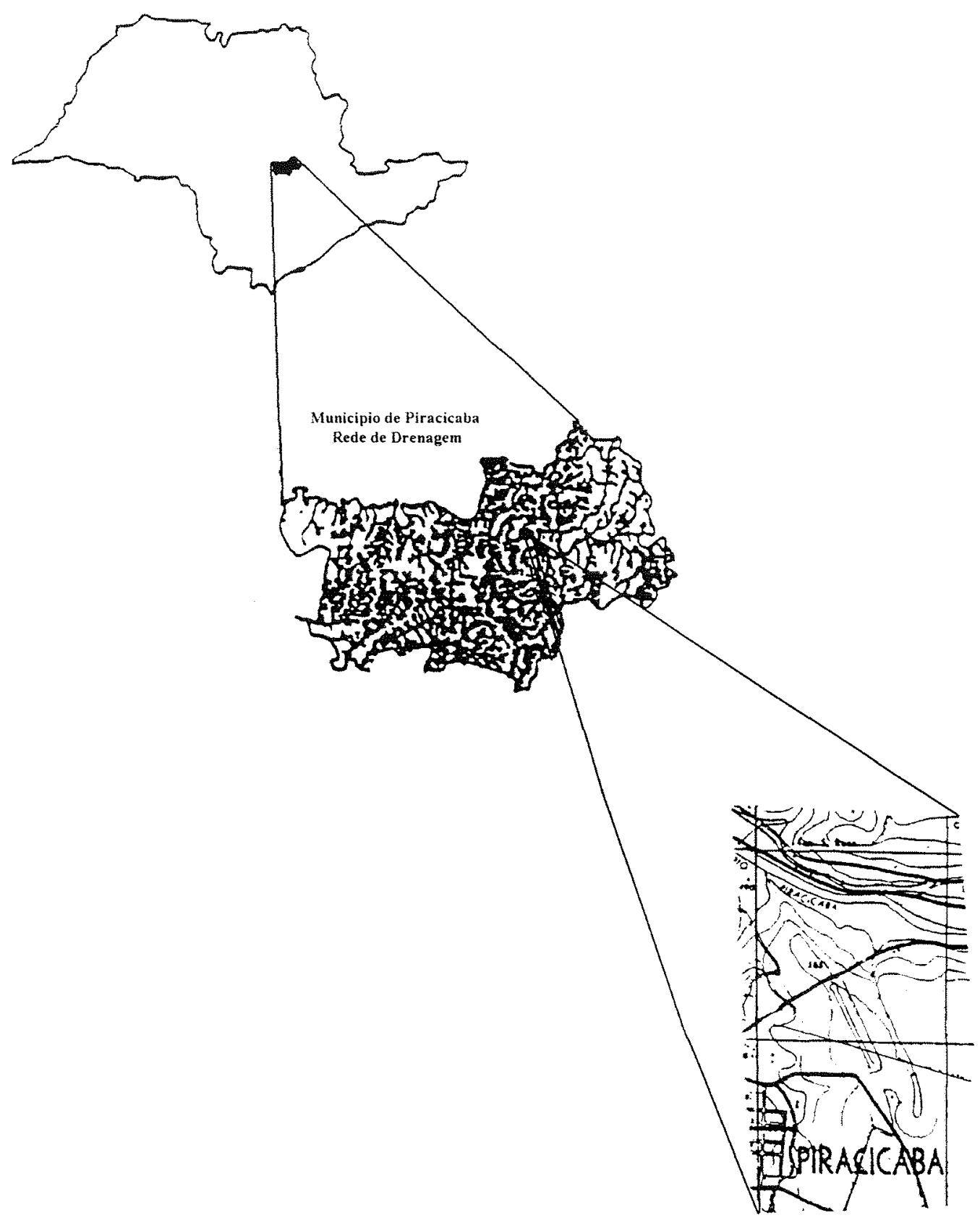

Figura 1: Localização da área estudada no Estado de São Paulo. 


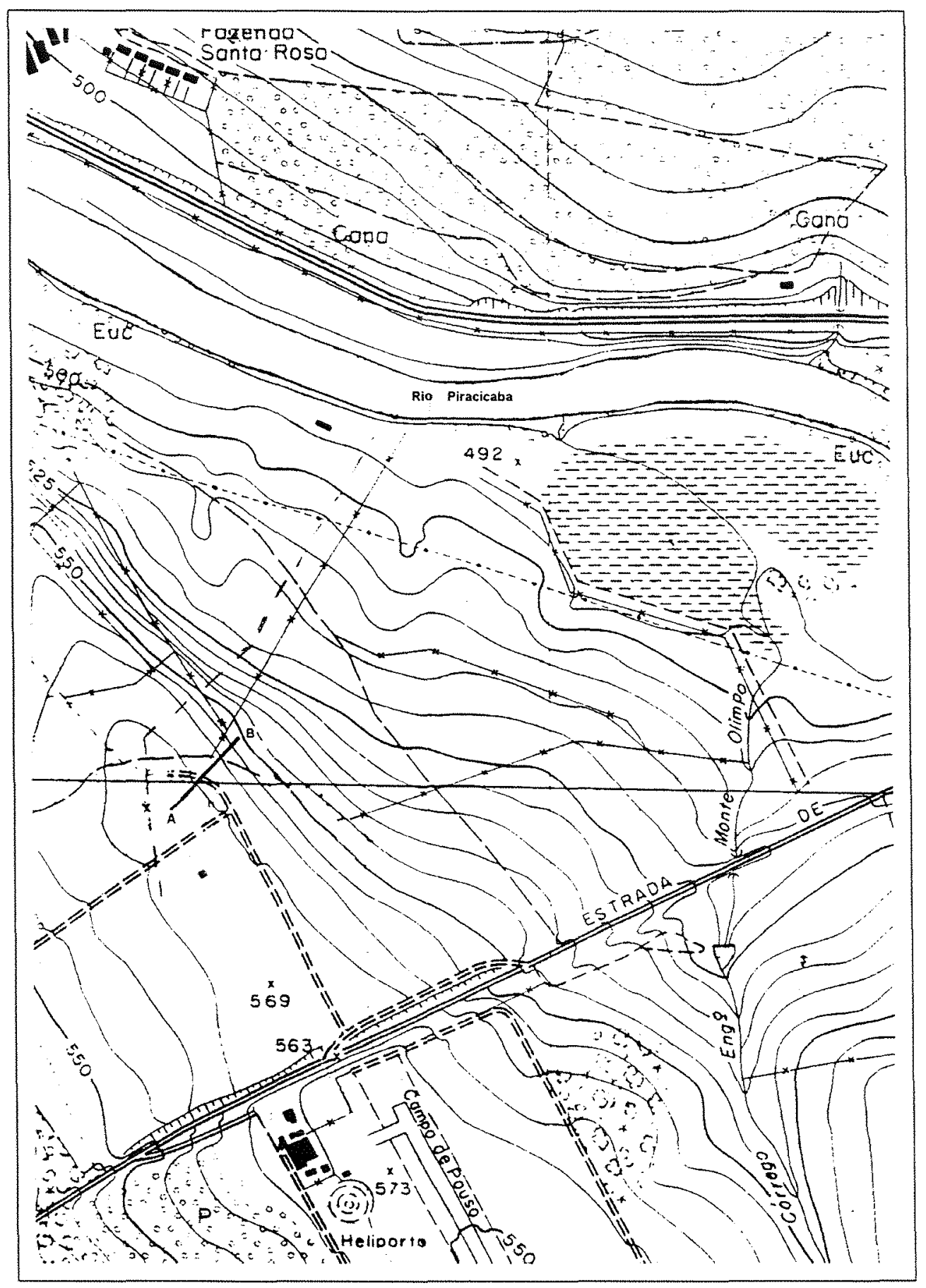

N

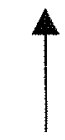

$100200 \mathrm{~m}$

Figura 2 Mapa planialtimétrico da área estudada mostrando a posição da sequência estudada (Corte A, B). 
O clima da região de Piracicaba, é classificado no sistema Koppen como Cwa, isto é mesotérmico úmido subtropical de inverno seco, em que a temperatura do mês mais frio é inferior a $18^{\circ} \mathrm{C}$ é a do mês mais quente ultrapassa os $22^{\circ} \mathrm{C}$ (Comissão de Solos, 1960). O regime térmico dos solos é hipertérmico (Oliveira et al., 1976). O total de precipitação para os meses de inverno é de $101 \mathrm{~mm}$. Janeiro é o mês mais úmido, com uma média de $217 \mathrm{~mm}$, sendo o total para os meses mais úmidos (dezembro, janeiro, fevereiro) de $619 \mathrm{~mm}$ (Figura 3).

A cobertura vegetal natural da área pertenceu ao subtipo floresta latifoliada tropical (Ranzani et al., 1966). Atualmente a área e utilizada para a explotação intensiva de bovinos e esta coberta por pastagem (Brachiaria decumbens).

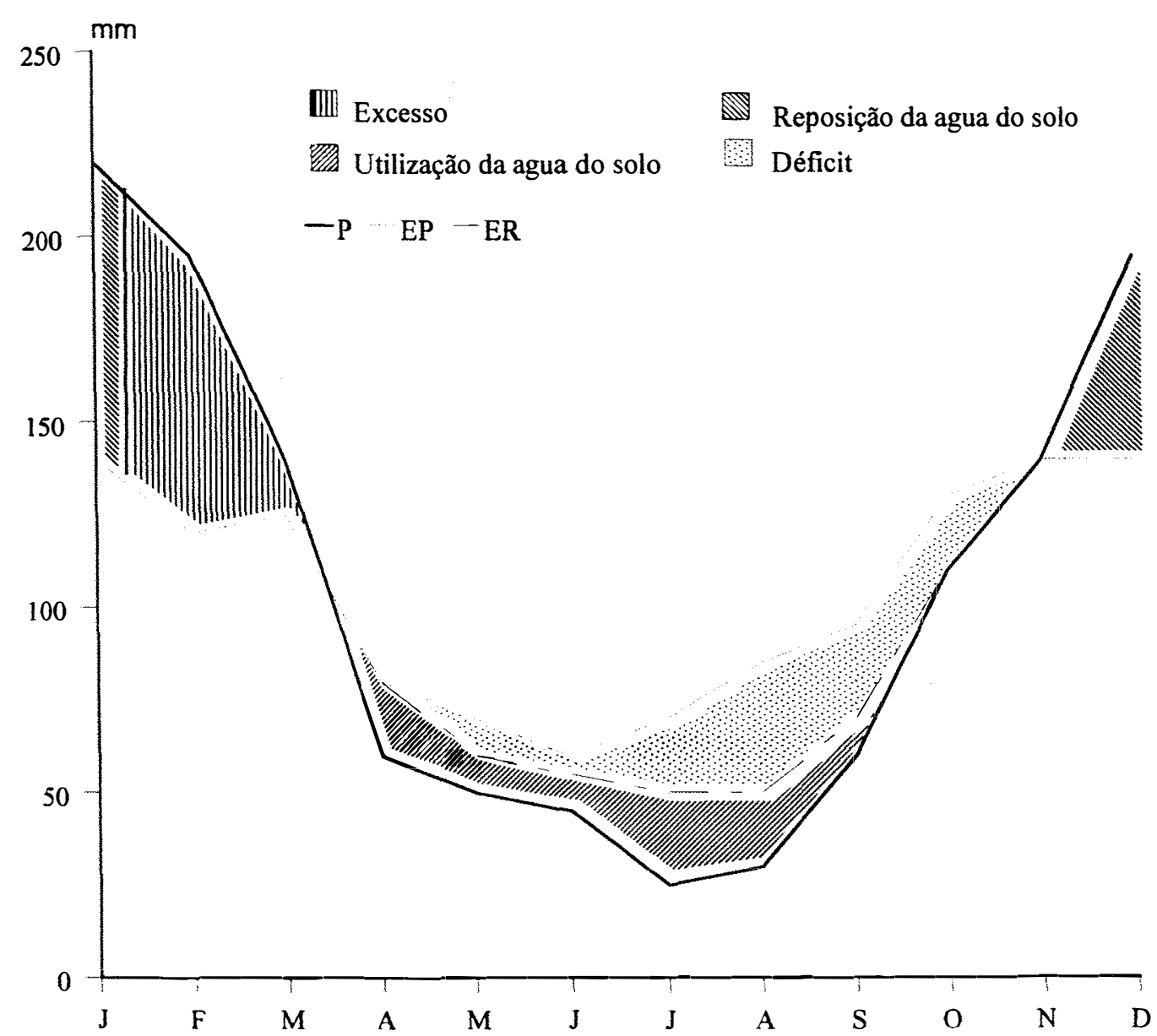

Figura 3: Balanço hídrico da região de Piracicaba. $(\mathrm{P}=$ precipitação; $\mathrm{EP}=$ evapotranspiração potencial; ER= evapotranspiração real)

\subsection{Solos}




\subsection{Solos}

O mapa de solos da área estudada (Figura 4) foi realizado por Vidal-Torrado et al. ${ }^{2}$ (1993), e apresenta os seguintes solos:

TRL $\rightarrow$ Terra Roxa Estruturada Latossólica Eutrófica, A moderado, textura argilosa/muito argilosa (Kandiudalfic Eutrudox).

TR1 $\rightarrow$ Terra Roxa Estruturada Eutrófica, A moderado. textura argilosa/muito argilosa (Kandiudalfic Eutrudox).

TR3 $\rightarrow$ Terra Roxa Estruturada Eutrófica Pouco Profunda, A moderado, textura argilosa/muito argilosa (Kandiudalfic Eutrudox).

TR4 $\rightarrow$ Associação de Terra Roxa Estruturada Eutrófica pouco profunda, A moderado ou chernozêmico, textura argilosa, fase pedregosa (Rhodic Kandiudalf) + Terra Roxa Estruturada Eutrófica, A moderado, textura argilosa (Rhodic Kandiudalf) + Cambissolo Eutrófico. A moderado ou chernozêmico, $\mathrm{Tb}$, textura argilosa, substrato diabásio (Typic Eutrochrept).

BV2 $\rightarrow$ Associação Brunizem Avermelhado, textura argilosa, substrato diabásio (Typic Argiudoll $)+$ Terra Roxa Estruturada intermediária para Brunizem Avermelhado (Typic Hapludoll) + Terra Roxa Estruturada Eutrófica, textura argilosa/muito argilosa (Rhodic Kandiudalf).

B $\rightarrow$ Associação de Brunizem textura argilosa, substrato diabásio (Typic Argiudoll) + Brunizem Vértico, substrato diabáiso (Vertic Argiudoll) + Vertissolo (Typic Chromudert) com inclusões de Plintossolo Vértico (Plintaquept).

$\mathrm{Al} \rightarrow$ Solo Aluvial Eutrófico, Tb, textura média/arenosa (Typic Udifluvent).

G1 $\rightarrow$ Gleissolo Eutrófico, A chernozêmico, textura média a argilosa (Humic Haplaquept).

G2 $\rightarrow$ Gleissolo Eutrófico, A moderado, textura argilosa/argilosa ou média/média a argilosa (Typic Haplaquept) com inclusões de solos vérticos (Vertic Haplaquept).

${ }^{2}$ VIDAL-TORRADO, P.; SPAROVEK, G.; COOPER, M.; OLIVEIRA, M.C. de \& VILAS BOAS DO PRADO, G. Mapa pedológico detalhado do Campus "Luiz de Queiroz".Escola Superior de Agricultura "Luiz de Queiroz". 1993.Não publicado. 


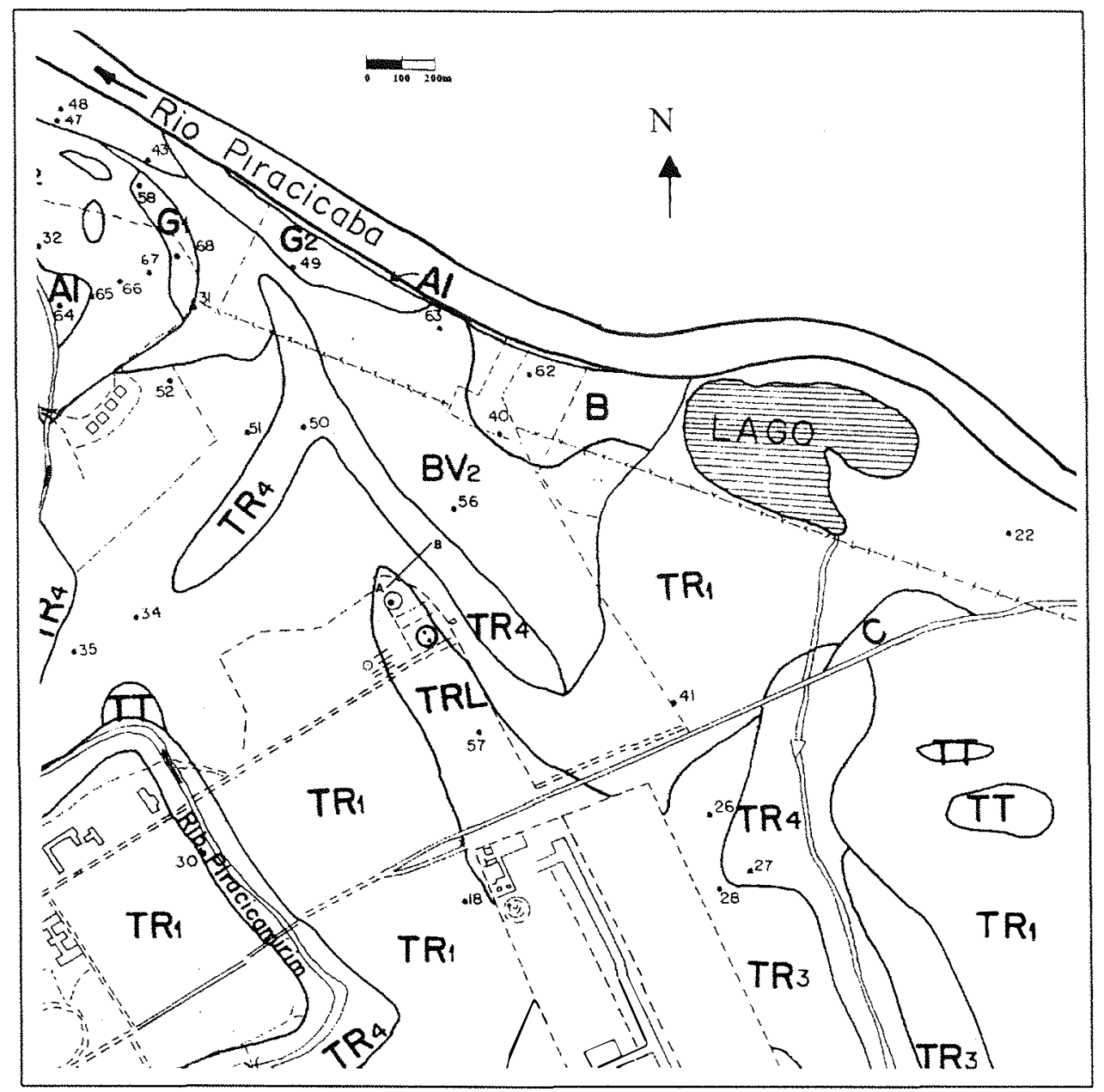

\begin{tabular}{|c|c|}
\hline Legenda & Solo \\
\hline TRL & Tetra Roxa Estruturada Latossólica Eutrófica. A moderado, textura argilosa/muito argilosa (Kandiudalfic Eutrudox). \\
\hline TRI & ena Roxa Estruturada Eutrófica, A moderado, textura argilosa/muito argilosa (Kandiudalfic Eutridox). \\
\hline TR3 & Terra Roxa Estruturada Eutrófica Pouco Profunda. A moderado. textura argilosavmuito argilosa (Kandiudalfic Eutrudox \\
\hline TR4 & $\begin{array}{l}\text { Associaçào de Tema Roxa Estruturada Eutrófica pouco profunda, A moderado ou chemozémico. textura argilosa, fase pedregosa } \\
\text { (Rhodic Kandiudalf) + Terra Roxa Estruturada Eutrótica. A moderado, texnura argilosa (Rhodic Kandiudalt) }\end{array}$ \\
\hline BV2 & $\begin{array}{l}\text { Associaçào Brunizem Avermellhado, textura argilosa, substrato diabásio (Typic Argiudoll) + Terra Roxa Estruturada intennediária } \\
\text { para Brinizem Avennellhado (Typic Hapludoll) }\end{array}$ \\
\hline$\overline{\mathrm{B}}$ & $\begin{array}{l}\text { Associaçào de Brunizem textura argilosa, substrato diabasio (Typic Argiudoll) + Brumizem Vético. substrato diabáiso (Ventic } \\
\text { Argiudoll) + Vertissolo (Typic Chromudert) com inclusōes de Plintossolo Vértico (Plintaquept). }\end{array}$ \\
\hline GI & Gleissolo Eutrófico, A chemozènico, textura média a argilosa (Hunic Haplaquept). \\
\hline G2 & $\begin{array}{l}\text { Gleissolo Eutrófico, A moderado. textura argilosa/argilosa ou média/média a argilosa (Typic Haplaquept) com inclusòes de solos } \\
\text { vérticos (Vertic Haplaquept). }\end{array}$ \\
\hline Al & Solo Aluvial Eutrótico. To. textura média/arenosa (Typic Udifluvent). \\
\hline TT & Afloramento da rocha \\
\hline
\end{tabular}

Figura 4: Mapa pedológico semi-detalhado (Vidal-Torrado et al. ${ }^{2}$. 1993) mostrando a posição da sequência estudada (Corte $\mathrm{A}, \mathrm{B}$ ). 


\subsubsection{Análise estrutural da topossequência}

Para o detalhamento maior da vertente foi realizado um estudo bidimensional da configuração lateral dos diferentes horizontes seguindo metodologia proposta por Boulet et al. (1982) e Boulet (1988). Comparou-se a morfologia dos horizontes dentro da transeção e a partir destas observações, desenhou-se toda a sequência vertical e lateral dos horizontes, permitindo a visualização desta em corte longitudinal desde o topo até o dique marginal (Figura 5).

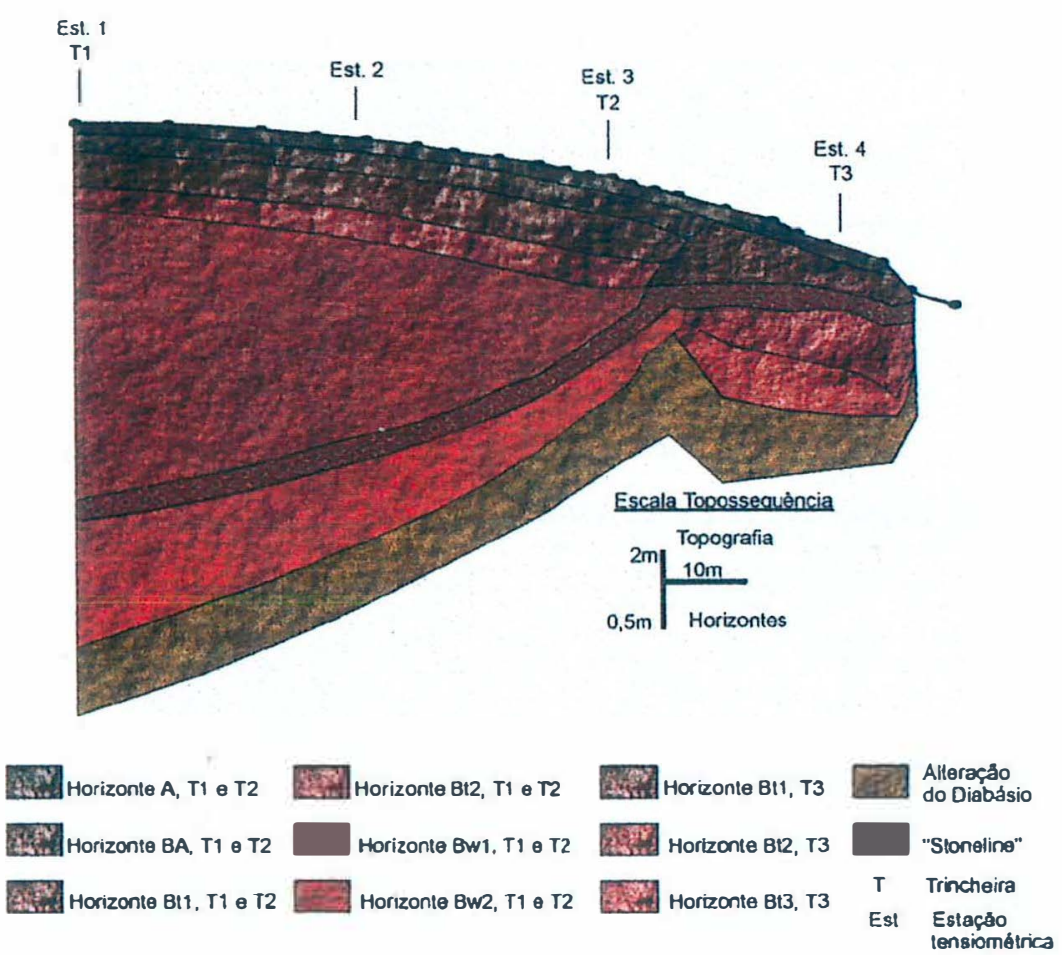

Figura 5: Disposição dos horizontes na topossequência estudada. 


\subsection{Estabelecimento dos locais de amostragem e amostragem dos solos}

Conhecidos os segmentos da vertente e visando estudar a transição existente entre os horizontes $\mathrm{Bw}$ e $\mathrm{Bt}$, foram abertas 3 trincheiras no topo, ombro e começo da meia encosta onde estas feições se apresentavam mais caracterizadas.. No topo, um número variável de tradagens profundas (ate $7 \mathrm{~m}$ ) foi realizada para o estudo da uniformidade do material seguindo a metodologia da análise estrutural proposta por Boulet et al. (1982).

Nas trincheiras foram feitas descrições morfológicas seguindo as normas do Manual de Descrição e Coleta de Solos no Campo (Lemos \& Santos, 1984), coletadas amostras para análises granulométricas e químicas de rotina e mineralógicas por difração de Raios X, amostras indeformadas para a determinação da densidade do solo e da curva de retenção de cada horizonte e amostras indeformadas e orientadas para análise micromorfológica e de microscopia eletrônica de varredura.

\subsection{Análise das amostras de solo}

\subsubsection{Análise granulométrica das amostras de solo}

As análises granulométricas das amostras coletadas em trincheiras e tradagens foram feitas nos laboratórios do Departamento de Solos e Nutrição de Plantas da ESALQ/USP. Após agitação horizontal por 16 horas, foi feita a separação das frações granulometricas da TFSA (terra fina seca ao ar) pelo método do densímetro, utilizando-se como dispersante solução contendo hidróxido de sódio e hexametafosfato de sódio (Camargo et al., 1986).

\subsubsection{Análises químicas de rotina}

Essas determinações seguiram as metodologias recomendadas por Raij et al. (1987). 
Para determinação da reação do solo foram medidos $\mathrm{pH}$ em $\mathrm{H}_{2} \mathrm{O}$, em $\mathrm{KCl} 1 \mathrm{M}$ e $\mathrm{CaCl}_{2}$ 0,01M. A matéria orgânica foi determinada após oxidação com dicromato de potássio e titulação com sulfato ferroso amoniacal. Para a determinação do alumínio trocável, utilizou-se $\mathrm{KCl} 1 \mathrm{M}$ como solução extratora. A acidez potencial $(\mathrm{H}+\mathrm{Al})$ foi obtida após extração com acetato de cálcio $1 \mathrm{M}$ a pH 7,0. Cálcio, magnésio, potássio trocáveis e fósforo foram determinados pelo método da resina de troca î̂nica.

\subsubsection{Análise micromorfológica}

Após a descrição morfológica dos perfis, segundo Lemos \& Santos (1984). foram coletadas amostras indeformadas e orientadas dos principais horizontes e das transições entre estes.

\subsubsection{Confecção de lâminas delgadas}

A confecção das lâminas delgadas foi realizada em três etapas:

a) desidratação das amostras: o teor de umidade encontrado nas amostras é função principalmente da presença de água nos poros. Como a água não é miscível com a resina utilizada foi necessário desidratá-las antes de iniciar o processo de impregnação.

A técnica de desidratação empregada, descrita em Bénard (1996), consiste em trocar a água do solo por acetona, líquido miscivel com a resina utilizada. As amostras foram mergulhadas em recipientes com acetona, conectados a uma bomba pneumática, com vazão de $30 \mathrm{~cm}^{3} / \mathrm{mm}$ e a três colunas de zeolitos, formando assim um circuito fechado que em movimento possibilitou a substituição progressiva da água pela acetona sem modificar a estrutura do solo.

b) impregnação das amostras: após a desidratação, as amostras foram impregnadas por capilaridade utilizando-se uma resina poliester não saturada (Crystic SR 17449), adicionada à um pigmento fluorescente (Ciba-Geigy Uvitex OB).

c) confecção das lâminas: depois de endurecidas as amostras foram polidas mecanicamente empregando-se um equipamento denominado "Rectifeuse Plane", 
adaptado à confecção de lâminas pela substituição da sua plataforma magnética por uma outra à pressão. Esta plataforma funciona como suporte para confeccionar seis lâminas de aproximadamente $40 \mu \mathrm{m}$, a cada operação.

Numa segunda etapa, as lâminas foram polidas manualmente utilizando-se um papel abrasivo até obter-se seções delgadas com espessura média de $30 \mu \mathrm{m}$.

Para este estudo foram confeccionadas 30 lâminas de $16 \times 9 \mathrm{~cm}$.

\subsubsection{Descrição e interpretação das lâminas delgadas}

A observação e descrição das lâminas delgadas foi realizada na sala de microscopia do laboratório de Ciência do Solo e Bioclimatologia do INRA-Rennes, França, equipado com um microscópio ótico polarizante Zeiss e uma lupa binocular Wild, ambos sob luz normal e polarizada.

As descrições seguiram os critérios propostos por Brewer (1976), Stoops \& Jongerius (1975) e Bullock et al (1985). Estes procedimentos além de facilitarem a identificação e organização dos constituintes e sua estatística elementar (contagem, distribuição, dimensão, teores relativos, etc.), serviram também como base para a determinação dos critérios de arranjo, tipologia, hierarquia e cronologia entre as diversas organizações micromorfológicas.

A análise micromorfológica compreendeu as seguintes etapas:

a) identificação dos constituintes do fundo matricial (plasma, esqueleto e poros) e sua freqüência aproximada;

b) estudo do sistema poral. Atenção especial foi dada nesta etapa devido a sua importância na escolha de sítios representativos que posteriormente seriam utilizados nos estudos de análise de imagens. Os critérios adotados foram: dimensão, morfologia, e comunicação entre os poros;

c) identificação das estruturas plásmicas e de base e as suas frequências;

d) identificação das feições pedológicas (pedotúbulos, cutãs, nódulos. etc.)

\subsubsection{Análise de imagens}


Este estudo foi realizado no laboratório de Ciência do Solo do INRA-Rennes, França, a partir de uma estação SUN Spark IPC composta de uma carta gráfica Data Cell S2200 e de um programa de análise de imagens Noesis Visilog.

Foram adquiridas, utilizando uma câmera CCD cinco (5) imagens retangulares (8x6 mm) para cada lâmina delgada. numeralizadas em 768 x 576 pixels $\left(100 \mu \mathrm{m}^{2}\right.$ por pixel) com resolução espectral de 256 níveis de cinza. Uma vez feita a aquisição a imagem foi binarizada e logo etiquetada para a realização das quantificações. A operação de etiquetação possibilita reconhecer os poros sobre cada imagem binária através de um critério de conexão. Uma análise individual dos poros sobre as imagens etiquetadas permitiu a caracterização morfológica da macro e mesoporosidade.

\subsubsection{Parametrização das características porais}

Um grande número de parâmetros pode ser utilizado para descrever quantitativamente estrutura do espaço poral (Ringrose-Viase \& Bullock, 1984; Ringrose Voase, 1987; Moran et al., 1988 e Hallaire \& Cointepas, 1993). Estes parâmetros podem ser classificados em dois tipos (Ringrose-Voase, 1991): por um lado os parâmetros da imagem, que se referem ao conjunto do espaço poral na imagem, e, por outro lado, os parâmetros do objeto, que se refere às entidades discretas sobre a imagem.

\subsection{Parâmetros da imagem}

\section{- Porosidade total}

A porosidade total é a estimativa da porosidade de uma imagem (Hallaire \& Cointepas, 1993) obtida da relação entre o número de pixels da fase poral e o número total de pixels da imagem binária.

"A porosidade total é um parâmetro global, insuficiente para descrever quantitativamente o espaço poral. Para ser mais preciso convém afinar a descrição observando como se distribui a porosidade total. 


\subsection{Parâmetros do objeto}

- Noção de poróide

O sistema poral do solo é uma rede tridimensional de poros interconectados. Consequentemente a seção de uma amostra de solo revela, no plano de corte, regiões que aparecem individualizados. Moran et al. (1988) propuseram o termo "poroid" para designar as zonas correspondentes à interseção da rede poral tridimensional com o plano de corte da lâmina.

Os parâmetros do objeto são medidos sobre cada poróide. Isto implica que sobre a lâmina analisada os poróides devem estar individualizados. A operação de etiquetação, no programa Visilog, permite a obtenção desta individualização dos poróides.

- Distribuiçãao em tamanhos dos poróides

A distribuição por tamanhos dos poróides corresponde a uma partição da porosidade total em classes de tamanho definidas pelo aumento constante do logaritmo decimal da superfície dos poróides. O valor deste aumento escolhido conduz a limites de classes de progressão geométrica de razão $\approx 1,78$.

- Índice de forma dos poróides

O índice de forma é um parâmetro que permite dar informações cifradas sobre a forma de um objeto (Coster \& Chermant, 1989). Diferentes índices de forma são utilizados em análise de imagens de solos (Murphy et al., 1977a; Ringrose-Voase \& Bullock. 1984 e Ringrose-Voase. 1996). Foram utilizados dois índices para apreciar a forma dos poróides:

$$
I_{I}=P^{2} /(4 \pi A)
$$

onde $P$ é o perímetro do poróide e $A$ a área que ocupa.

Este índice é igual a 1 para uma forma perfeitamente circular, e é maior a medida que a forma desvia-se do círculo.

O segundo índice de forma é assim definido 
$I 2=\frac{\frac{1}{m} \sum_{i}\left(N_{l}\right) i}{\frac{1}{n} \sum_{i}\left(D_{l:}\right) j}$

onde $m=$ número de direções $i$ nas quais são calculados o número de interceptos $N_{I}{ }^{3}$. ( $i=$ $0^{\circ}, 45^{\circ}, 90^{\circ}$ e $\left.135^{\circ}\right)$

$n=$ número de direções $j$ nas quais são calculados os diâmetros de Féret $D_{F}{ }^{t},\left(j=0^{\circ}\right.$ e $\left.90^{\circ}\right)$

$\mathrm{O}$ índice $I_{2}$ foi utilizado como complementar ao índice $I_{l}$ para afinar as classes de poriódes definidos a seguir.

\section{- Tipologia morfológica dos poróides}

A partir de um jogo de imagens nas quais as principais formas dos poróides podem ser observadas, procede-se a identificação dos poróides como sendo:

- canais, cavidades isoladas, poros tubulares. Esta categoria de poróides apresenta um indice de forma $I_{1} \leq 5$. Ela define a classe morfológica Arr de poróides arredondados (Figura 6).

- poros resultando da assembléia de agregados e/ou de partículas elementares e de poros de diversos tipos interconectados formando, nos dois casos. uma rede poral de tamanho grande de formas muito contornadas. Esta categoria de poróides é caracterizada por um indice de forma $I_{l}>25$. Ela define os poróides de forma complexa (Figura 6).

\footnotetext{
${ }^{3}$ O número de interceptos, $N_{l}$, de um objeto na direção $i$ é o número entradas naquele objeto ao longo de retas paralelas à direção $i$.

${ }^{4}$ O diâmetro de Féret, $D F$, de um objeto numa direção $j$ é a distancia entre duas tangentes paralelas à direção j e enquadrando o contorno do objeto.
} 
Dentro da gama de índices de forma $I_{l}$ compreendido entre 5 e 25 coexistem poróides alongados e poróides de forma complexa, de tamanho menor, em geral. que os precedentes. $\mathrm{O}$ índice $I_{2}$ foi elaborado para separar os limites do índice $I_{l}$ neste caso. Este índice permitiu melhor discriminar os poróides alongados (Alon) (Figura 6) e os poróides complexos (Comp): os primeiros tem um $I_{2} \leq 2,2$ enquanto que os segundos apresentam um $I_{2}>2,2$ (Tabela 1). O limite de 2,2 é evidentemente arbitrário e uma certa taxa, relativamente pequena, de classificação incorreta dos poróides Alon e Comp subsiste.

As três classes de forma assim definidos, i.e. arredondado (Arr), alongados (Alon) e complexos (Comp) foram cruzadas com as classes de tamanho dos poróides na escala utilizada. A Tabela 2 apresenta as classes de tamanho em função da forma, resultado deste cruzamento.

Tabela 1: Definição das classes de forma dos poróides

\begin{tabular}{lcc}
\hline Poróides & \multicolumn{2}{c}{ Indices de forma } \\
& $\mathrm{I}_{1}$ & $\mathrm{I}_{2}$ \\
\hline Arredondados (Arr) & $\mathrm{I}_{1} \leq 5$ & \\
Alongados (Alon) & $5<\mathrm{I}_{1} \leq 25$ & $\leq 2.2$ \\
Complexos (Comp) & $5<\mathrm{I}_{1} \leq 25$ ou $>25$ & $>2.2$ \\
\hline
\end{tabular}

Tabela 2: Definição das classes de tamanho $\mathrm{x}$ forma dos poróides

\begin{tabular}{c|ccc}
\hline $\begin{array}{c}\text { Limites das classes de tamanho } \\
\mathrm{em} \mathrm{m} \mathrm{mm}^{2}\end{array}$ & \multicolumn{3}{|c}{ Classes de forma } \\
& Arredondados & Alongados & Complexos \\
\hline $0,001-0,01$ & $\operatorname{Arr}_{\mathrm{p}}$ & Alon $_{\mathrm{p}}$ & Comp $_{\mathrm{p}}$ \\
$0,01-0,1$ & $\operatorname{Arr}_{\mathrm{m}}$ & Alon $_{\mathrm{m}}$ & Comp $_{\mathrm{m}}$ \\
$>0,1$ & $\operatorname{Arr}_{\mathrm{z}}$ & Alon $_{\mathrm{g}}$ & Comp $_{\mathrm{g}}$ \\
\hline
\end{tabular}




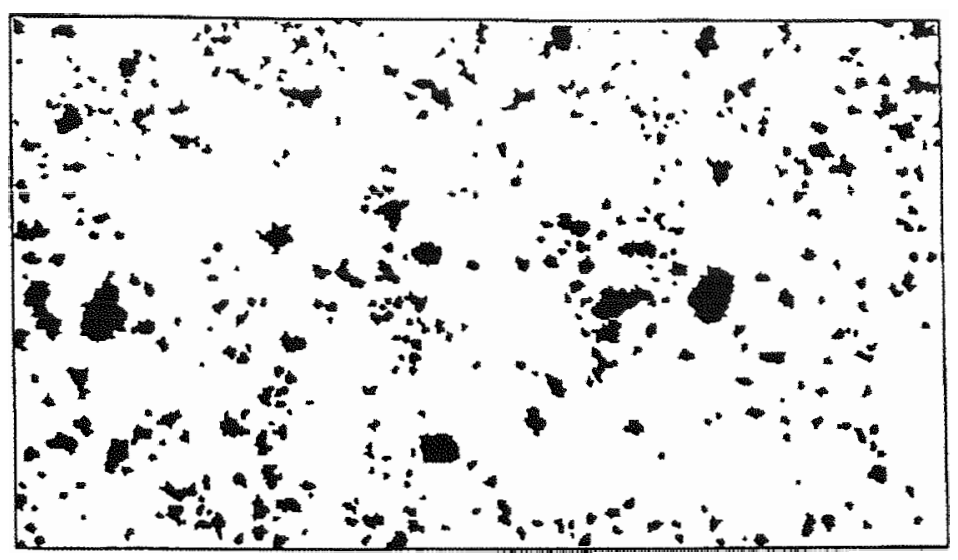

(a)

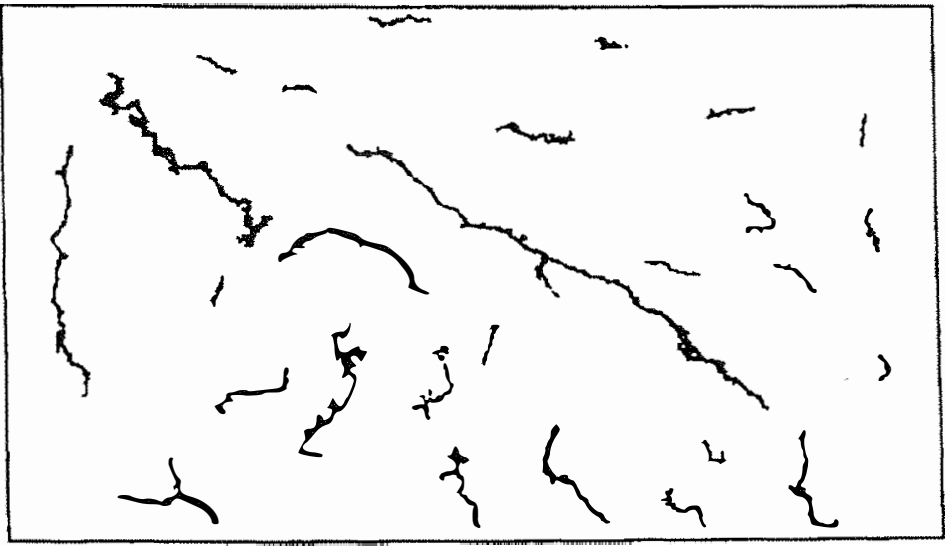

(b)

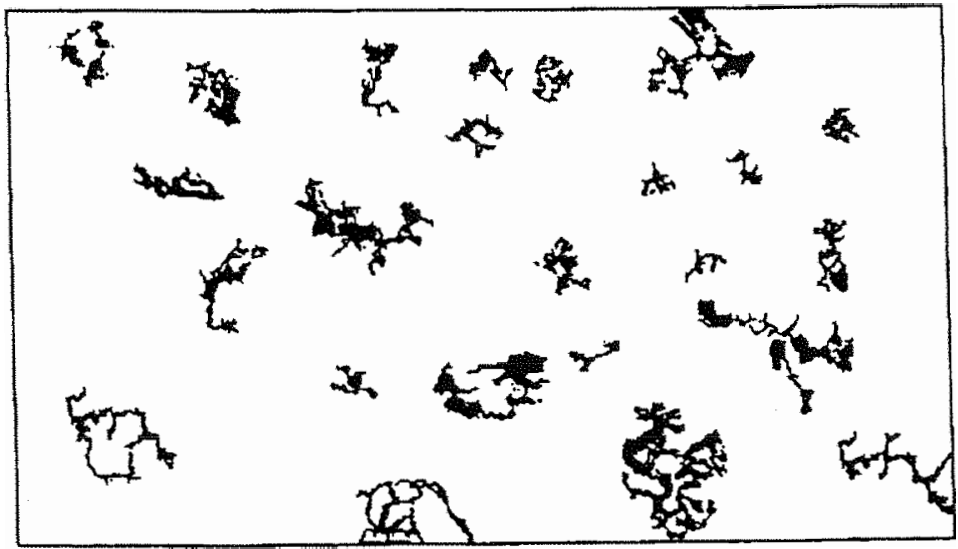

(c)

Figura 6: Exemplos de imagens mostrando poróides representativos classes de forma definidos: (a) Arredondados, (b) Alongados, (c) Complexos. 


\subsubsection{Análises físico e hídricas}

\subsubsection{Densidade do Solo}

A densidade do solo é a razão entre a massa de partículas sólidas e o volume total da amostra do solo. Foram coletadas amostras em cilindros de $100 \mathrm{~cm}^{3}$. Com o volume da amostra pré-estabelecido, o ensaio se limita a determinar o peso da amostra após secagem a $105^{\circ} \mathrm{C}$ por $24 \mathrm{~h}$.

\subsubsection{Curva de retenção da água no solo}

A curva de retenção relaciona o conteúdo de água no solo à energia potencial matricial ( $\left.\Psi^{\prime} m\right)$, que é a força com que a água encontra-se retida no espaço poral do solo.

A determinação dos pares (umidade e potencial mátrico) foram realizados em fase de dessorção em amostras com estrutura conservada. Os potenciais determinados foram 0 , $0,005,0,01,0,03,0,05,0,08,0,1,0,33 \mathrm{kPa}$ e $0,1,0,5,1,5 \mathrm{MPa}$. Os potenciais de $0.005 \mathrm{a}$ $0,1 \mathrm{kPa}$ foram determinados utilizando uma panela de tensão preenchida com areia de granulometria conhecida e constante. Os potenciais de $0,33 \mathrm{kPa}$ a $1,5 \mathrm{MPa}$ foram determinados utilizando câmaras de Richards, conforme método descrito por Klute (1986).

\subsubsection{Tensiometria}

Foram instaladas quatro estações tensiométricas na área de estudo (Figura 5). As quatro estações distribuídas no topo e ombro da área comportavam sete tensiômetros que apresentavam as profundidades de 10,30,60,80,100,120 e $150 \mathrm{~cm}$. Estas profundidades foram escolhidas a partir das descrições morfológicas do solo e representam as profundidades dos principais horizontes e transições da seqüência.

Os dados pluviométricos foram obtidos no posto meteorológico da ESALQ/USP situado a trinta (30) metros do local de estudo.

Dois tipos de medidas foram realizadas durante o período de setembro/1997 até junho de 1998. O primeiro tipo refere-se a medidas diárias dos tensiômetros para a obtenção da variação sazonal do potencial total da água do solo. O segundo tipo refere-se a 
medidas durante os eventos chuvosos com o objetivo de conhecer o funcionamento hídrico do solo antes, durante e depois da chuva. Assim, durante cada evento chuvoso foram registradas as medidas antes da chuva, durante a chuva em intervalos de 15 minutos e depois da chuva em intervalos que variavam de uma hora até seis horas durante um período de até 48 horas após a finalização do evento chuvoso.

\subsubsection{Determinação da condutividade hidráulica}

A condutividade hidráulica foi determinada in situ em condições próximas à saturação utilizando um infiltrômetro multidisco à sucção controlada chamado TRIMS (Triple Rings Infiltrometers at Multiple Suctions). Uma descrição detalhada do aparelho e do seu modo de funcionamento é dada por Vauclin \& Chopart (1992).

\subsection{Teoria}

O princípio da infiltrometria à sucção controlada é baseado nas leis de infiltração tridimensional e axisimétrica. A análise dos dados recolhidos durante os ensaios de infiltrometria com sucção controlada utilizam as equações que descrevem a infiltração da água no solo.

A expressão mais comum utilizada para a estimação das propriedades hidrodinâmicas $\left(\mathrm{K}_{\mathrm{o}}\right.$ e $\left.\mathrm{S}_{\mathrm{o}}\right)$ a partir de dados recolhidos durante ensaios de infiltrometria. é fundamentada sobre a solução analítica da equação de infiltração em regime estacionário proposta por Wooding (1968). Esta mostra que, no caso de um aporte de água saindo de uma fonte circular de raio $r$ colocada sobre a superfície do solo, sob uma pressão efetiva $h_{O}$ (negativa, nula ou positiva), o fluxo superficial de infiltração em regime permanente $q_{\infty}$ pode ser expressa aproximativamente pela seguinte expressão:

$$
q_{\infty}=K_{0}+\frac{4 \phi_{0}}{\pi r}
$$

onde $\phi_{0}\left(\mathrm{~m}^{2} \mathrm{~s}^{-1}\right)$ é o potencial de fluxo matricial definido por (Gardner, 1958): 
$\phi_{0}=\int_{h_{n}}^{\lambda_{n_{1}}} K(h) d h ;-\infty<h_{n} \leq h \leq h_{n} \leq 0$

$K_{0}$ é a condutividade hidráulica à pressão $h_{0}$ tal que $K_{0}=K(h)$; os índices $n$ e o fazem referência às condições iniciais e finais, respectivamente.

Desta forma a equação de Wooding pode ser escrita;

$q(\Psi)=\pi r^{2} K(\Psi)+4 \pi \phi(\Psi)$

O protocolo de cálculo utilizado neste trabalho é o apresentado por Ankeny et al. (1991) que se baseia na equação do Wooding. Este protocolo é simplificado utilizando as medidas obtidos com o infiltrômetro com um disco somente. Mas este protocolo simplificado só permite estimar a condutividade hidráulica $K(\Psi)$.

O fluxo volumétrico $q$ é medido para diferentes valores de $\Psi$ (ou h) com um mesmo disco, num mesmo lugar.

Para $\Psi=\Psi_{0}$, a equação (3) é escrita:

$q\left(\Psi_{0}\right)=\pi r^{2} K\left(\Psi_{0}\right)+4 \pi \phi\left(\Psi_{0}\right)$

Para $\Psi=\Psi_{1}$,

$q\left(\Psi_{l}\right)=\pi r^{2} K\left(\Psi_{1}\right)+4 \pi \phi\left(\Psi_{l}\right)$

Admitindo-se, segundo a hipótese de Philip (1985), que

$A=K(\Psi) / \phi(\Psi)$

é constante, em particular para o intervalo $\left(\Psi_{0}, \Psi_{l}\right)$, neste caso:

$A=K\left(\Psi_{0}\right) / \phi\left(\Psi_{0}\right)=K\left(\Psi_{l}\right) / \phi\left(\Psi_{l}\right)$

Pode-se então escrever as equações (4) e (5), sob a forma:

$q\left(\Psi_{0}\right)=\left(\pi r^{2}+4 r / A\right) * K\left(\Psi_{0}\right)$ 
e

$q\left(\Psi_{1}\right)=\left(\pi r^{2}+4 r / A\right) * K\left(\Psi_{1}\right)$

As equações (6) e (7) podem também ser escritas;

$K\left(\Psi_{0}\right)=q\left(\Psi_{0}\right) /\left(\pi r^{2}+4 r / A\right)$

e

$K\left(\Psi_{1}\right)=q\left(\Psi_{1}\right) /\left(\pi r^{2}+4 r / A\right)$

Ankeny et al. (1991) após simplificação gráfica encontrou que;

$A=2\left(q\left(\Psi_{0}\right)-q\left(\Psi_{l}\right)\right) /\left(\left(\Psi_{0}-\Psi_{1}\right) *\left(q\left(\Psi_{0}\right)+q\left(\Psi_{l}\right)\right)\right)$

Este valor de A, determinado utilizando dois valores de potencial mátrico $\left(\Psi_{0}\right.$, $\left.\Psi_{l}\right)$, é utilizado para calcular $K\left(\Psi_{0}\right)$ e $K\left(\Psi_{l}\right)$ a partir das equações (8) e (9).

Se A é determinado utilizando $\left(\Psi_{0}, \Psi_{1}\right)$ e $\left(\Psi_{1}, \Psi_{2}\right)$, Ankeny et al. (1991) propõem calcular $K\left(\Psi_{l}\right)$ como a média aritmética de $K\left(\Psi_{l}\right)$ com A $\left(\Psi_{0}, \Psi_{l}\right)$ e de $K\left(\Psi_{l}\right)$ $\operatorname{com} \mathrm{A}\left(\Psi_{1}, \Psi_{2}\right)$.

\subsection{Medidas da infiltração}

Quatro potenciais foram aplicados durante as medidas de infiltração: $0,-10 .-35$ e $-100 \mathrm{~mm}$. Utilizou-se um disco com um diâmetro de $80 \mathrm{~mm}$. Um ensaio de infiltração consistiu na aplicação das sucessivas pressões selecionadas num único local, começando pelo mais elevado, e seguindo as variações de altura de água infiltrada em função do tempo até a obtenção de um regime quase estacionário. O fluxo de infiltração $q$ é calculada pela seguinte equação:

$$
q=x \frac{\Delta H}{\Delta t}
$$


onde $\Delta H$ é a variação do nível de água no reservatório durante o tempo $\Delta t$ e $x$ é relação entre seção do reservatório de alimentação e a seção do disco.

Para cada horizonte, os ensaios de infiltração foram repetidos quatro vezes na mesma profundidade e em locais distantes 40 a $50 \mathrm{~cm}$ uns dos outros. O solo foi retirado numa superficie de $2 \mathrm{~m}^{2}$ até a profundidade correspondente ao meio do horizonte em estudo, o solo foi cuidadosamente preparado de maneira a obter uma superficie bem plana e horizontal evitando a compactação. Uma fina camada de areia (alguns milímetros) é colocada entre o solo e a base do infiltômetro para melhorar o contato hidráulico. As medidas foram realizadas na época sem chuva (agosto/1997).

\subsubsection{Microscopia eletrônica de varredura}

Os estudos foram realizados em microscópio eletrônico de varredura Philips XL20, acoplado a um espectrômetro de raios X localizado do Ciência do Solo do INRA/Rennes.

A microscopia eletrônica de varredura (MEV) é uma técnica que permite a observação e caracterização de diferentes tipos de materiais como: mineral, vegetal, animal e produtos agroalimentares, a partir da emissão e interação de feixes de elétrons sobre uma amostra, sendo possível caracterizá-la do ponto de vista de sua morfologia e de sua organização. Com relação à escala de observação, o MEV apresenta um intervalo bastante abrangente, variando da ordem de grandeza do milímetro ao nanômetro. O espectrômetro de raios $\mathrm{X}$ permite a caracterização química de áreas e micro-sítios previamente localizados sobre as amostras.

Para este estudo foram confeccionadas lâminas delgadas de solo de formato pequeno $(4.5 \times 7 \mathrm{~cm})$ a partir dos mesmos blocos utilizados na preparação das lâminas para a observação micromorfológica. Uma análise preliminar foi realizada ao microscópio ótico para a demarcação dos sítios representativos para os estudos de ultra-detalhe da porosidade, organização do material e composição química dos constituintes. 
A aquisição de imagens foi efetuada a partir das lâminas delgadas de solo utilizando-se o microscópio eletrônico de varredura no modo de elétrons retroespalhados e nos aumentos de $166 \mathrm{x}$ e $825 \mathrm{x}$. 


\section{RESULTADOS E DISCUSSÃO}

\subsection{Cobertura pedológica}

\subsubsection{Organização dos solos ao longo do transeto}

O presente estudo restringiu-se aos segmentos topo e ombro da topossequência ilustrada na Figura 5. Foi estudado um transeto de $100 \mathrm{~m}$ de comprimento onde ocorre uma transição gradual entre uma Terra Roxa Estruturada Latossólica e uma Terra Roxa Estruturada. O primeiro solo apresenta uma sequência de horizontes A-Bt-Bw que transicionam para uma sequência A-Bt-C no segundo solo. Dentro do primeiro solo a passagem do horizonte Bt típico (Bt1) para o $\mathrm{Bw}$ se faz de forma gradual passando por dois horizontes de transição o $\mathrm{Bt} 2$ e Bt2/Bw. O própio horizonte $\mathrm{Bw}$ pode ser subdividido em dois devido às diferenças no arranjo dos microagregados. Na Terra Roxa Estruturada observa-se a presença de três horizontes $\mathrm{Bt}$ (Bt1, Bt2 e Bt3) que apresentam, como se verá na próxima seção, variações morfológicas principalmente no que se refere à porosidade e estrutura.

O estudo, seguindo a técnica de análise estrutural proposta por Boulet (1982) mostrou que os horizontes descritos nos perfis apresentam uma ligação entre eles no plano bidimensional. Assim, o horizonte Bt encontra-se em todo o transeto com características similares mas que apresentam pequenas variações laterais que levaram à classificação diferenciada em subhorizontes.

Observa-se na Figura 5 que à medida que avançamos da trincheira 1 para a $3 \mathrm{o}$ horizonte Bw vai se afinando até desaparecer completamente antes de chegar na trincheira 
3. A forma em bisel deste horizonte seria uma primeira evidência da transformação estrutural que ocorre entre este horizonte e os horizontes Bt.

A organização dos solos da cobertura pedológica estudada mostra que a transição da Terra Roxa Estruturada Latossólica para a Terra Roxa Estruturada ocorre de forma gradual e com um afinamento do horizonte Bw até seu completo desaparecimento.

\subsubsection{Características morfológicas dos horizontes}

Foram abertas três trincheiras no transeto estudado, uma no topo uma no início do ombro e a terceira no meio do ombro (Figura 5 e 7), onde foram feitas descrições morfológicas detalhadas.

\section{Trincheira 1 (topo)}

Esta trincheira foi dividida em cinco horizontes: $\mathrm{A}, \mathrm{BA}, \mathrm{Bt} 1, \mathrm{Bt} 2$ e $\mathrm{Bw}$, e classificada como uma Terra Roxa Estruturada Latossólica (Figura 7).

Horizonte A: profundidade $0-10 \mathrm{~cm}$; apresenta estrutura poliédrica média de 2$3 \mathrm{~cm}$ com uma subestrutura também poliédrica menos desenvolvido. Cor 2,5YR 3/3. Textura argilosa. Dentro dos agregados encontram-se partículas de quartzo limpo que não estão associados com a argila. Este horizonte apresenta uma pequena compactação nos primeiros $3 \mathrm{~cm}$ mas que não afeta o desenvolvimento das raizes. Transição gradual.

Horizonte BA: profundidade $10-30 \mathrm{~cm}$; apresenta estrutura poliédrica média e subestrutura poliédrica fina $(2-3 \mathrm{~mm})$ bem desenvolvida. Cor 2,5YR 3/6. Textura argilosa. Predomina a porosidade fissural entre os agregados e observa-se uma porosidade tubular menos desenvolvida que atravessa os agregados. Presença de raízes bem desenvolvidas em todo o horizonte. Transição gradual.

Horizonte Bt1: profundidade $30-70 \mathrm{~cm}$; apresenta estrutura poliédrica de tamanho centimétrico com cerosidade abundante e moderada recobrindo todos os agregados. No topo deste horizonte observa-se a presença de uma subestrutura fina $(2-3 \mathrm{~mm})$ semelhante ao do horizonte BA que desaparece a medida que descemos no horizonte. Os agregados apresentam uma forte coesão. A cerosidade observada foi classificada como sendo 
Perfil 1 (T1)

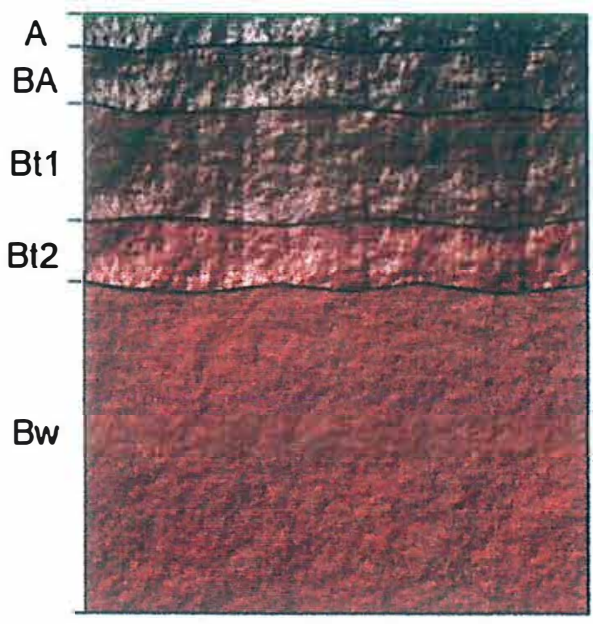

Perfil 3 (T3)

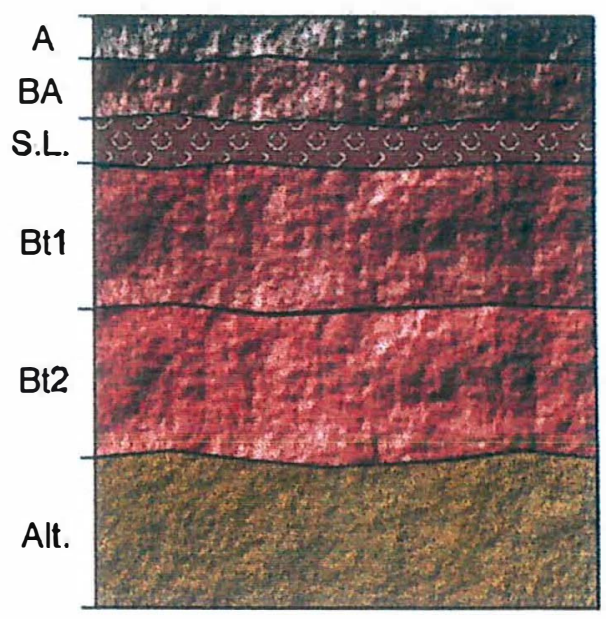

Perfil 2 (T2)

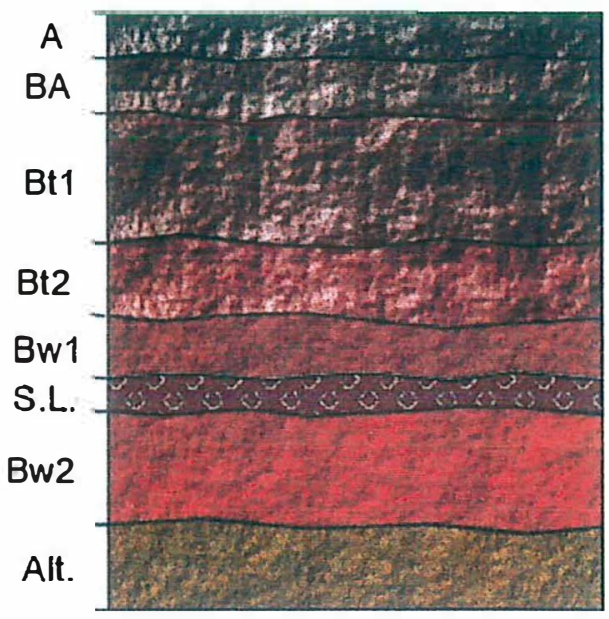

Figura 7: Esquema da disposição dos horizontes nos perfis estudados. 
provavelmente originada por processos de "stress" (stress-cutãs). Cor 2,5YR3 3/4. Textura argilosa. Observa-se a presença de poros tubulares, galerias preenchidas com microagregados e uma porosidade fissural entre os agregados. Dentro das galerias preenchidas com microagregados encontrou-se nódulos argilosos densos de tamanho centimétrico. Raízes se desenvolvem em todo o horizonte. Transição gradual.

Horizonte Bt2: profundidade $70-90 \mathrm{~cm}$; apresenta uma estrutura poliédrica mais friável que o horizonte anterior e uma subestrutura microagregada. Os agregados apresentam uma coesão menor. A cerosidade diminui neste horizonte sendo comum e fraca. Cor: 2,5YR 3/4. Textura argilosa. Transição gradual.

Horizonte Bw: profundidade $90-200 \mathrm{~cm}+$; apresenta uma macroestrutura poliédrica fraca que se desfaz em uma microestrutura forte. Acima de $120 \mathrm{~cm}$ para cima a densidade do horizonte aumenta um pouco e desenvolve-se gradativamente nesta zona uma subestrutura poliédrica moderada. Cor: 2,5YR 3/4. Textura argilosa. Predomina a porosidade tubular entre os microagregados grandes. Presença de galerias biológicas de $2 \mathrm{~cm}$ de diâmetro preenchidas de microagregados maiores. Observa-se a presença de nódulos argilosos localizados que poderiam ser de origem biológica e alguns carvões distribuídos dentro deste horizonte. Observa-se a presença de algumas pontuações amarelas que são reliquias do material de origem (diabásio).

\section{Trincheira 2 (ombro)}

Esta trincheira foi dividida em sete horizontes: A, BA, Btl, Bt2, Bwl, Bw2 e BC; e classificada como uma Terra Roxa Estruturada Latossólica (Figura 7).

Horizonte A: profundidade $0-16 \mathrm{~cm}$; apresenta os primeiros $2 \mathrm{~cm}$ compactados e abaixo desta compactação desenvolve-se uma estrutura poliédrica média com uma subestrutura poliédrica fina. Cor: 2,5YR 3/4. Textura argilosa. Apresenta, associado aos agregados, partículas de quartzo limpo. As raízes desenvolvem-se nas paredes dos agregados, não conseguindo penetra-los. Transição gradual.

Horizonte BA: profundidade $16-34 \mathrm{~cm}$; horizonte muito semelhante ao correspondente na Trincheira 1. Apresenta estrutura poliédrica fina. Cor:2,5YR 3/6. 
Textura argilosa. Predomina a porosidade fissural entre os agregados e observa-se uma porosidade tubular menos desenvolvida que atravessa os agregados. As raizes penetram dentro dos agregados. Transição gradual.

Horizonte Btl: profundidade $34-77 \mathrm{~cm}$; apresenta estrutura poliédrica de tamanho centimétrico com cerosidade abundante e moderada recobrindo todos os agregados. Observa-se a presença de alguns revestimentos mais vermelhos que a matriz tendo uma provável origem iluvial; porém, como no perfil anterior, há uma dominância de cutãs. Cor: 2,5YR 3/6. Textura argilosa. Ocorre neste horizonte uma abundância de galerias de $5 \mathrm{~cm}$ de diâmetro; observa-se também a presença abundante de pedotúbulos preenchidos com um material mais denso, sendo que alguns apresentam orientações de argila e dos poros fissurais. Ocorre a presença de nódulos argilosos pequenos que vem dos horizontes inferiores e de fragmentos pequenos de diabásio. Transição gradual.

Horizonte Bt2: profundidade $77-103 \mathrm{~cm}$; apresenta estrutura poliédrica e subestrutura microagregada. A cerosidade diminui em relação ao horizonte anterior. Cor: 2,5YR 3/6. Textura argilosa. Porosidade tubular abundante que se distribui entre os microagregados. Observa-se a presença de pedotúbulos que contém abundantes nódulos argilosos pequenos. Observa-se também, a presença de fragmentos de diabásio. Um exame detalhado deste horizonte mostra um gradiente crescente em profundidade de nódulos de argila, diabásio e de seixos de quartzo (1-5mm). Transição gradual.

Horizonte Bw1: profundidade $103-130 \mathrm{~cm}$; apresenta estrutura microagregada que contém abundantes nódulos argilosos, de diabásio e seixos de quartzo de tamanho grande $(0,5 \mathrm{a} 2 \mathrm{~cm})$. Observa-se a presença de seixos diabásio com formato irregular. Cor: 2.5YR 3/6. Textura argilosa.

"Stone-line" ou linha de pedras: profundidade 130-142cm; formada por seixos de quartzo arredondado, nódulos de argila de até $5 \mathrm{~cm}$ de diâmetro e muitos seixos de diabásio. Observa-se a presença de nódulos ferruginosos amarelos e roxos com matriz de quartzo e a presença de outros materiais como siltitos. argilitos e arenitos com feições onduladas. Todo este material que compõe a "stone-line" se distribui dentro de uma matriz fina microagregada. 
Horizonte Bw2: profundidade $142-179 \mathrm{~cm}$; apresenta estrutura poliédrica fraca com uma subes rutura microagregada forte. Cor: 2,5YR 3/6. Textura argilosa. Presença de uma porosidade tubular que se distribui entre os microagregados. Ocorre a presença de nódulos argilosos pequenos e em menor quantidade que o horizonte de cima, nódulos ferruginosos pequenos e irregulares, e seixos pequenos de quartzo. Observou-se a presença de litorelíquias de diabásio amarelas e poucos, com tamanhos menores a $5 \mathrm{~mm}$, não microagregados. A diferença entre este horizonte e o Bw precedente, é a presença de litorelíquias de diabásio e a menor abundância e tamanho dos nódulos argilosos. Transição gradual.

Horizonte BC: profundidade $179-200 \mathrm{~cm}+$; presença abundante de relíquias de diabásio amarelas maiores ou iguais a $1 \mathrm{~cm}$ de diâmetro. rodeadas por uma matriz vermelha microagregada. Existe um gradiente na matriz amarela que passa para bege e logo vermelho. A matriz vermelha é microagregada podendo ser de origem geoquímica ou biológica. Observa-se uma porosidade tubular abundante que se distribui entre os microagregados. A microagregação se desenvolve ao redor dos poros tubulares. Presença abundante de raizes.

\section{Trincheira 3 (final do ombro)}

Esta trincheira foi dividida em seis horizontes: A, Bt1, "stone-line", Bt2. Bt3 e BC; e classificada como uma Terra Roxa Estruturada.

Horizonte A: profundidade $0-15 \mathrm{~cm}$; apresenta estrutura poliédrica de tamanho médio e friável com uma subestrutura poliédrica fina. Cor: 2,5YR 2,75/4. Textura argilosa. Apresenta uma porosidade fissural entre os agregados predominante e poros tubulares de $0,3 \mathrm{~cm}$ de diâmetro devido à atividade biológica. Observa-se a presença de seixos de quartzo e nódulos de ferro de $0,5 \mathrm{~cm}$ de diâmetro. Na superfície observa-se uma compactação de $2-3 \mathrm{~cm}$ de profundidade e que se desenvolvia mais nos locais de passagem dos animais e desaparecia embaixo dos tufos da pastagem. Presença de raízes que penetram nos agregados. A transição é gradual e ocorre numa espessura de $5 \mathrm{~cm}$ apresentando o desenvolvimento de uma subestrutura poliédrica pequena. 
Horizonte Btl: profundidade $15-35 \mathrm{~cm}$; apresenta estrutura poliédrica de tamanho médio e subestrutura prismática. Na parte superior do horizonte, de 15 a $25 \mathrm{~cm}$, observa-se uma subestrutura poliédrica fina. Não se observou subestrutura microagregada. A cerosidade é abundante e moderada. Cor: 2,5YR 2,75/4. Textura argilosa. Apresenta uma porosidade tubular grosseira de origem biológica e fissural dominante entre os agregados. Observa-se a presença de restos de diabásio e seixos de quartzo $(<1 \mathrm{~mm}$ de diâmetro). As raízes penetram em todo o horizonte.

"Stoneline" ou linha de pedra: profundidade $35-50 \mathrm{~cm}$; composta por seixos de quartzito de diferentes tamanhos $(0,5$ até maiores que $5 \mathrm{~cm})$, seixos de diabásio de 10 a $20 \mathrm{~cm}$ de diâmetro e outros materiais associados não identificados. Estes materiais estão distribuídos dentro de uma matriz fina argilosa. Observa-se a presença de dois tipos de nódulos de argila: uns maiores com quartzo dentro da sua matriz e outros menores. sem quartzo, provavelmente de origem biológica. Os nódulos maiores estariam associados à "stoneline". Observa-se que a alteração do diabásio se dá de forma concêntrica de fora para dentro. As raízes se desenvolvem e chegam até a borda da rocha em alteração. A "stoneline" tem um formato plano e homogêneo.

Horizonte Bt2: profundidade $50-100 \mathrm{~cm}$; apresenta estrutura poliédrica de tamanho médio com subestrutura poliédrica fina $(5 \mathrm{~mm})$ bem desenvolvida diferente dos horizontes superfíciais. Não há indícios de subestrutura microagregada. A cerosidade é abundante e moderada. Cor: 2,5YR 3/6. Textura argilosa. Apresenta uma porosidade fissural dominante, presença de muitas galerias biológicas e de pedotúbulos com preenchimentos argilosos muito densos. Observa-se a presença de nódulos litorreliquiais pequenos, menores que $1 \mathrm{~cm}$ de diâmetro, de seixos de quartzo menores que $1 \mathrm{~cm}$ e de fragmentos pequenos de diabásio. Transição gradual principalmente de cor.

Horizonte Bt3: profundidade $100-150 \mathrm{~cm}$; estrutura poliédrica média mais friável que o horizonte anterior com uma subestrutura poliédrica menos desenvolvida em relação ao horizonte anterior e de tamanho maior $(1 \mathrm{~cm})$. Cerosidade abundante e moderada. Cor: 2,5YR 3,5/6. Textura argilosa. Presença de uma porosidade tubular fina muito abundante e fissural associada. Observaram-se galerias grandes com diâmetros entre 2 e $3 \mathrm{~cm}$. Presença 
de uma areia preta (magnetita) e relíquias de diabásio de 1 a 1,5cm de diâmetro. Transição gradual.

Horizonte BC: Horizonte classificado como uma isoalterita. Profundidade 150$170+\mathrm{cm}$; apresenta uma matriz amarela com uma estrutura pedomassiva e uma estrutura poliédrica não completa. Apresenta uma cerosidade abundante de cor vermelha que se distribui sobre os agregados amarelos e sobre a porosidade fissural. Cor 5YR 4/6. Textura média quase argilosa. Observa-se uma porosidade tubular e uma porosidade de dissolução entre as partículas. Presença de organizações tubulares vermelhas que apresentam estrutura microagregada. Observa-se a presença de muitas reliquias de diabásio que aumentam em profundidade. Dentro das reliquias de diabásio há cores bege claros (5YR 6/6 e 5YR 8/4), vermelhas (5YR 4/8 e minerais pretos (2,5YR 2,5/0). Em profundidade observa-se uma estrutura de isoalterita de formato concêntrico e a presença de túbulos que a penetra contendo uma matriz muito densa e microagregada.

As descrições morfológicas das trincheiras mostraram uma interdependência entre os horizontes $\mathrm{Bt}$ e $\mathrm{Bw}$, havendo evidências que a passagem lateral e vertical entre estes horizontes ocorre por um processo de adensamento. Esta hipótese será verificada posteriormente através dos estudos micromorfológicos, de análise de imagens e da dinâmica da água do solo.

\subsubsection{Características analíticas dos horizontes}

A análise das características granulométricas e químicas dos solos estudados mostram grande homogeneidade (Tabelas 3 e 4).

Observa-se que apesar dos horizontes apresentarem tipos de estrutura diferentes, como será visto na próxima seção, elas apresentam uma textura homogênea em quase todo o perfil, sendo esta considerada argilosa a muito argilosa.

A densidade do solo apresenta valores entre 1.45 e $1,64 \mathrm{~g} / \mathrm{cm}^{3}$ para os horizontes Bt tendo valores semelhantes nas trincheiras 1 e 2 e sendo um pouco mais densa na trincheira 3. Para o horizonte Bw observam-se valores entre 1,2 e $1,39 \mathrm{~g} / \mathrm{cm}^{3}$. Observam-se 
dois sentidos de adensamento nesta sequência, uma vertical entre o horizonte $\mathrm{Bw}$ e $\mathrm{Bt}$, e outra lateral, entre os horizontes Bt das duas primeiras trincheiras e a última e dentro do Bw da trincheira 1 para a 2 (Tabela 3 ).

No que concerne aos dados químicos, observa-se que o $\mathrm{pH}$ destes solos encontrase entre 5,0 e 6,5, sendo a distribuição entre os horizontes bastante homogênea. Os valores superficiais altos de fósforo e soma de bases deve-se à influência da adubação nestes horizontes.

Os valores de $T$ do solo decrescem a medida que descemos nos perfis 1 e 2 , observando-se os valores mais baixos entre 52 e $71 \mathrm{mmol}_{\mathrm{c}} \mathrm{kg}^{-1}$ nos horizontes $\mathrm{Bw}$. Nos horizontes Bt destes perfis ( 1 e 2) os valores de T são intermediários podendo ser mais elevados devido à maior influência da matéria orgânica nestes horizontes. No perfil 3 encontram-se os valores mais altos de $T$ do transeto isto pode ser devido à presença de minerais de argila 2:1 devido à proximidade da rocha.

Tabela 3. Granulometria dos solos estudados.

\begin{tabular}{|c|c|c|c|c|c|c|c|c|}
\hline Ident & $\begin{array}{c}\text { AMG } \\
\%\end{array}$ & $\begin{array}{c}\mathrm{AG} \\
\%\end{array}$ & $\begin{array}{l}\mathrm{AM} \\
\%\end{array}$ & $\begin{array}{l}\mathrm{AF} \\
\%\end{array}$ & $\begin{array}{c}\text { AMF } \\
\%\end{array}$ & $\begin{array}{l}\text { Silte } \\
\%\end{array}$ & $\begin{array}{c}\text { Argila } \\
\%\end{array}$ & $\begin{array}{c}\text { Dens.solo } \\
\mathrm{r} / \mathrm{cm}^{3}\end{array}$ \\
\hline TIA $0-10$ & 0,54 & 2,62 & 5,94 & 16,56 & 1.5 & 18,2 & 54.6 & 1.44 \\
\hline TIBA $10-30$ & 0,44 & 1,08 & 4,4 & 15,44 & 4,4 & 14.4 & 59.8 & 1,53 \\
\hline$T I B+130-70$ & 0,26 & 1,02 & 3,54 & 12,74 & $0 . \bullet$ & 10.4 & 74.9 & 1.47 \\
\hline T1Bt2 $70-90$ & 0,26 & 1,06 & 3,8 & 13.72 & 1,8 & 8,1 & 71.2 & 1.22 \\
\hline TIBw 90+ & 0.26 & 1,02 & 3.44 & 12.6 & 5.6 & 12.5 & 64.6 & 1.20 \\
\hline T2A $0-16$ & 0,46 & 2,78 & 6,24 & 14.56 & 3.2 & 18,2 & 54,5 & 1,47 \\
\hline T2BA $16-34$ & 0,2 & 1,08 & 3,36 & 12.5 & 2,8 & 14.0 & 66.1 & 1.45 \\
\hline T2Bt1 34-77 & 0,1 & 0.52 & 2,3 & 9,84 & 5,2 & 10,0 & 72.1 & 1.47 \\
\hline $\mathrm{T} 2 \mathrm{Bt} 277-10.3$ & 0,1 & 0,54 & 3,18 & 13,04 & 2,7 & 14,1 & 66.3 & 1,45 \\
\hline T2Bw1 103-120 & 0.32 & 1.04 & 2,82 & 12,64 & 7,3 & 13.0 & 62.9 & 1.39 \\
\hline T2Bw2 142-179 & 0.4 & 0,82 & 2,68 & 11,08 & 9,2 & 19,5 & 56.3 & 1.38 \\
\hline T2BC $179-200$ & 0 & 0,86 & 3,82 & 13,8 & 0.2 & 28.5 & 53,0 & - \\
\hline T3A0-15 & $\overline{0,3}$ & 2,28 & 9,16 & 12.62 & 4.6 & 18.3 & 52.7 & 1.47 \\
\hline $\mathrm{T} 3 \mathrm{~B}+115-35$ & 0,24 & 1,04 & 4,9 & 15,16 & 3,4 & 18.3 & 57.0 & 1,64 \\
\hline T3Bt2 50-100 & 0,24 & 1,06 & 4,1 & 10,7 & 1,1 & 16.2 & 66,7 & 1.63 \\
\hline $\mathrm{T} 3 \mathrm{~B}+31 \bullet 0-150$ & 0,12 & 0.76 & 3,98 & 11,44 & 2.9 & 24.2 & 56.6 & 1.59 \\
\hline $\mathrm{T} 3 \mathrm{BC} 150 \mathrm{~cm}$ & & & & & & & & 1.50 \\
\hline
\end{tabular}


Tabela 4: Análises físico-químicas dos solos estudados.

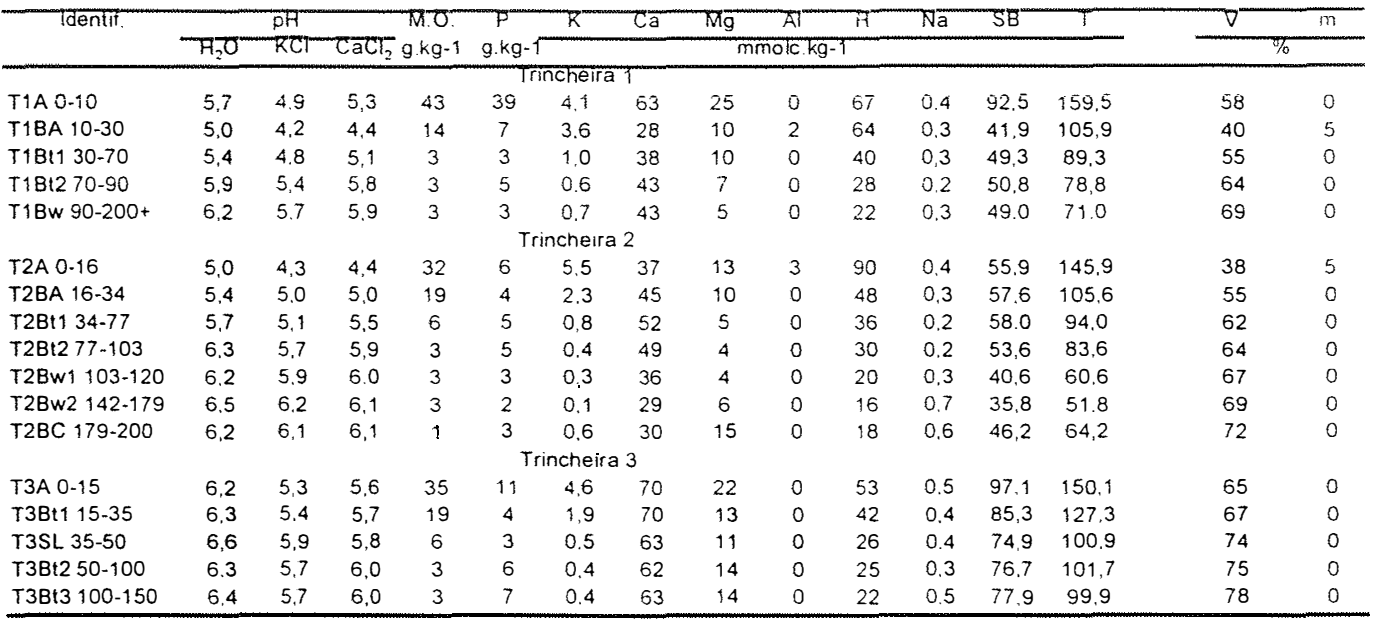

M.O.= matéria orgànica; $\mathrm{S} . \mathrm{B}=$ = soma de bases: $\mathrm{T}=$ capacidade de troca de cations; $\mathrm{V}=$ saturação por bases; $\mathrm{m}=$ saturaçăo por aluminio

\subsubsection{Características micromorfológicas dos horizontes da transição Bt-Bw-alterita}

A descrição sistemática da micromorfologia dos perfis estudados está apresentada na forma de quadro-resumos no Apêndice 1. A seguir apresenta-se as principais características micromorfológicas dos horizontes da transição $\mathrm{Bt}-\mathrm{Bw}$ dos três perfis estudados. A descrição foi realizada seguindo a metodologia proposta por Bullock et al. (1985).

\section{- Perfil 1:}

O perfil 1 apresenta as seguintes características dominantes para a transição Bt Bw. Foram descritos os seguintes horizontes: $\mathrm{Bt} 1, \mathrm{Bt} 2$, transição $\mathrm{Bt} 2 / \mathrm{Bw}$ e $\mathrm{Bw}$.

O horizonte Bt1 apresenta-se muito heterogênea identificando-se três zonas diferenciadas pela sua porosidade e estrutura. Observou-se a passagem de uma zona densa de trama porfirica que apresenta agregados poliédricos subangulares, um plasma isótico e uma porosidade fissural interagregados e mamelonar intragregados dominante, para uma zona microagregada de trama enáulica. com plasma isótico e uma porosidade dominante de empilhamento (Figura 8). A zona intermediária de trama porfírica aberta, dominante, apresenta uma microestrutura mista com agregados poliédricos e aglomerados de 
microagregados, a porosidade dominante é policôncava (interagregados) e mamelonar (intragregados). Este horizonte apresenta ferri-argilãs de iluviação (20\%) localizados principalmente na porosidade policôncava e de empilhamento (Figura 9a e b), alguns deles foram modificados pelos movimentos de massa do solo e apresentam orientação manchada. Observam-se cutãs de difusão de ferro nas bordas de alguns agregados.

As observações realizadas no horizonte Bt2 mostraram duas zonas bem distintas, uma zona densa porfírica e uma zona microagregada enáulica dominante. A zona densa apresenta agregados poliédricos subangulares com uma porosidade mamelonar dominante e fissuras entre os agregados (Figura 8). A zona microagregada apresenta microagregados de diversas formas e aglomerados de microagregados com uma porosidade de empilhamento e microfissuras entre estes. O plasma é isótico apresentando algumas zonas isoladas vossépicas. Aumenta a quantidade de ferri-argilãs em relação ao horizonte Bt1. Observa-se também a presença de alguns ferrãs.

A transição entre os horizontes $\mathrm{Bt} 2$ e $\mathrm{Bw}$ apresenta as mesmas características gerais que o horizonte Bt2. Nesta ocorre um maior grau de desenvolvimento da estrutura microagregada. Não se observa o desenvolvimento de cutãs de iluviação e ferrãs e o plasma é isótico na sua totalidade.

O horizonte $\mathrm{Bw}$ apresenta-se bastante homogêneo apresentando uma única zona de trama enáulica com pequenas zonas muito localizadas mais densas (Figura 10a e b). A microestrutura é microagregada observando-se também aglomerados de microagregados e poucos agregados poliédricos subangulares. O plasma é isótico e apresenta uma porosidade de empilhamento dominante. Secundáriamente, observa-se a presença de canais e cavidades biológicos e uma porosidade mamelonar dentro dos aglomerados de microagregados.

Neste perfil observa-se uma transformação vertical e gradual da estrutura entre os horizontes $\mathrm{Bw}$ e $\mathrm{Bt}$, passando de uma estrutura microagregada no Bw para uma poliédrica subangular no Bt1. As observações sugerem a ocorrência de um adensamento dos microagregados nos horizontes Bt (Figura 8c), evidenciada pela presença de poros mamelonares dentro dos agregados dos horizontes adensados. A presença de fissuras 
evidenciariam processo de contração e expansão do material processo que levaria à formação dos agregados poliédricos. Nas zonas mais densas e nos aglomerados de microagregados observaram-se microfissuras, que formadas pelos mesmos processos de expansão e contração, estariam formando microagregados poliédricos por este processo.

Os ferri-argilãs estão localizados principalmente na porosidade mamelonar intragregados e na porosidade fissural provocando, também, o adensamento material (Figura 9a e b). Estes estão localizados nos horizontes mais superficiais onde a drenagem é menor desaparecendo nos horizontes mais porosos. A presença de cutãs de difusão, ferrãs e em alguns locais a presença de um plasma vossépico, evidenciaria processos de segregação e migração de ferro provavelmente devido a períodos curtos de hidromorfia.

A atividade biológica é grande em todo o perfil, evidenciada pela presença generalizada de pedotúbulos. Estes apresentam as paredes adensadas o que poderia estar ajudando nos processos de coalescência de microagregados.

\section{- $\quad$ Perfil 2}

Foram escolhidos neste perfil os horizontes $\mathrm{Bt} 1, \mathrm{Bt} 2, \mathrm{Bw} 1, \mathrm{Bw} 2$ e Bw2/BC para realizar as descrições micromorfológicas visando a transiçãoBt-Bw.

O horizonte Bt1 caracteriza-se por apresentar duas zonas que apresentam uma trama porfírica que se diferenciam no desenvolvimento da porosidade mamelonar e policôncava. A zona mais densa apresenta agregados poliédricos subangulares mas dentro dos poros cavitários observa-se a presença de microagregados. A porosidade dominante nesta zona é a fissural enquanto que na zona menos densa são os poros policôncavos e mamelonares (Figura 8a). O plasma é isótico. Observa-se a presença de ferri-argilãs (20\%) distribuídos dentro da porosidade policôncava, mamelonar e fissural (Figura 9a e b). A presença de cutãs de difusão, neo-cutãs e pápulas evidenciam uma possível movimentação de ferro e da massa do solo.

Contrastando com o horizonte Bt1, o horizonte Bt2 apresenta-se menos densa. A zona dominante apresenta uma trama pórfiro-enáulica formada por uma microestrutura composta por agregados poliédricos subangulares e aglomerados de microagregados. A porosidade dominante desta zona é mamelonar apresentando alguns canais, cavidades e 
fissuras (Figura 8b). Observa-se a presença de ferri-argilãs de iluviação (20\%) e cutãs de difusão.

Duas zonas foram também observadas no horizonte Bwl. A zona dominante apresenta uma trama pórfiro-enáulica com algumas áreas enáulicas. A microestrutura é formada principalmente por aglomerados de microagregados e microagregados de formas variadas. A porosidade apresenta poros policôncavos abertos como dominantes observando-se também canais, cavidades e fissuras. Em contraste, a outra zona é mais densa com trama porfírica sendo formada por agregados poliédrico subangulares onde dominam poros mamelonares e fissurais (Figura 9c). Não se observou a presença de ferriargilãs e cutãs de difusão.

Em contraste ao horizonte Bwl, o horizonte Bw2 apresenta uma trama enáulica como dominante. Observam-se também zonas menores com tramas pórfiro-enáulica e porfírica, sendo a transição entre elas gradual (Figura 9d). A microestrutura dominante é a microagregada observando-se também a presença de aglomerados de microagregados e isoladamente agregados poliédricos subangulares. A porosidade de empilhamento é dominante observando-se poros mamelonares desenvolvidos dentro dos agregados poliédricos e aglomerados de microagregados. Canais, cavidades e fissuras também estão presentes.

A transição para o horizonte $\mathrm{BC}$ mostra-se muito heterogênea, aparecendo zonas relictuais de alteração de diabásio num fundo matricial formado por materiais em diferentes estágios de pedogeneização. Desta forma as zonas relictuais de diabásio brunoamareladas estão formados por agregados poliédrico subangulares e microagregados que apresentam uma porosidade mamelonar, fissural e alguns canais e cavidades. O material mais pedogeneizado, de cor vermelha escura, apresenta várias densidades, podendo ser bem densa e porfírica apresentando uma estrutura poliédrica subangular até microagregada e enáulica com dominância de poros de empilhamento (Figura 10c). Entre estas duas zonas encontra-se uma zona intermediária que apresenta uma trama pórfiro-enáulica, aglomerados de microagregados e poros mamelonares como características dominantes. 
A semelhança do perfil anterior, este perfil mostra uma transição gradual e vertical entre os horizontes Bt adensados e horizontes Bw microagregados (Figura 9d). As evidências micromorfológicas mostram que o processo desta transformação estrutural seria o mesmo ao do perfil 1. A presença de pápulas e cutãs de difusão sugeririam a movimentação da massa do solo por forças de contração e expansão e movimentação de ferro, respectivamente.

A presença generalizada de pedotúbulos, na forma de ortotúbulos, evidenciam a intensidade da atividade biológica da fauna neste solo. O adensamento das paredes destes ortotúbulos evidencia, como no perfil anterior, a ação mecânica de coalescência de microagregados exercida pela mesofauna.

\section{- Perfil 3}

No último perfil descrito observa-se o desaparecimento do horizonte $\mathrm{Bw}$ e o material de origem aparece mais próximo da superfície. A seqüência de horizontes estudadas é Bt1, Bt2, Bt3, alterita e coração da alteração (a $30 \mathrm{~cm}$ da rocha mãe).

O horizonte Btl apresenta duas zonas porfiricas que foram diferenciadas principalmente pela cor e pela porosidade. A zona dominante apresenta uma cor vermelha escura, uma microestrutura caracterizada por agregados poliédricos subangulares com pedalidade moderada a fraca e uma porosidade dominante mamelonar. A outra zona apresenta cores brunas-avemelhadas, agregados poliédicos subangulares com uma pedalidade moderada. A porosidade desta zona e predominantemente fissural apresentando, também, poros mamelonares e cavidades biológicas. O plasma na zona vermelho escuro apresenta-se isótica, enquanto que na bruno-avermelhada ela é isótica com algumas áreas vossépicas e argilassépicas Observou-se a presença de ferri-argilãs $(15 \%)$ preenchendo principalmente os poros mamelonares e fissurais.

O horizonte Bt2 apresenta-se bastante homogêneo, de cor vermelha escura. com trama porfírica e bastante denso. Apresenta agregados poliédricos subangulares e uma pedalidade moderada. O plasma é isótico mas localmente apresenta-se vossépica e argilassépica. Os poros mamelonares predominam observando-se também canais, 
cavidades e algumas fissuras. Observou-se a abundante presença de ferri-argilãs (30\%) de cores vermelhas brilhantes localizados nos poros mamelonares.

Duas zonas foram distinguidas no horizontes $\mathrm{Bt} 3$, uma com uma trama porfïrica e outra pórfiro-enáulica. A zona porfírica é dominada por agregados poliédricos subangulares contrastando com a outra zona que apresenta uma macroestrutura dominada por aglomerados de microagregados e agreagados poliédricos subangulares. A porosidade diferencia-se principalmente no desenvolvimento dos poros mamelonares, sendo maior na zona pórfiro-enáulica, observando-se também nesta poros policôncavos. $\mathrm{O}$ plasma nas duas zonas apresenta dominios vossépicos, argilassépicos e insépicos. Como observado no horizonte anterior ocorre uma presença abundante de ferri-argilãs de iluviação preenchendo os poros mamelonares, fissurais e policôncavos.

A lâmina da alterita mostra duas zonas bem definidas com uma transição gradual entre elas. A primeira delas corresponde a uma zona de alteração formada por um alteroplasma com birrefringência argilassépica de cor bruna e bruna amarelada composta principalmente por plagioclásios alterados e caulinita. Apresenta uma trama pórfiroenáulica e a porosidade é dominada por fissuras e poros mamelonares. A segunda corresponde a um pedoplasma argilassépico e isótico de cor avermelhada e brunoavermelhada que apresenta uma trama porfírica e pórfiro-enáulica. A microestrutura é formada por agregados poliédricos subangulares e aglomerados de microagregados. A porosidade é dominada por poros mamelonares e policôncavos e alguns canais e cavidades biológicas e fissuras.

A última lâmina descrita nesta trincheira corresponde a um material coletado na interface entre a rocha pura e a alterita. Três zonas foram descritas nesta lâmina, a primeira corresponde a uma zona dominada por alteroplasma (40\%) onde pode-se observar ainda a estrutura conservada da rocha, a segunda uma zona transicional onde ocorre uma diminuição do tamanho do esqueleto e o plasma fica mais vermelho e a terceira uma zona dominada por pedoplasma apresentando uma estrutura pedológica e uma diminuição na quantidade de minerais primários. Tanto na zona transicional como na zona pedogeneizada observa-se um plasma argilassépico e isótico onde ocorre uma maior concentração de 
ferro, a microestrutura é caracterizada por ser incipiente e estar formada por agregados poliédricos subangulares e aglomerados de microagregados (Figura 10d). A porosidade em todo o horizonte apresenta poros mamelonares e policôncavos como dominantes, observando-se também a presença de canais, cavidades e fissuras (Figura 10d). Da mesma forma que a porosidade a trama também é constante em todo o horizonte, sendo porfírica.

A partir do horizonte $\mathrm{Bt} 3$, o esqueleto não é exclusivamente formado por quartzo como foi observado no resto da sequência. Começam a aparecer plagioclásios alterados e minerais ferro-magnesianos como componentes do esqueleto. Ao passar para a alteração estes ganham em importância ocupando uma posição de dominância principalmente nos alteroplasmas que caracterizam as zonas com estrutura conservada da rocha e minerais.

Em todos os horizontes foi constatada uma forte atividade biológica. Esta foi evidenciada pela presença de ortotúbulos bem desenvolvidos que apresentavam as suas paredes adensadas e alguns estavam preenchidos com microagregados.

$\mathrm{Na}$ alteração linhas de penetração de ferro foram observadas no material alterado de plagioclásios e caulinita. Este ferro aproveita as pequenas fissuras do material para penetrar e logo se concentrar em núcleos arredondados dentro de uma matriz caulinítica. Estes núcleos de associação do ferro com a caulinita poderiam ser interpretados como precursores dos microagregados de origem geoquímica. Uma posterior dissolução dos minerais não impregnados pelo ferro provocaria a individualização destes microagregados.

Apesar de observar-se na alteração deste perfil a formação de microagregados, estes não chegam a desenvolver-se completamente para formar um horizonte microagregado (Figura 10d). Devido à posição que ocupa o perfil na paisagem. isto poderia ser explicado pela pouca permanência da água no local devido à existência de um fluxo lateral da água desfavorecendo, desta forma, os processos que levam à continuidade da individualização dos microagregados. A abundante presença de cutãs de iluviação preenchendo principalmente a porosidade mamelonar e policôncava originada pelo incipiente processo de individualização de microagregados, seria um processo secundário que originaria os horizontes densos sobrejacentes. 

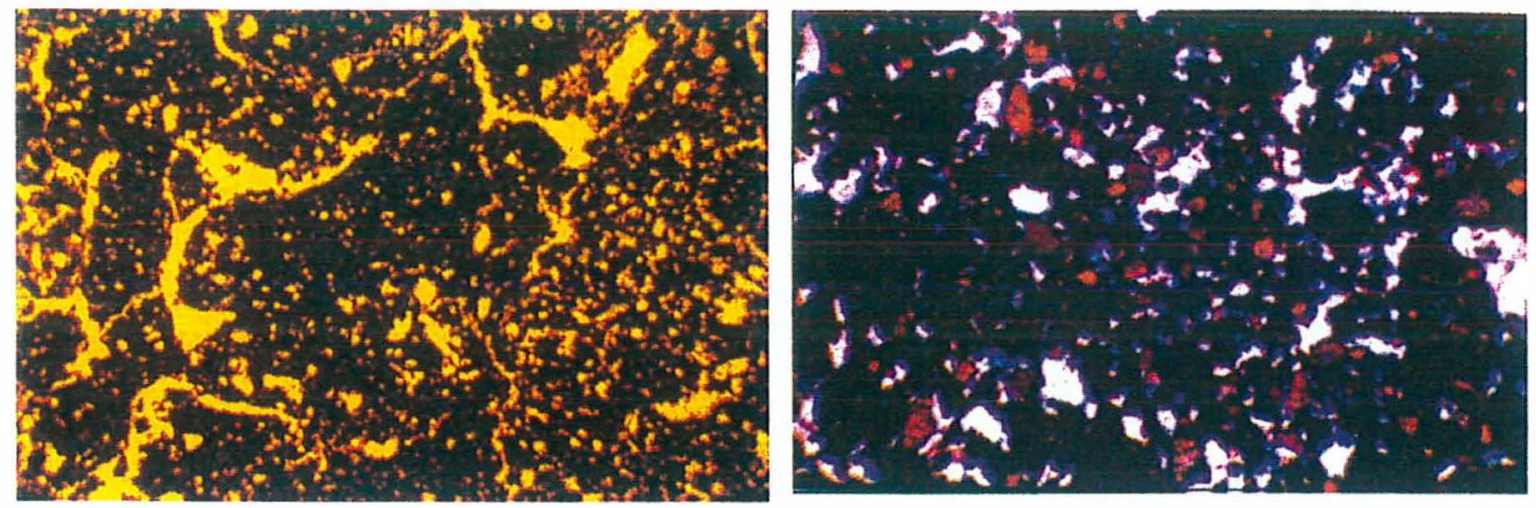

A) T2 Bt1. Trama porfírica fissurada B) T2 Bt2. Detalhe da porosidade mamelonar formando agregados poliédricos. Observam- intragregados (Luz ultra-violeta) se poros mamelonares dentro dos agregados (Luz natural)

\section{$2000 \mu \mathrm{m}$}

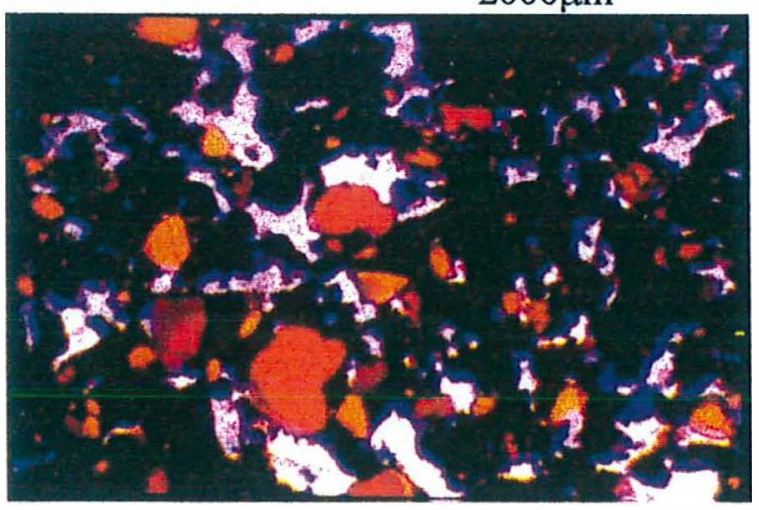

$500 \mu \mathrm{m}$

C)T1 Bt2. Detalhe da porosidade mamelonar intragregados (Luz ultra-violeta)

\section{$300 \mu \mathrm{m}$}

Figura 8: Fotomicrografias dos horizontes Bt adensados com detalhamento da porosidade marnelonar. 


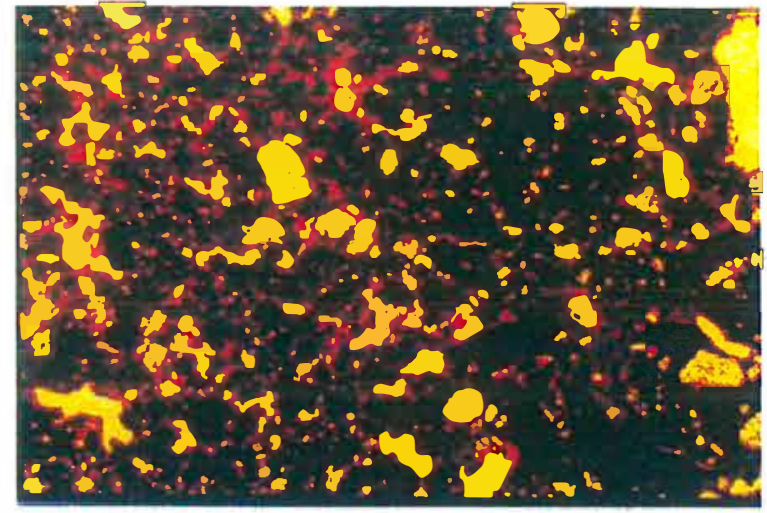

A) T2 Bt2. Trama porfirica. Ferri-argilãs preenchendo a porosidade mamelonar e fissural (Luz natural)

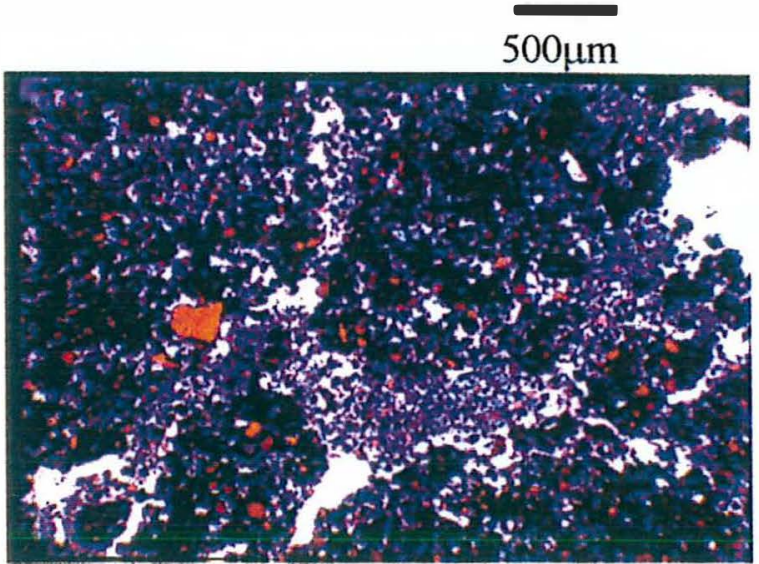

C) T1 Bt2/Bw. Trama pórfiro-enáulica. Transição mostrando a heterogeneidade do material com zonas densas microagregadas.(Luz ultra-violeta)

$$
2000 \mu \mathrm{m}
$$

Figura 9: Fotomicrografias do horizonte $\mathrm{Bt}$ sendo adensado pelo preenchimento da porosidade por ferri-argilãs de iluviação e da transição entre os horizontes adensados e microagregados.

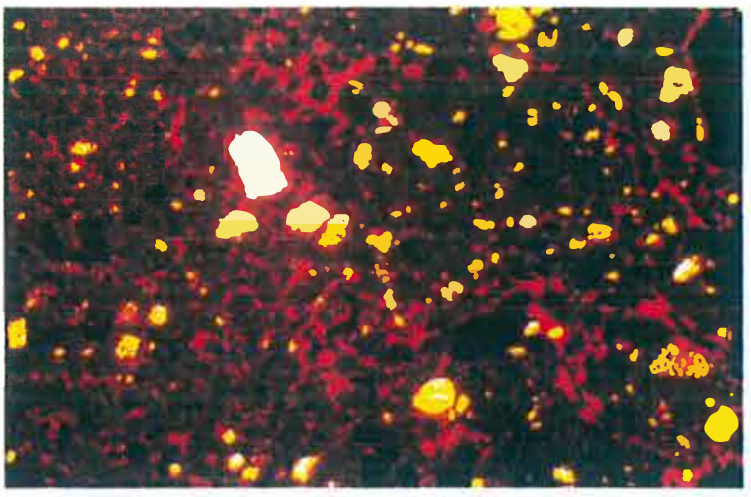

B) T2 Bt2. Idem à anterior com nícois cruzados

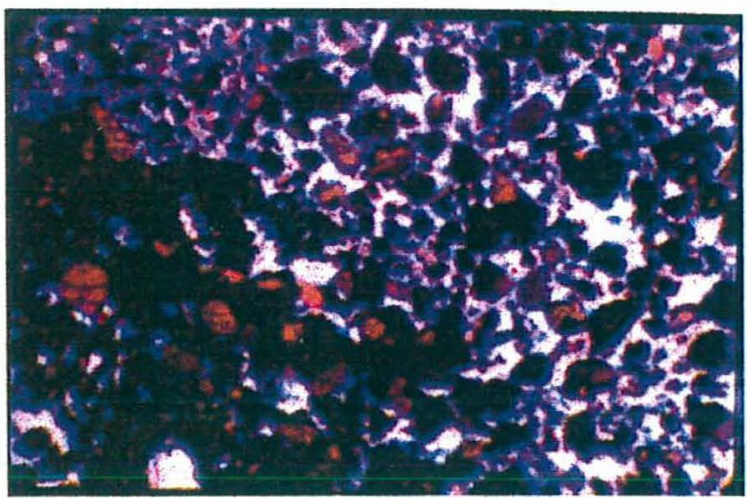

D) T1 Bt2/Bw. Trama pórfiro-enáulica. Detalhe da transição de uma zona densa para e uma microagregada (Luz ultra-violeta).

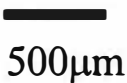

$500 \mu \mathrm{m}$ 


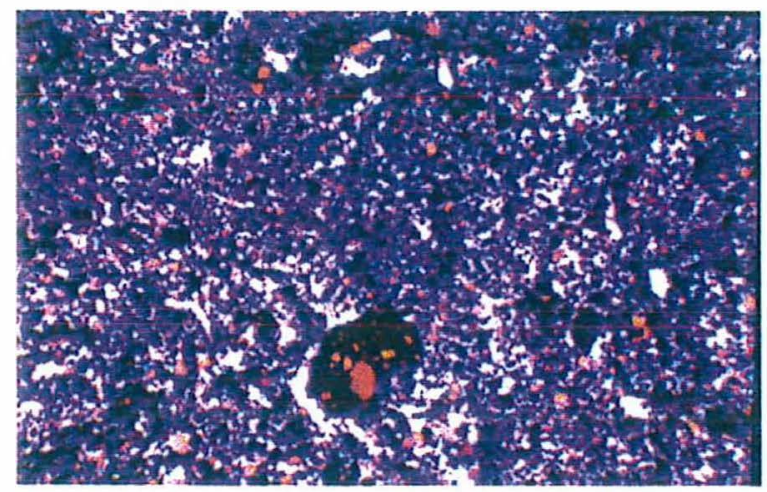

A) $\mathrm{Tl} \mathrm{Bw}$ Trama enáulica do horizonte microagregado. Observa-se a grande heterogeneidade das formas e tamanhos de microagregados. (Luz ultra-violeta)

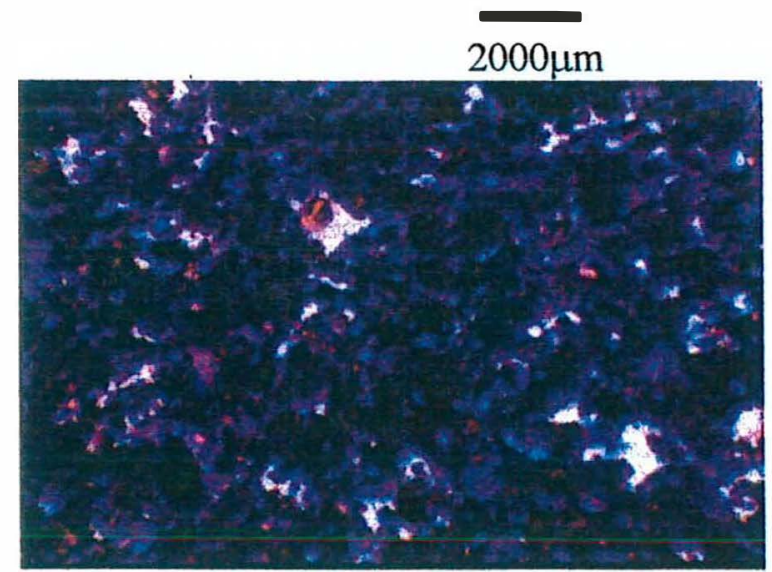

C) T2 BC. Trama porfirica. Observa-se a porosidade mamelonar formada na alterita e os núcleos de concentração de ferro prováveis precursores dos microagregados. (Luz ultravioleta)

\section{$500 \mu \mathrm{m}$}

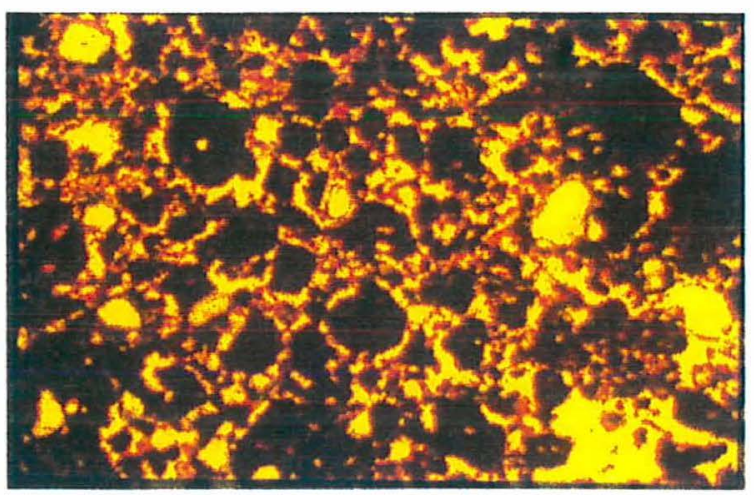

B) Tl Bw. Trama enáulica. Detalhe dos microagregados e sua heterogeneidade de formas e tamanhos. (Luz natural)
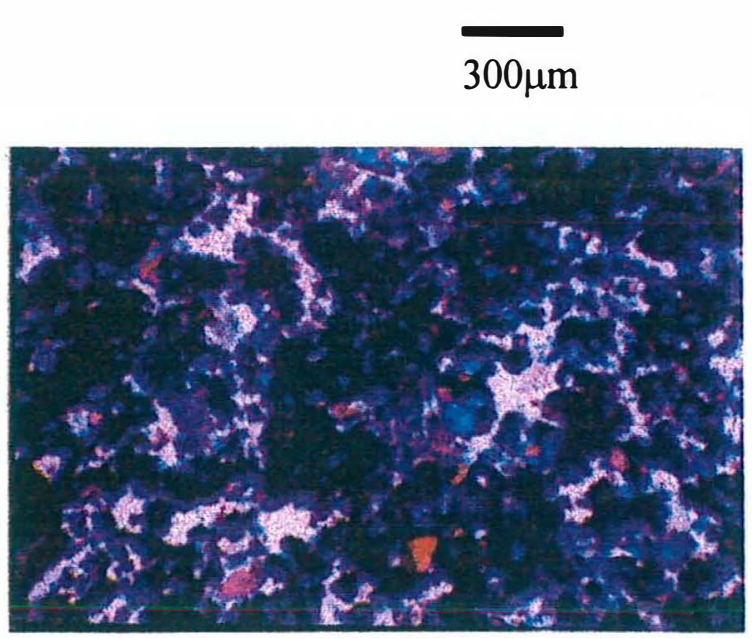

D) T3 alterita. Porosidade mamelonar e policôncava e formação de microagregados na alterita. (Luz ultra-violeta)

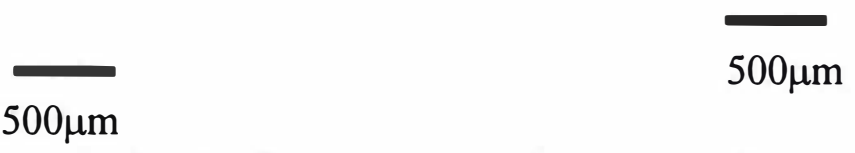

Figura 10: Fotomicrografias dos horizontes Bw microagregados e da alterita. 


\subsubsection{Características submicroscópicas e microanalíticas dos horizontes da transição}

\section{Bt-Bw-alterita}

Baseado nas descrições micromorfológicas várias questões de dificil solução nas resoluções do microscópio ótico precisaram da utilização do microscópio eletrônico de varredura para a sua explicação. Também foi utilizado o microanalizador para determinar as composições elementares dos materiais e como estes evoluem.

Assim várias questões como a formação da porosidade policôncava e mamelonar, a formação de microagregados e dos agregados poliédricos subangulares, a formação dos ferriargilãs de iluviação, e a formação do fundo matricial isótico e rico em ferro. serão discutidas utilizando estas técnicas.

As imagens das Figuras 11 e 12 tomadas a partir do microscópio eletrônico de varredura ilustram a porosidade mamelonar e policôncava descrita anteriormente na análise micromorfológica. Esta técnica permitiu identificar duas origens para este tipo de porosidade. A primeira refere-se à porosidade mamelonar e policôncava desenvolvida nos horizontes $\mathrm{Bt}$ e $\mathrm{Bw}$ dos dois primeiros perfis. Nestas onde fica caracterizada. tanto lateralmente como verticalmente, a transição Bt-Bw, as imagens confirmam a origem desta porosidade devido à coalescência de microagregados. Isto fica muito bem evidenciado na seqüência de imagens apresentadas na Figura 11, onde pode-se observar claramente a disposição adensada dos microagregados com a conseqüente formação da porosidade mamelonar e policôncava.

A segunda refere-se à porosidade mamelonar e policôncava formada no perfil 3 nos horizontes Bt e de alteração (Figura 12). A origem desta porosidade neste perfil seria fỉsico-química resultado da dissolução ou redistribuição de minerais. Os processos de pedogênese provocariam uma re-organização do fundo matricial caulinítico, principalmente os processos de formação de microagregados como será explicado mais a frente, o que levaria à formação deste tipo de porosidade. 


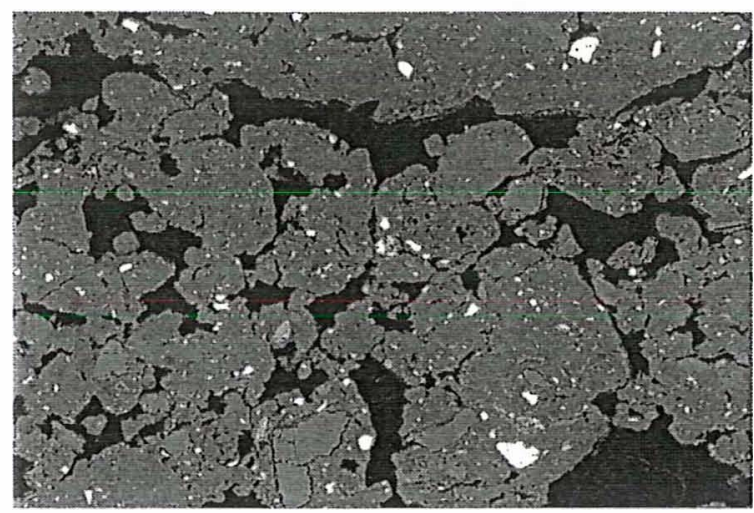

a) $\mathrm{T} 2 \mathrm{Bw} 2(166 \mathrm{x})$

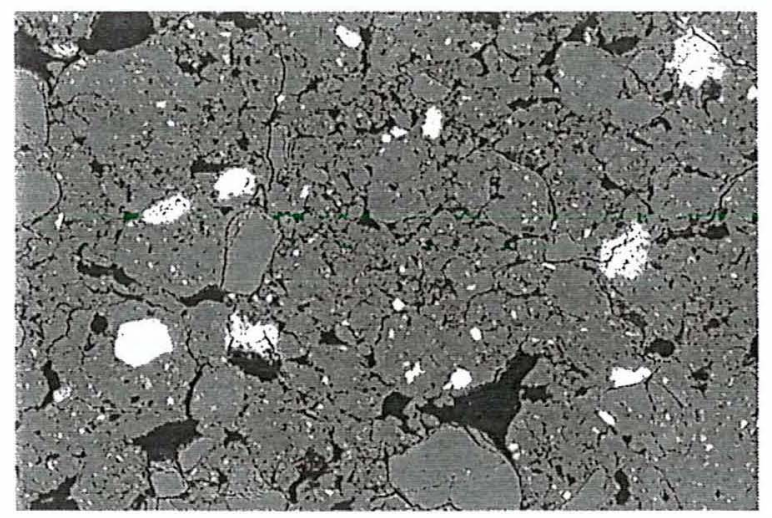

c) Tl Bw (166x)

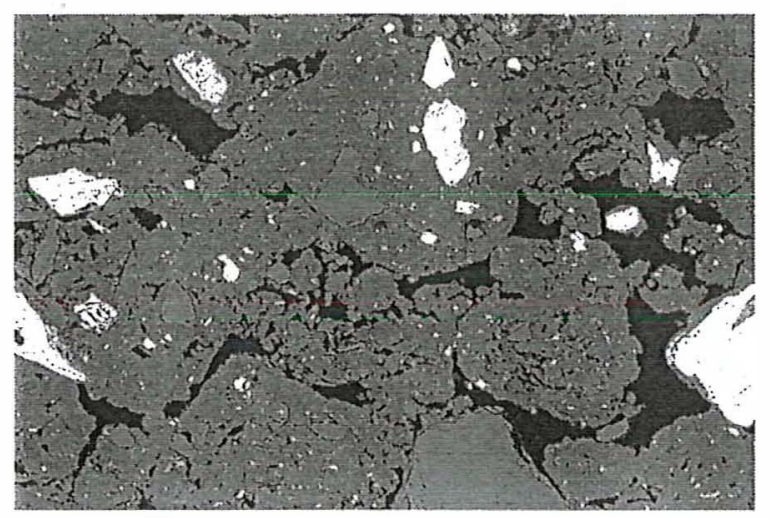

b) $\mathrm{Tl} \mathrm{Bt} 2 / \mathrm{Bw}(166 \mathrm{x})$

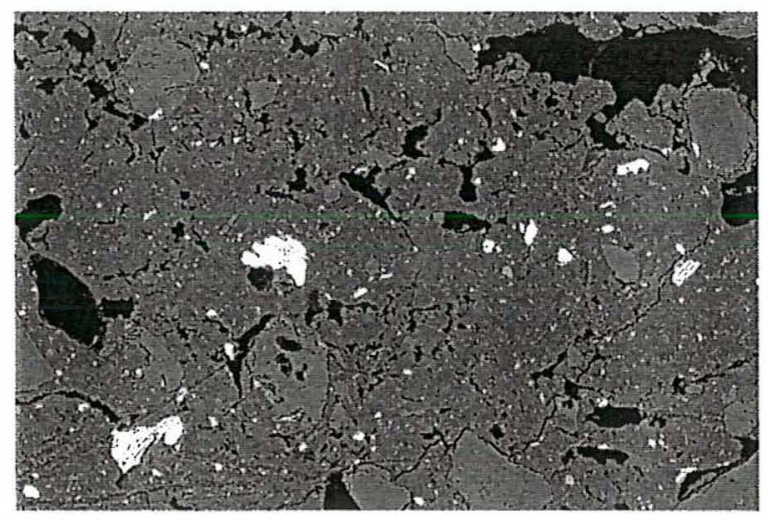

d) TlBtl (166x)

\section{$100 \mu \mathrm{m}$}

Figura 11: Porosidade mamelonar e policôncava formada pela coalescência de microagregados

A seqüência de imagens da Figura 13 ilustra os processos de organização e adensamento do fundo matricial isótico e rico em ferro. Foi caracterizado sob microscópio ótico a presença de um fundo matricial nos horizontes pedológicos denso, isótico e vermelho escuro (Figura 13f). O estudo deste material e da alteração no microscópio eletrônico de varredura permitiu explicar a sua origem. 


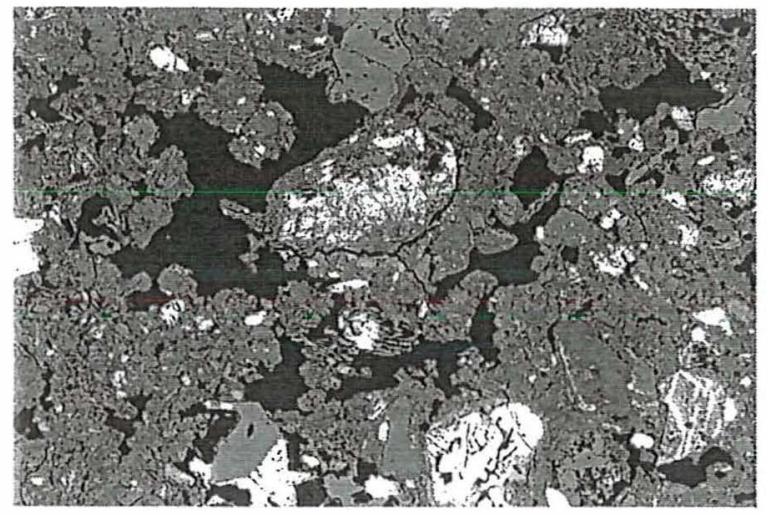

a) T3 alterita

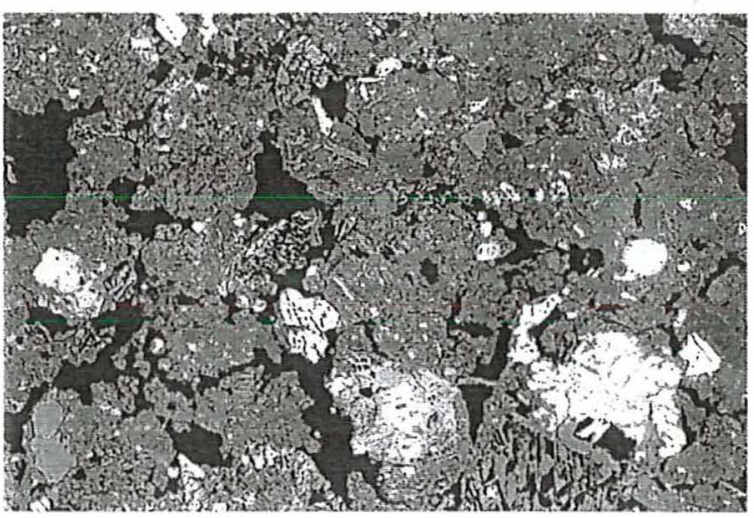

b) T3 alterita

Figura 12: Porosidade mamelonar e policôncava originada na alteração.

A Figura 13a mostra uma organização particular do fundo matricial da alteração apresentando uma porosidade textural de empilhamento, esta organização particular está formada principalmente por sanfonas de caulinita e restos alterados de plagioclásios, piroxênios e minerais ferro-magnesianos. Dentro da mesma alteração, observam-se zonas mais densas formadas a partir de uma reorganização e adensamento do material devido ao aparecimento de um material caulinítico fino rico em ferro que penetra entre o material mais grosseiro, principalmente entre as sanfonas de caulinita, provocando a sua cimentação (Figura 13b, c e d; Tabela 6). A medida que o material fica mais pedogeneizado, ou seja a medida que subimos no perfil, este processo se acentua deixando o fundo matricial denso (Figuras 13e, f). Gradativamente o material grosseiro vai desaparecendo até somente ficar poucos resquícios nos horizontes mais desenvolvidos. A origem deste material fino e rico em ferro é incerta. A Tabela 6 apresenta os resultados microanalíticos das sanfonas grosseiras de caulinita e do material fino rico em ferro. Observa-se que a composição elementar destes dois materiais só diferem no teor de ferro, sendo mais alto no material cimentante. A análise desta tabela indica que deve haver uma interação físico-química entre a caulinita e o ferro que explica este fenômeno. 

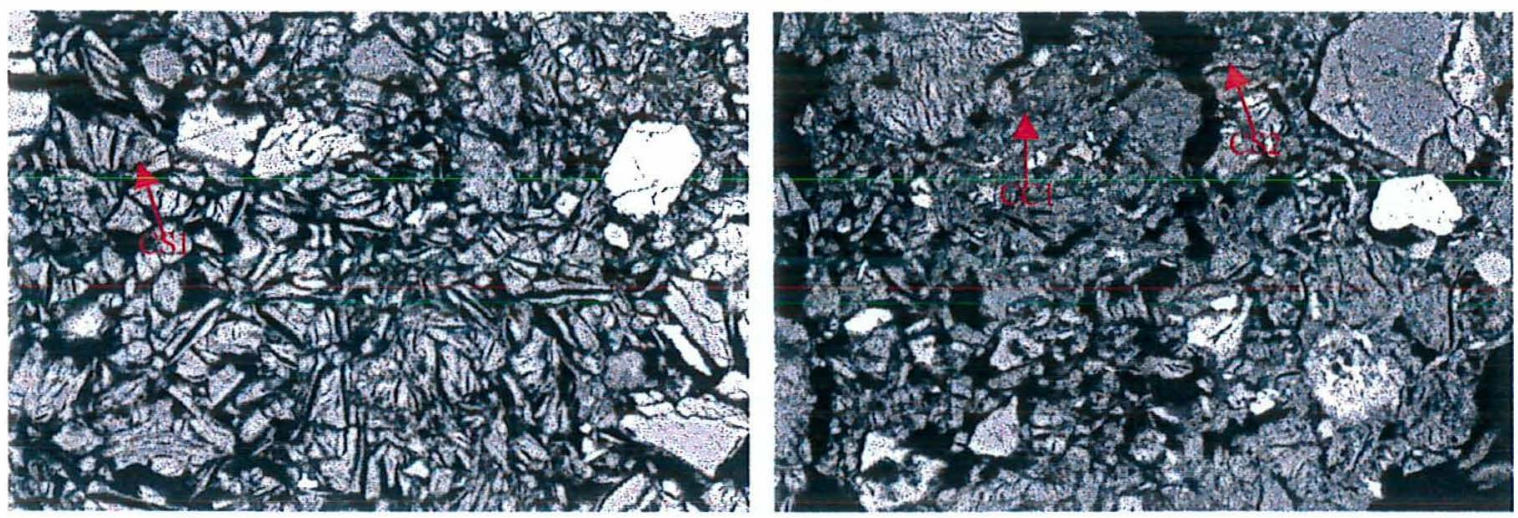

a) T3 alteração

$20 \mu \mathrm{m}$

b) T3 alteração

$20 \mu \mathrm{m}$
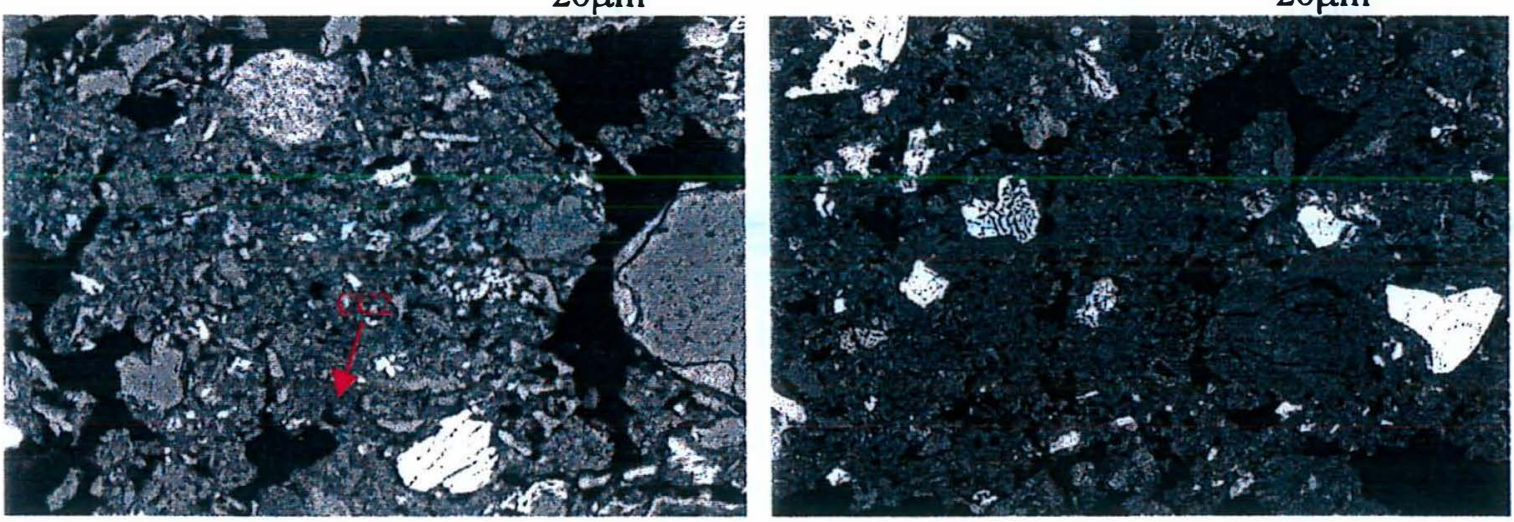

c) T3 alteração

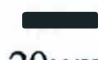

d) T3 alteração

$20 \mu \mathrm{m}$

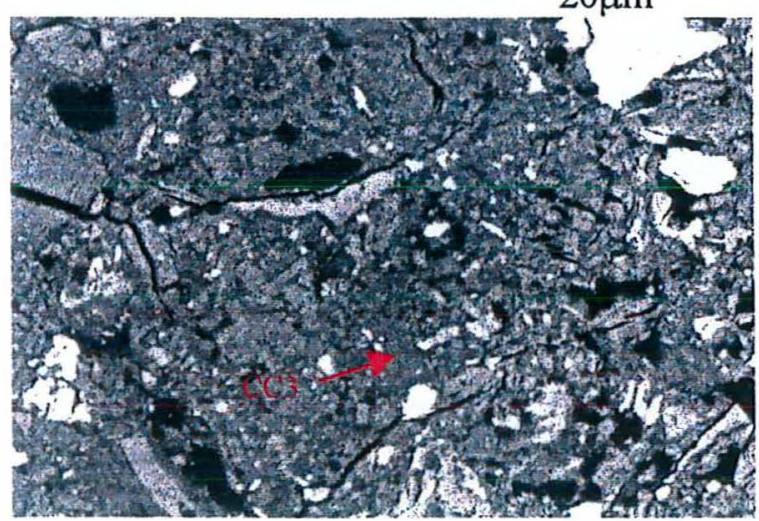

e) T3 BC

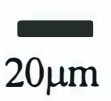

f) T2 Bt1

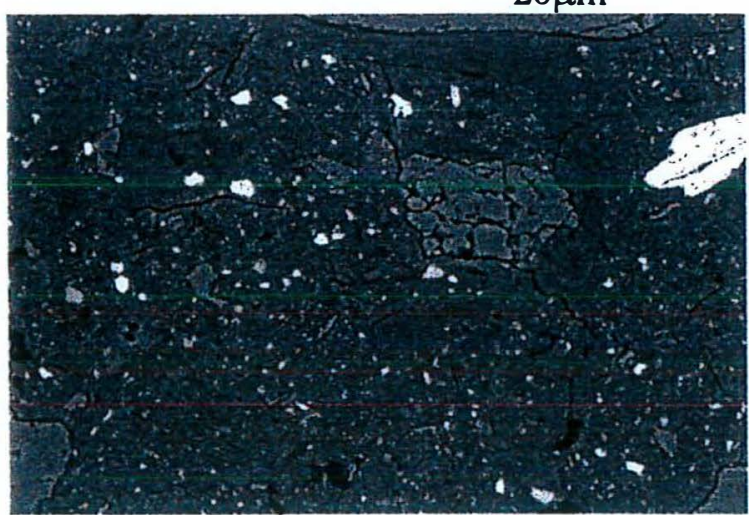

Figura 13: Formação do fundo matricial isótico e rico em ferro. Pontos de microanálise: $\mathrm{CS}=$ caulinita sanfona; $\mathrm{CC}=$ caulinita cimento 
Tabela 6: Composição elementar da caulinita pura e da caulinita fina cimentante.

\begin{tabular}{|c|c|c|c|c|c|c|c|c|c|c|c|c|c|c|}
\hline & $\sqrt{a}$ & $\mathrm{Mg}$ & AI & $\mathrm{Si}$ & $\bar{P}$ & $\mathrm{~S}$ & $\begin{array}{l}\mathrm{Cl} \\
\%\end{array}$ & $K$ & $\mathrm{Ca}$ & 71 & $\mathrm{Cr}$ & $M n$ & $\mathrm{Fe}$ & () \\
\hline \multicolumn{15}{|l|}{ Alteraçăo } \\
\hline Caulinita santona 1 & 0,1 & 0 & 21,4 & 25.9 & 0 & 0 & 0 & 0 & 0,1 & 0 & 0 & 0.1 & 2,6 & 49.4 \\
\hline Caulinita sanfona 2 & 0 & 0,4 & 19.6 & 25,4 & 0,2 & 0,1 & 0,4 & 0,1 & 0,2 & 0 & 0 & 0 & 3 & 48.5 \\
\hline Caulinita cimento 1 & 0 & 0 & 16,5 & 24.5 & 0,4 & 0 & 2.4 & 0.1 & 0,6 & 0.5 & 0,2 & 0 & 8,2 & 46.7 \\
\hline Caulinita cimento 2 & 0,1 & 0.7 & 17,9 & 24,3 & 0,3 & 0 & 1.2 & $-.0<$ & 0,4 & 0,2 & 0 & 0 & 7.8 & 47.2 \\
\hline Caulinita cimento 3 & 0 & 0 & 18,6 & 25,2 & 0,3 & 0 & 1,7 & 0.2 & 0.4 & $.0<$ & 0,1 & 0 & 5.5 & 47.9 \\
\hline
\end{tabular}

A origem dos microagregados é diversa, segundo Buol \& Eswaran (1978), Stoops(1983), Stoops \& Buol (1985), Vidal-Torrado(1994) e Cooper (1996) a origem destes é complexa, resultando da intervenção de mais de um processo de formação. No estudo micromorfológico observou-se uma ampla variedade de formas de microagregados, desde agregados ovais até agregados poliédricos, como sugerido pelos autores acima citados, a origem destes pode ser variada.

O estudo mais detalhado dos horizontes de alteração e dos horizontes $\mathrm{Bw}$ da seqüência estudada, mostrou que a evolução da formação dos microagregados esta intimamente ligada aos processos de reorganização e adensamento do fundo matricial explicado acima. A Figura 14 mostra uma seqüência de imagens que confirma esta idéia. Observa-se nesta sequência que a reorganização do fundo matricial dentro da alterita leva à formação da porosidade policôncava e mamelonar iniciando assim o processo de individualização dos microagregados e aglomerados de microagregados. Um processo de fissuração, evidente nas imagens, ajudaria na individualização dos microagregados.

A presença de cutãs de iluviação, classificados neste caso como ferri-argilãs, foi constatada em todos os perfis estudados, distribuídos principalmente nos horizontes Bt e na parte superior da alterita do perfil 3. Nos estudos micromorfológicos observou-se que estes apresentavam uma orientação forte contínua, uma cor vermelha mais clara que o fundo matricial e estavam distribuídos principalmente dentro da porosidade policôncava e mamelonar e nas fissuras. 

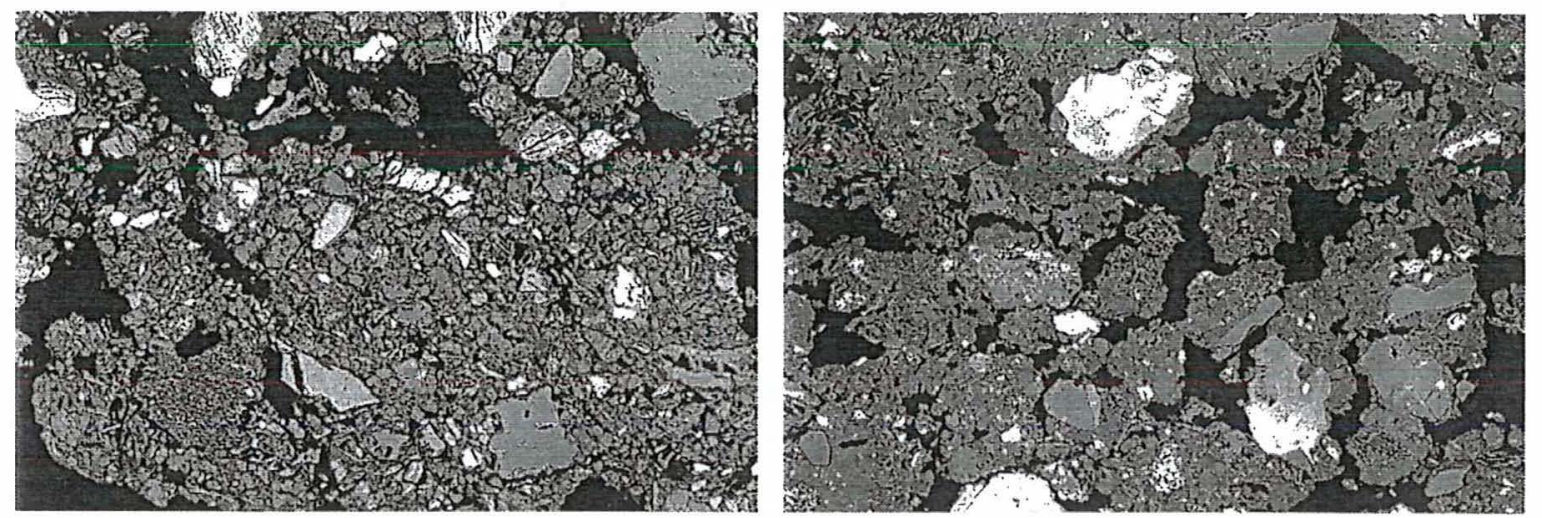

a) T3 alteração

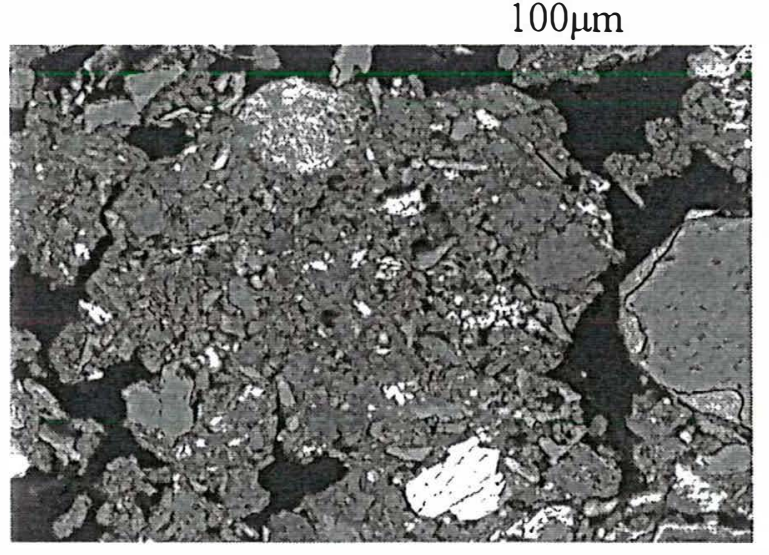

c) T3 alteração

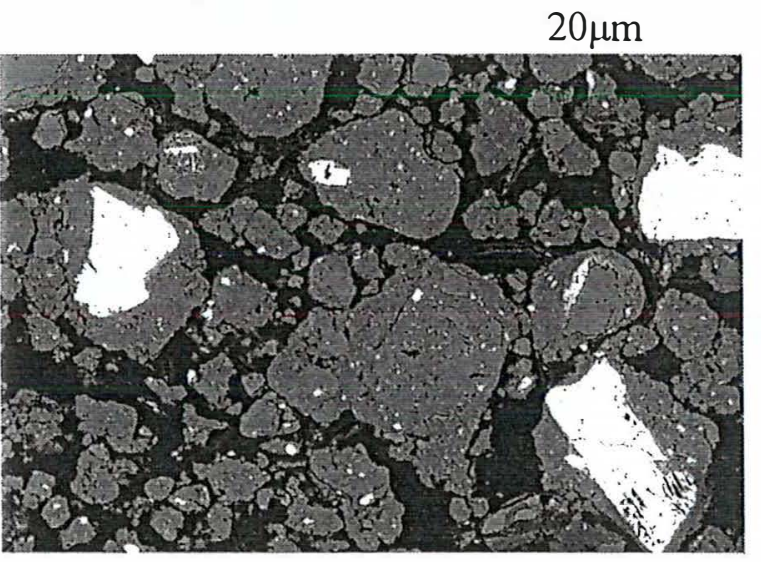

e) T1 Bw

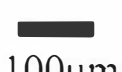

b) T3 alteração

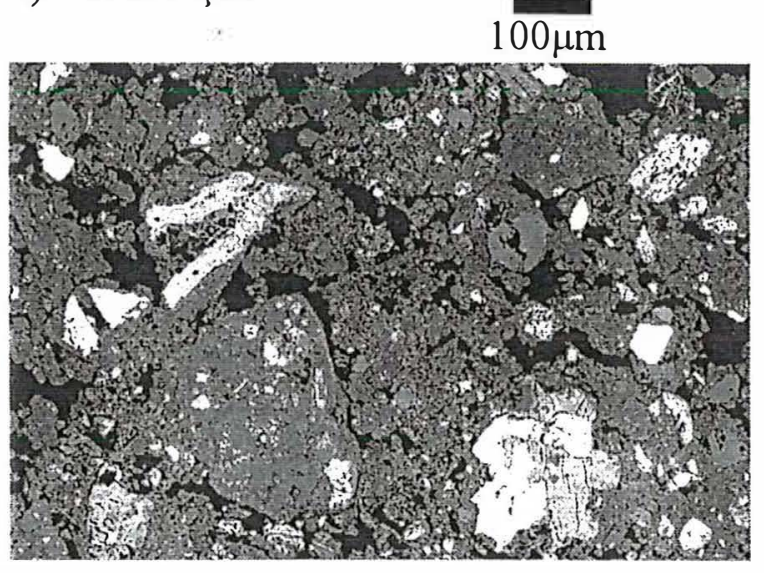

d) T3 alteração

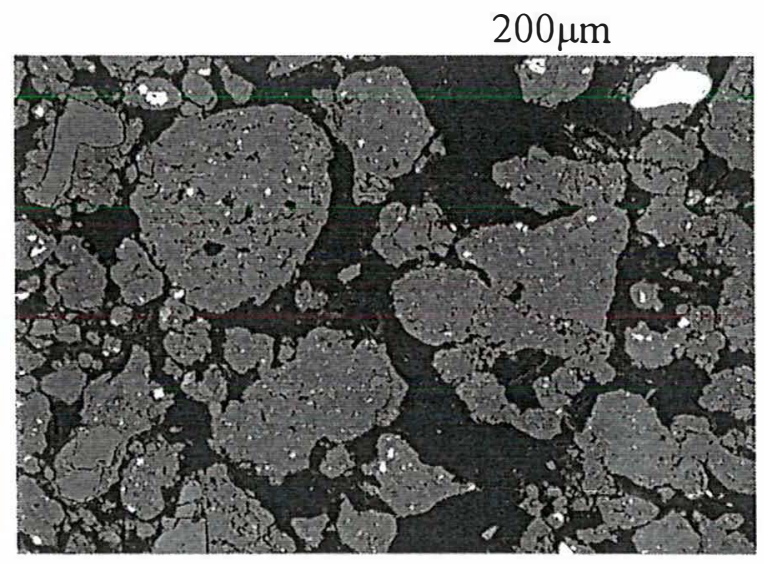

f) T1 Bw

$100 \mu \mathrm{m}$

Figura 14: Imagens mostrando a formação de microagregados. 
O estudo detalhado nas resoluções do microscópio eletrônico de varredura mostrou que os cutãs preenchiam grande parte da porosidade mamelonar provocando uma coalescência do fundo matricial e o conseqüente adensamento (Figura 15). Este processo de deposição, como já foi dito, começa nas parte superiores da camada de alteração. Não foi possível observar uma orientação preferencial das argilas nesta escala. Embora que a maioria dos cutãs apresentou uma orientação forte e contínua na escala do microscópio ótico. Uma grande porção dos ferri-argilãs apresentava-se fissurada. devido às forças de contração e expansão do solo, explicando, desta forma, a orientação manchada destes nas observações com o microscópio ótico.

Foi realizado um estudo comparativo da composição elementar entre os materiais que compõem os ferri-argilãs e o fundo matricial do solo (Tabela 7). Verificou-se que na alterita a composição só variava no teor de ferro, ou seja, os materiais, tanto do cutã como do fundo matricial, eram cauliníticos mas o cutã apresentava mais ferro. A medida que se passa para os horizontes mais pedogenéticos a situação muda. Observa-se que na transição entre a alterita e o horizonte $\mathrm{B}$, o horizonte $\mathrm{BC}$, os dois materiais continuam a ser cauliníticos, mas o teor de $\mathrm{Fe}$ do cutã não muda em relação ao da alterita e o teor é variável deste elemento no fundo matricial. Nos horizontes Bt de subsuperfície, neste caso foi exemplificado com o horizonte $\mathrm{T} 2 \mathrm{Bt} 2$, praticamente não existe diferença entre a composição dos cutãs e o fundo matricial.

Tabela 7: Composição elementar dos cutãs e fundo matricial de três zonas diferentes.

\begin{tabular}{|c|c|c|c|c|c|c|c|c|c|c|c|c|c|c|}
\hline & Na & KE & ता & St & $\mathrm{P}$ & 5 & O & $\pi$ & Ca & $T_{1}$ & $\mathrm{Cr}$ & Tn & $\mathrm{Fe}$ & 0 \\
\hline \multicolumn{15}{|l|}{ Aाteraça } \\
\hline Ferriargilā 1 & 0 & 0.2 & 17.9 & 21,7 & 0.4 & 0 & 1 & 0,1 & 0.3 & 0.4 & 0 & () & 12,2 & 45,5 \\
\hline Ferriargilā 2 & 0.1 & 0.2 & 18,1 & 21.8 & 0.5 & 0.1 & 1.2 & 0.1 & 0.3 & 0,4 & 0 & 0 & 11.3 & 45,8 \\
\hline Fundo matricial & 0 & 0,2 & 18,5 & 24.9 & 0.6 & a) & 2,6 & 0 & 0.3 & 0,1 & 0 & 0.1 & 4.4 & 48 \\
\hline \multicolumn{15}{|l|}{ T3 BC } \\
\hline Ferriargilã & 0 & 0.1 & 17,2 & 20.5 & 0.4 & 0.1 & 0.9 & 0 & 0.4 & 0,5 & - & 0 & 15,3 & 44,4 \\
\hline Fundo matricial I & 0 & 0.1 & 18,2 & 22.8 & 0.3 & 0.1 & 0.8 & 0 & 0.3 & 0,2 & 0 & 0.2 & 10.5 & 46,3 \\
\hline Fundo matricial 2 & 0 & 0.1 & 20,6 & 26.5 & 0,1 & 0 & 0.5 & 0.1 & 0.2 & $\bullet$ & 0 & 0 & 2.3 & 49.6 \\
\hline \multicolumn{15}{|l|}{$\mathrm{T} 2 \mathrm{Bt} 2$} \\
\hline Ferriargilā escuro & 0.1 & 0 & 18.6 & 20.3 & $\bullet 4$ & 0 & 0,0 & - & 0.1 & 0,6 & 0 & (1) & 14.4 & 44.7 \\
\hline Ferriargilä claro & $\bullet .2$ & - & 18,8 & 20.2 & 0.3 & 0.1 & 0.6 & 0 & 0.1 & 0.7 & 0 & 0 & 14 & 43,9 \\
\hline Fundo matricial & 0.3 & 0 & 19,1 & 19.9 & 0.3 & 0.2 & 0.6 & 0 & 0.1 & 0.7 & 1) & 0 & 13.7 & 43,5 \\
\hline
\end{tabular}



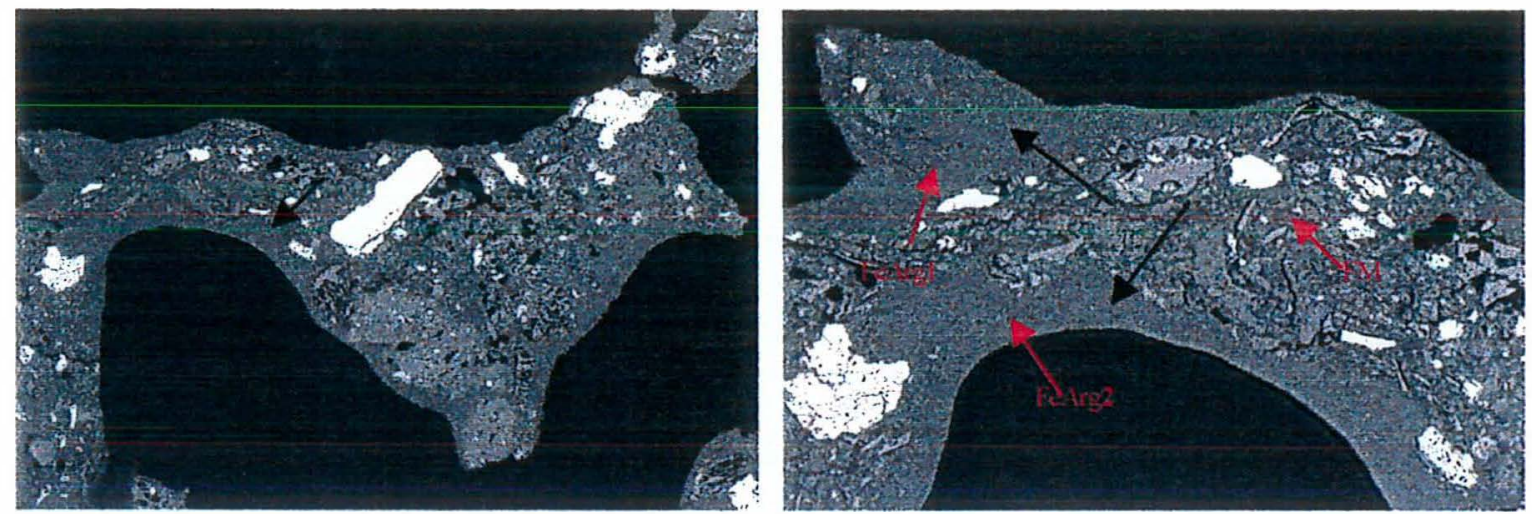

a) T3 alteração

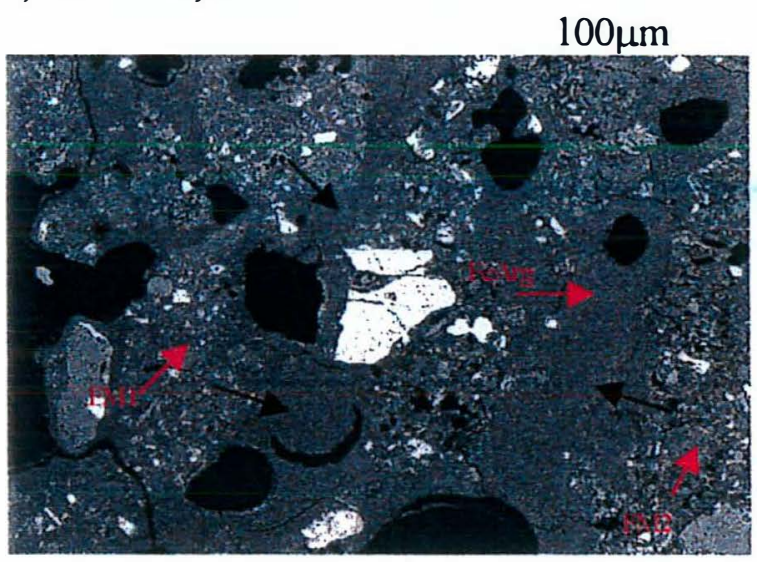

c) T3 BC

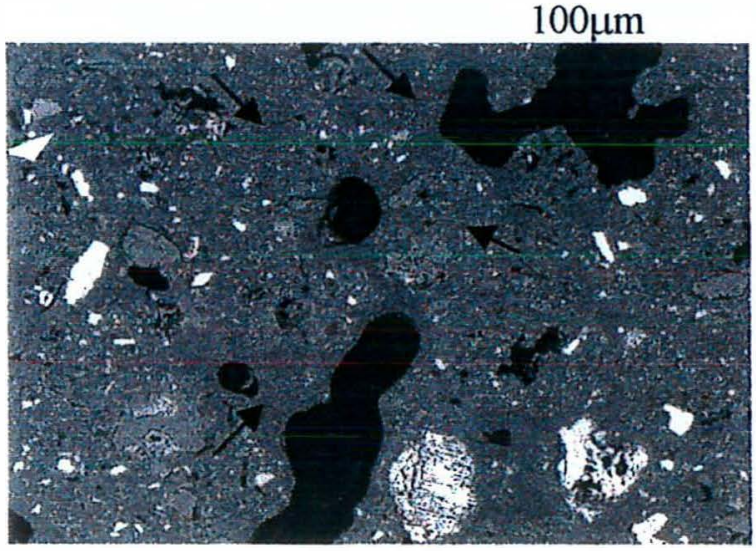

e) $\mathrm{T} 1 \mathrm{Bt} 2$ b) T3 alteração

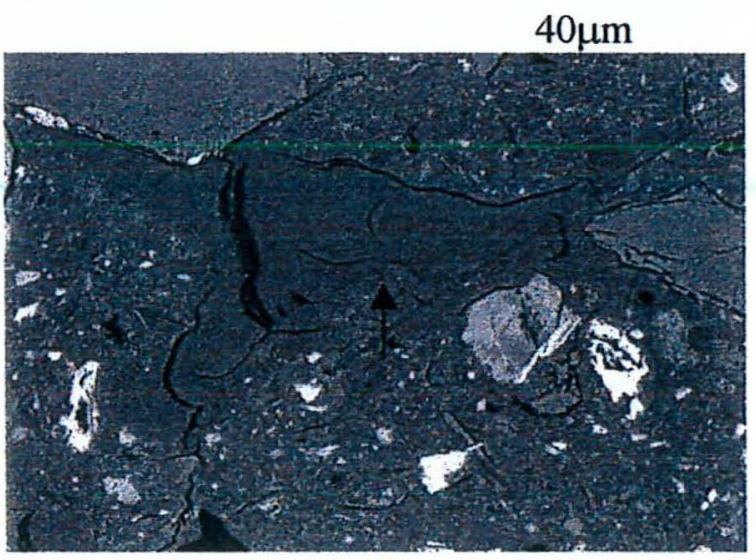

d)T3 Bt3

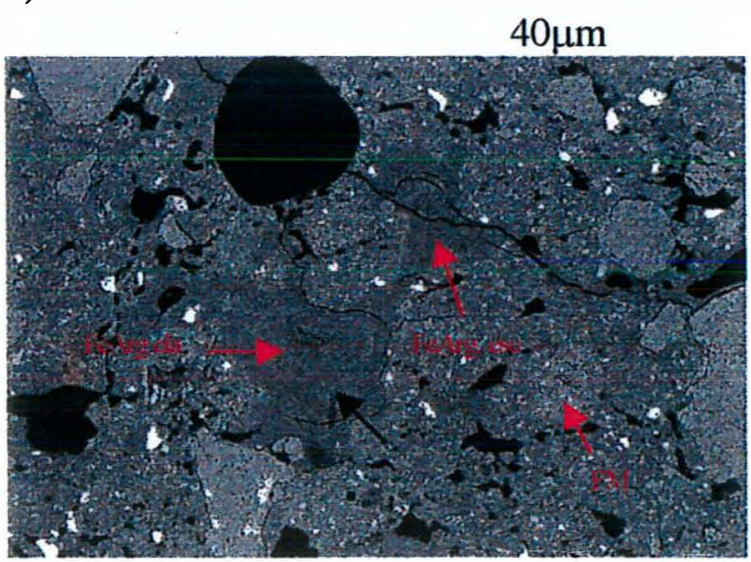

f) $\mathrm{T} 2 \mathrm{Bt} 2$

$100 \mu \mathrm{m}$

Figura 15: Cutãs de iluviação (setas pretas) preenchendo a porosidade e adensando o material. Setas vermelhas, pontos de microanálise: $\mathrm{FeArg}=$ ferri-argilã, $\mathrm{FM}=$ fundo matricial, esc. $=$ escuro, cla $=$ claro. 
A análise desta informação resulta em duas interpretações. Na primeira, devido à semelhança na composição dos cutãs da alterita com os dos horizontes pedogenéticos (Bt) e à diferença destes cutãs com o fundo matricial local, evidencia-se, somente no perfil3, uma translocação e deposição de argila dos horizontes Bt para a alterita. Na segunda, a semelhança da composição dos cutãs e do fundo matricial dentro dos horizontes $\mathrm{Bt}$ de todos os perfis estudados sugere uma redistribuição local da argila associada ao ferro provocando a formação dos ferri-argilãs nos poros policôncavos e mamelonares.

\subsection{Análise do espaço poral por análise de imágens}

Da mesma forma que a descrição pedológica fornece uma caracterização qualitativa da estrutura dos horizontes, ou as medidas densimétricas permitem uma quantificação global da porosidade, a análise de imagens permite descrever com precisão a evolução de macro e mesoporosidade dentro de um perfil. Os principais aportes desta metodologia incluem, por um lado a caracterização individual dos poros, e não mais global da porosidade, e por outro lado, a descrição morfológica tomando em conta critérios essenciais como a forma e a orientação dos poros.

As Figuras 16, 17 e 18 apresentam exemplos de imagens representativas dos horizontes estudados. A seguir apresenta-se uma descrição sucinta da porosidade destes horizontes, para maiores detalhes encontra-se uma descrição mais detalhada no capítulo anterior na seção da análise micromorfológica.

No perfil 1 foram realizados os estudos de análise de imagens nos seguintes horizontes: Bt1, Bt2, Bt2/Bw e Bw.

O horizonte Bt1 (Figura 163a) apresenta uma porosidade dominante mamelonar e arredondada, observando-se também a presença de uma porosidade fissural pequena e de cavidades e canais. A Figura 16b, ilustra a porosidade do horizonte Bt2, nesta pode-se observar duas zonas com porosidade notamente diferentes. Uma zona aonde predominam 

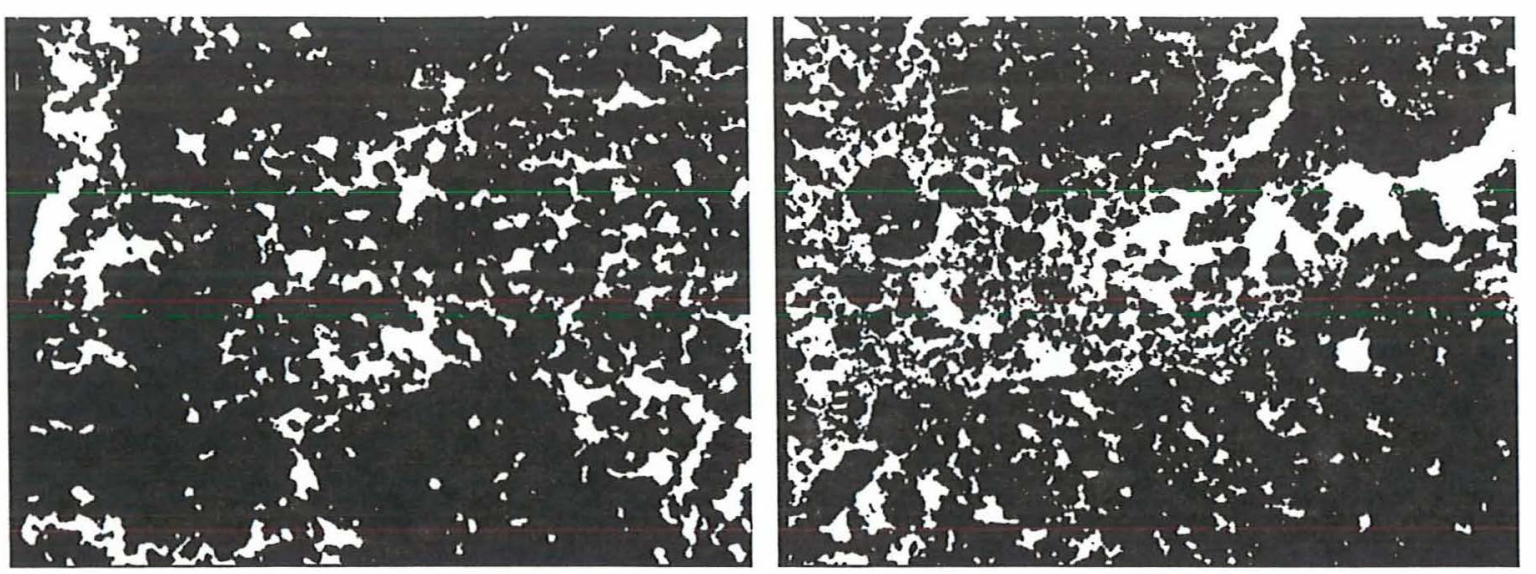

a) $\mathrm{Tl} \mathrm{Bt} 1$

b) $\mathrm{T} 1 \mathrm{Bt} 2$

\section{$1000 \mu \mathrm{m}$}
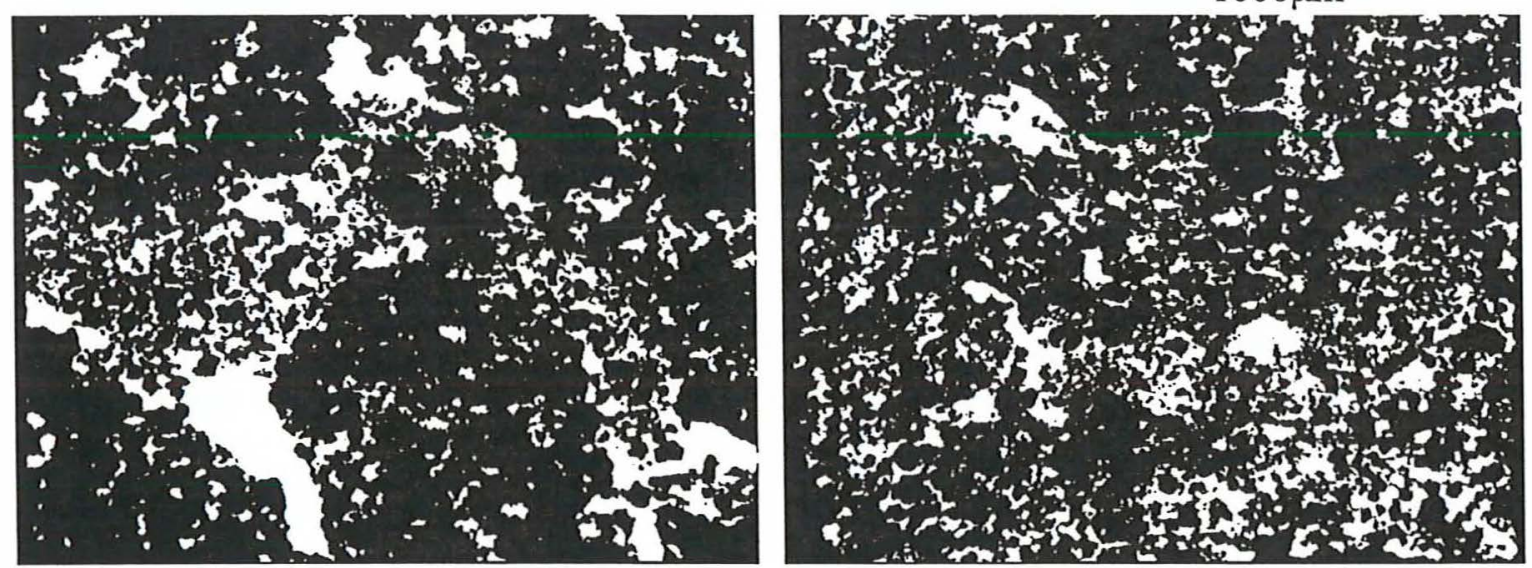

c) $\mathrm{T} 1 \mathrm{Bt} 2 / \mathrm{Bw}$

d) $\mathrm{Tl} \mathrm{Bw}$

Figura 16: Imagens binárias mostrando a porosidade típica dos horizontes do perfil 1 (a porosidade aparece em branco e a fase sólida em preto).

poros de empilhamento e a presença de algumas microfissuras entre os microagregados, e uma segunda zona mais densa onde predomina uma porosidade cavitária, ou seja, arredondada de origem biológica ou mamelonar. O horizonte de transição Bt2/Bw (Figura 16c) também apresenta duas zonas com uma porosidade bem distinta. Uma zona dominante com uma porosidade de empilhamento dominante e algumas microfissuras entre os microagregados, e uma segunda zona mais densa aonde predomina uma porosidade mamelonar e policôncava. Finalmente o horizonte Bw (Figura 16d) apresenta uma porosidade de empilhamento em toda a lâmina apresentando dentro dos aglomerados de microagregados poros mamelonares e policôncavos. 

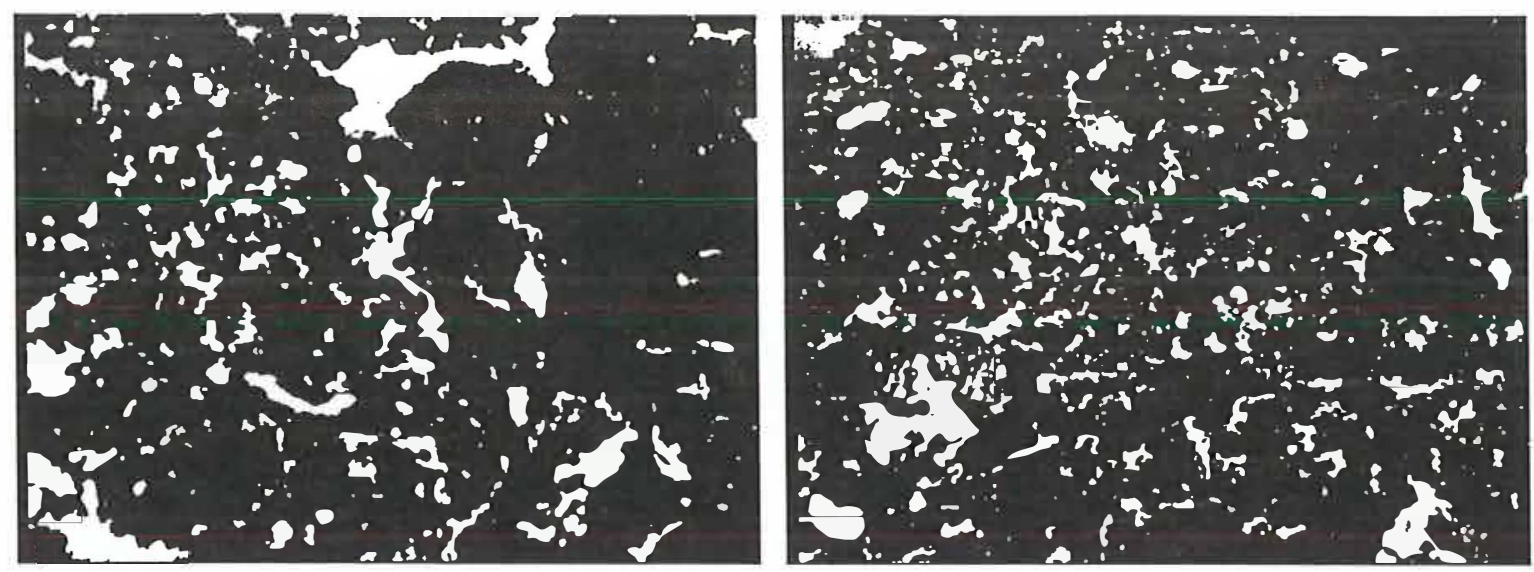

a) $\mathrm{T} 2 \mathrm{Bt} 1$

b) $\mathrm{T} 2 \mathrm{Bt} 2$

$1000 \mu \mathrm{m}$
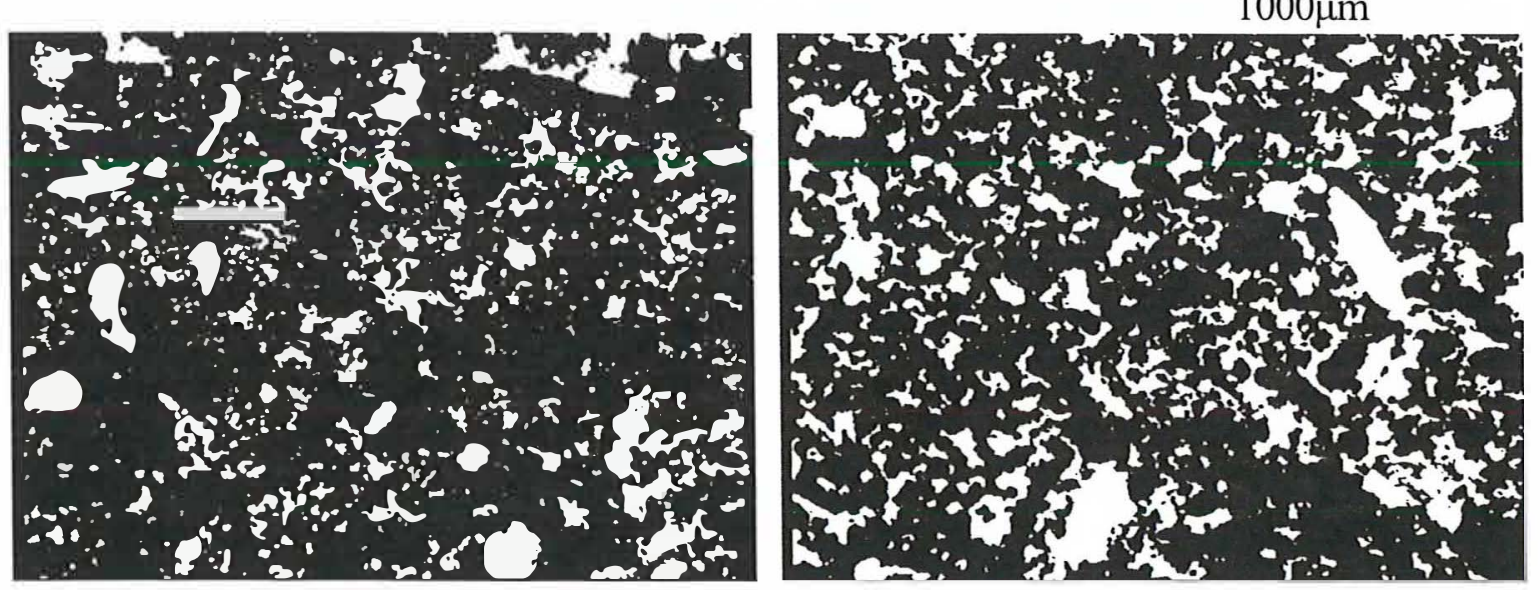

c) T2 Bwl

d) $\mathrm{T} 2 \mathrm{Bw} 2$

Figura 17: Imagens binárias mostrando a porosidade típica dos horizontes do perfil 2 (a porosidade aparece em branco e a fase sólida em preto)..

A porosidade dos horizontes $\mathrm{Bt} 1, \mathrm{Bt} 2, \mathrm{Bwl}$ e $\mathrm{Bw} 2$ do perfil 2 foram estudados utilizando a técnica de análises de imagens (Figura 17).

O horizonte Btl (Figura 17a) apresenta uma porosidade dominante mamelonar, observando-se também a presença de canais e cavidades biológicas e fissuras. A porosidade do horizonte Bt2 (Figura 17b) é composta dominantemente por poros mamelonares de diversos tamanhos e em menor proporção por poros policôncavos. canais e cavidades biológicas e algumas fissuras. O horizonte Bwl (Figura 17c) apresenta uma porosidade dominante policôncava aberta observando-se também a presença de canais e 
cavidades biológicas e microfissuras entre os microagregados. Finalmente o horizonte Bw2 apresenta uma porosidade dominante de empilhamento havendo também em proporção importante a presença de poros policôncavos. Em menor proporção observa-se a presença de canais e cavidades biológicas e microfissuras.

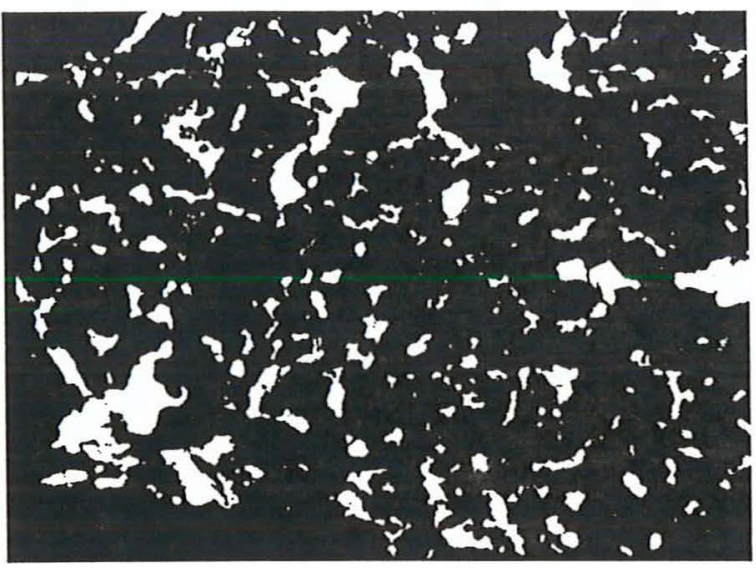

a) $\mathrm{T} 3 \mathrm{Bt} 1$

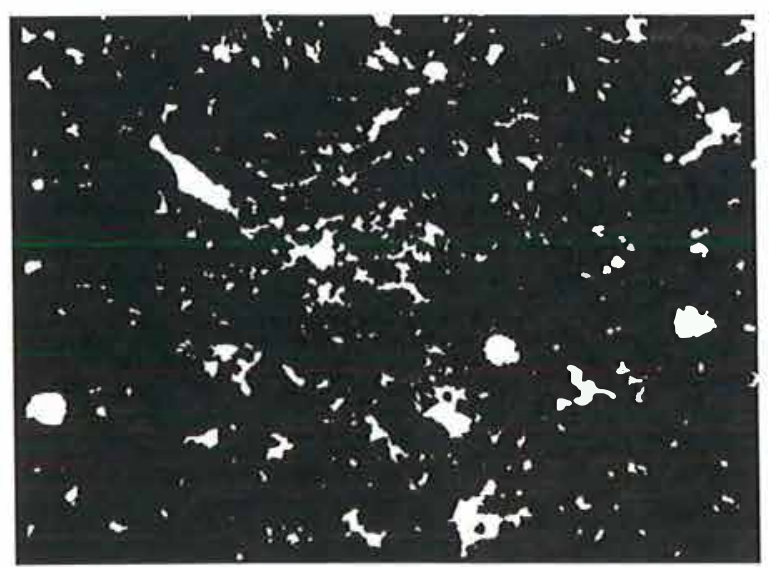

c) $\mathrm{T} 3 \mathrm{Bt} 3$

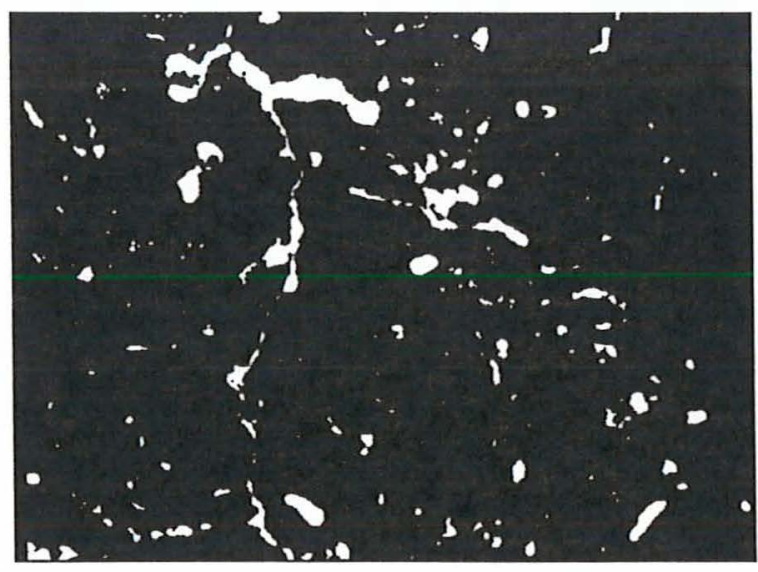

b) T3 Bt2

$$
1000 \mu \mathrm{m}
$$

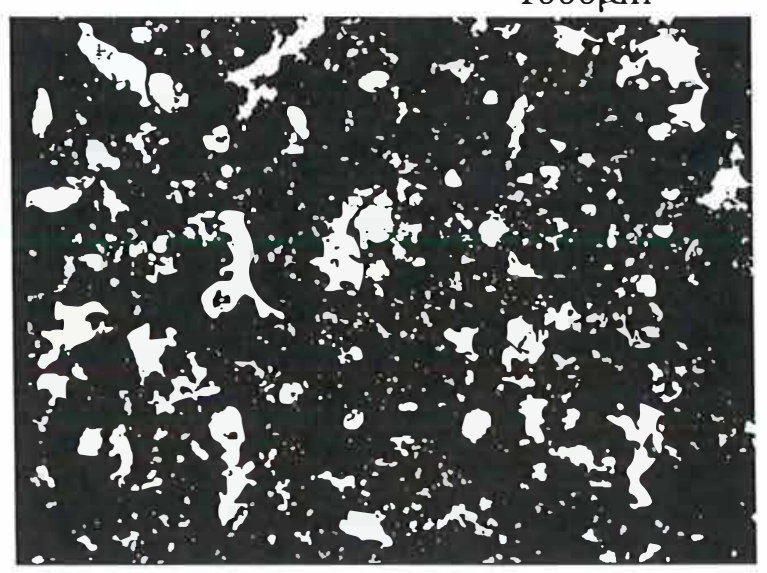

d) $\mathrm{T} 3 \mathrm{BC}$

Figura 18: Imagens binárias mostrando a porosidade típica dos horizontes do perfil 3 (a porosidade aparece em branco e a fase sólida em preto). 
No perfil 3 (Figura 18) foram estudados através desta técnica os horizontes Bt1. Bt2, Bt3 e BC. A porosidade destes horizontes é descrita sucintamente a seguir.

O horizonte Bt1 (Figura 18a) apresenta uma porosidade mamelonar levemente dominante ocorrendo também a presença de proporções importantes de poros fissurais e cavitários. A distribuição da porosidade no horizonte Bt2 (Figura 18b) é semelhante ao Bt1 só que ocupa menos superficie da lâmina. No horizonte Bt3 (Figura 18c) observa-se uma maior proporção de poros mamelonares quando comparado com os outros dois horizontes, observa-se também a presença de poros fissurais e canais e cavidades biológicas. Passando para o horizonte BC (Figura 18d) a dominância de poros policôncavos e mamelonares é importante, havendo a presença também de poros cavitários, canais e fissuras.

\subsubsection{Estrutura do espaço poral}

A estrutura do espaço poral foi quantificada utilizando os seguintes parâmetros: a porosidade total, a distribuição da porosidade e o tamanho e forma dos poróides.

\subsubsection{Porosidade total}

A Figura 19 apresenta os valores da porosidade total medidas nos horizontes na escala de observação definida.

A análise da porosidade média total na trincheira 1, mostra um aumento gradativo da porosidade entre os horizontes Btl e o Bw. Passando de uma porosidade média de 10,4\% no Bt1 para 16,78\% no Bw ou seja a porosidade aumenta de um fator de 1.6. Os horizontes de transição, horizontes Bt2 e Bt2/Bw, apresentam valores médios de 13.65\% e $14,21 \%$, respectivamente. $\mathrm{Na}$ trincheira 2, a diferença entre os horizontes Bt1 e Bw se acentua neste caso, e o fator de aumento é de 2,20, passando de uma porosidade de 7,6\% no Bt1 para 16,73\% no Bw2. Observa-se nesta trincheira uma passagem abrupta entre o 
horizonte Bt2 e Bw1 com porosidades médias de $8,5 \%$ e $15,19 \%$, respectivamente. A última trincheira (trincheira 3) ao contrário do que acontece nas outras duas, observa-se um
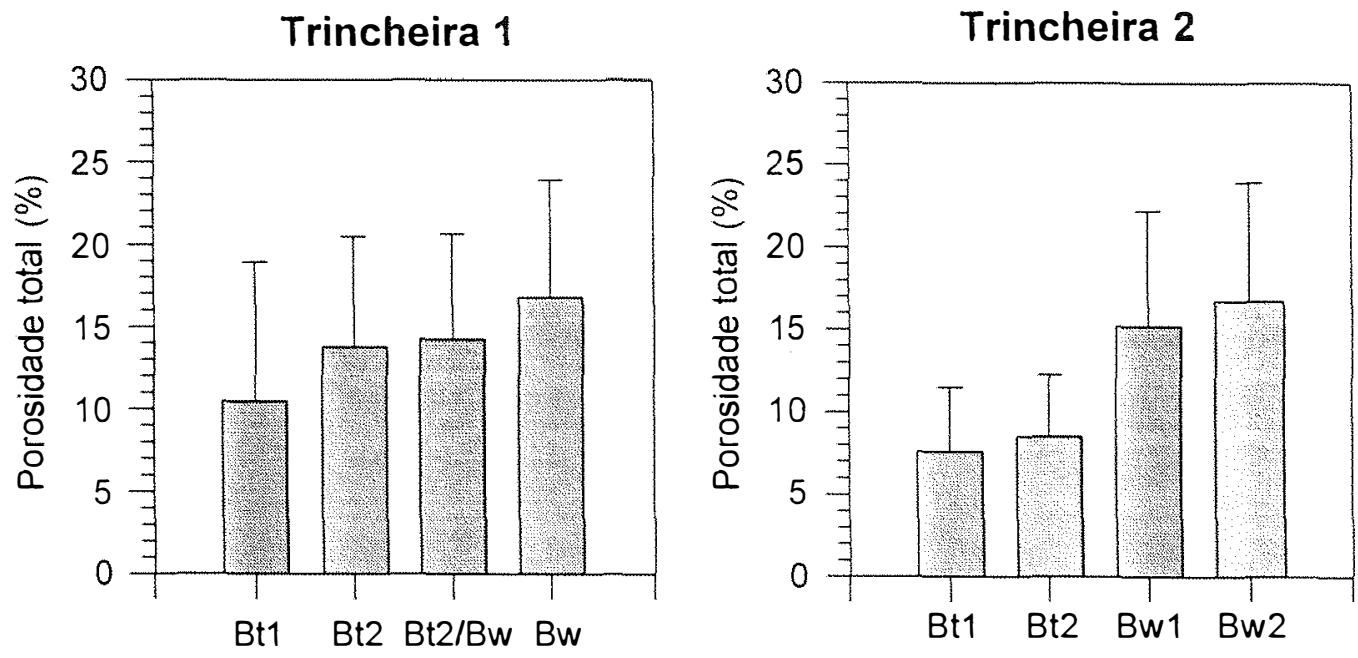

Trincheira 3

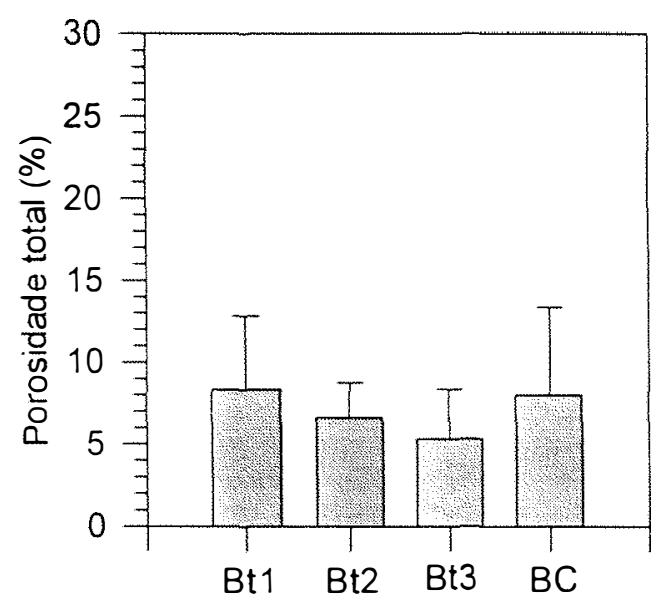

Figura 19:Porosidade total (média e desvio padrão) dos horizontes estudados. 
decréscimo da porosidade até o horizonte Bt3 para logo aumentar no BC. Assim, passa-se de uma porosidade média de $8,36 \%$ no Bt1 para 5,32\% no Bt3 para logo aumentar até $8 \%$ no BC.

Observa-se uma diminuição global da porosidade entre as trincheiras 1 e 3. As maiores mudanças são observadas entre as trincheiras 1 e 2 e a trincheira 3 , ocorrendo uma diminuição na porosidade total em todos os horizontes estudados. Fazendo uma comparação da variação da porosidade entre os horizontes das trincheiras 1 e 3, observamos que entre os dois horizontes Bt1 a porosidade diminui por um fator de 1,11, entre os horizontes Bt2 por um fator de 2.07, entre o Bt2/Bw e o Bt3 por um fator de $2.67 \mathrm{e}$ entre o $\mathrm{Bw}$ e o $\mathrm{BC}$ por um fator de 2,09. Entre as trincheiras 1 e 2 observa-se uma diminuição da porosidade principalmente nos horizonte Bt1 (fator de 1,37) e Bt2 (fator de 1,61), entre os horizontes Bw e Bwl e 2 ocorre uma leve diminuição da porosidade que não chegaria a ser significativa (fator de 1,1 entre o $\mathrm{Bw}$ e o $\mathrm{Bwl}$, e de 1 entre o $\mathrm{Bw}$ e o $\mathrm{Bw} 2)$.

\subsubsection{Distribuição dos poróides}

Os resultados estão apresentados na forma de histogramas de repartiçào da porosidade total em classes de tamanho definidas pelo aumento constante do logaritmo decimal da superfície dos poróides. O tamanho de cada poro individualizado será estimado pela sua área individual, método melhor adaptado para quantificar esta grandeza que o diâmetro dos poros, utilizado quando a porosidade é essencialmente tubular (Edwards et al. 1988).

A análise da Figura 20 mostra que todos os horizontes com exceção do horizonte Bw da trincheira 1, apresentam uma distribuição unimodal da porosidade. Com exceção do horizonte Btl todos os histogramas apresentam uma distribuição unimodal da porosidade bem marcada. O horizonte Bw da T1 apresenta uma distribuição amodal da porosidade. 

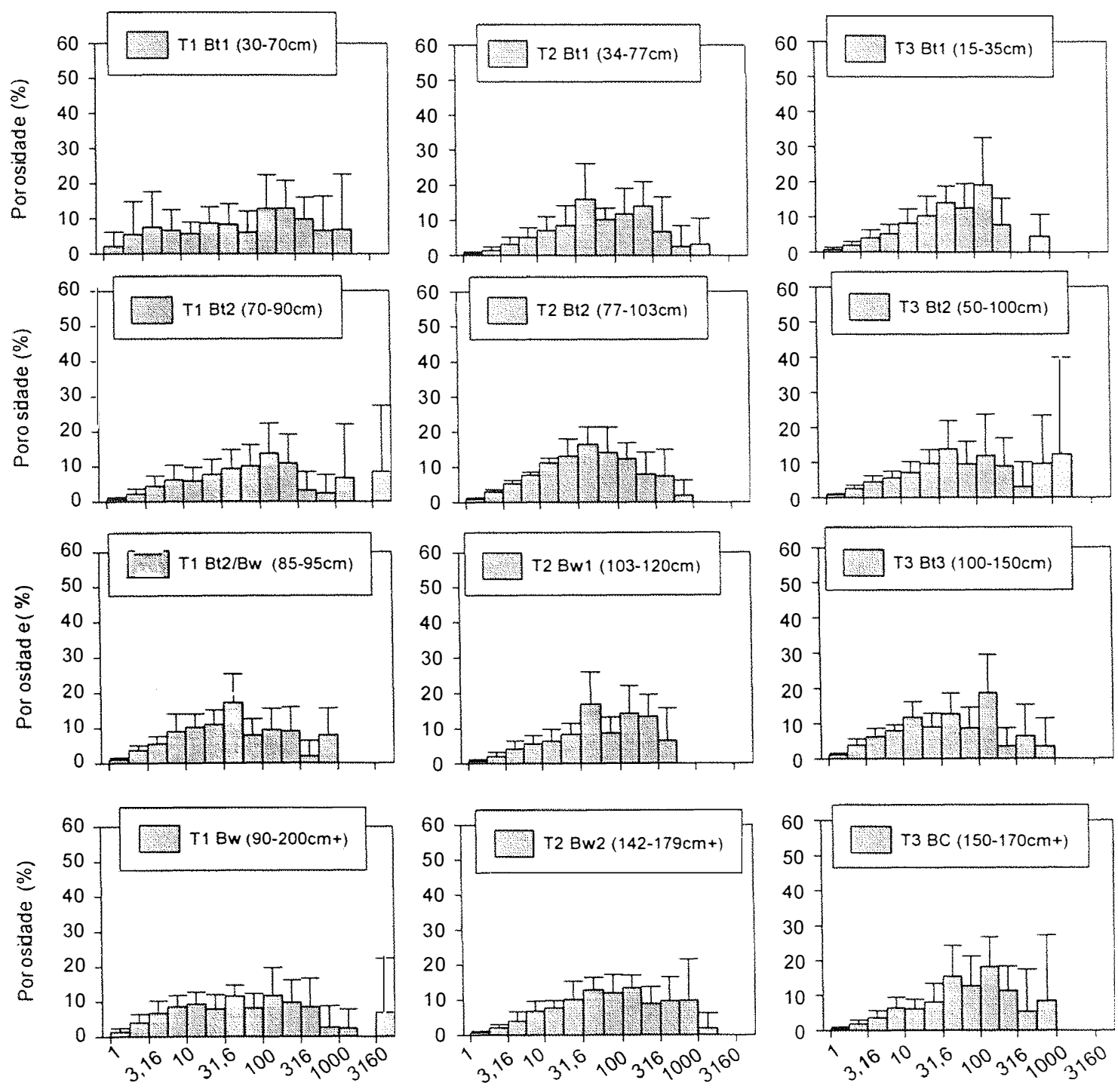

Tamanho dos poróides $\left(\times 10^{-3} \mathrm{~mm}^{2}\right)$

Figura 20:Distribuição da porosidade total dos horizontes por classe de tamanho dos poróides (Média e desvío padrão) 
$\mathrm{Na}$ trincheira 1 podemos separar os horizontes $\mathrm{Bt} 1$ e 2 dos horizontes $\mathrm{Bt} 2 / \mathrm{Bw}$ e Bw. Os horizontes Btl e Bt2 apresentam uma classe de tamanho modal agrupado nos tamanhos de poróides entre 0,1 a $0,316 \mathrm{~mm}^{2}$. Estes se distinguem do $\mathrm{Bt} 2 / \mathrm{Bw}$ pelo deslocamento do tamanho modal para o intervalo entre 0,01778 a $0,1778 \mathrm{~mm}^{2}$. O horizonte $\mathrm{Bw}$, que se caracteriza por uma distribuição amodal, apresenta a maior parte da sua distribuição de poros no intervalo entre 0,00316 e $3,16 \mathrm{~mm}^{2}$.

A trincheira 2 apresenta dois grupos de horizontes classificados segundo a sua distribuição de porosidade, um composto pelos horizontes Bt1, Bt2 e Bwl e outro composto pelo horizonte Bw2. Os três horizontes do primeiro grupo se caracterizam por ter um intervalo modal bem marcado e semelhante, que se encontra entre 0,01778 e $0,316 \mathrm{~mm}^{2}$. Já o horizonte Bw apresenta um intervalo mais estendido cobrindo a faixa entre 0,01778 e $1 \mathrm{~mm}^{2}$.

A última trincheira praticamente apresenta pouca diferença entre as distribuições porais dos horizontes, encontrando-se o intervalo modal em todos eles entre 0,01778 e $0,316 \mathrm{~mm}^{2}$. Somente no horizonte Bt2 que se observa uma extensão deste intervalo que pode alcançar até $1 \mathrm{~mm}^{2}$.

As diferenças mais marcantes entre as trincheiras encontram-se nos horizontes Btl e nos horizontes Bw. No horizonte Btl observa-se que na trincheira 1, a distribuição é mais plana e homogênea havendo um intervalo modal entre 0,1 e $0,316 \mathrm{~mm}^{2}$, enquanto que nas outras duas trincheiras este horizonte apresenta uma moda bem marcada e no intervalo de porosidade entre 0,0316 e $0,316 \mathrm{~mm}^{2}$. Uma pequena diferença é encontrada entre os horizontes $\mathrm{Bt}$ l das trincheiras 2 e 3 , o intervalo modal deste horizonte na trincheira 3 apresenta uma forma assimétrica para a direita.

Nos horizontes Bw e Bw2 das trincheiras 1 e 2 observa-se que a distribuição é bastante semelhante apesar de que o horizonte Bw2 apresenta um intervalo modal mais pronunciado na faixa entre 0,0316 e $0,177 \mathrm{~mm}^{2}$, assemelhando-se em forma às distribuições dos horizontes Bt. É interessante observar que o horizonte Bwl da segunda trincheira apresenta uma distribuição semelhante aos dos horizontes $\mathrm{Bt}$, apesar de que este apresenta uma estrutura microagregada e com aglomerados de microagregados. O horizonte $\mathrm{BC}$ da 
trincheira 3 que apresentava, segundo as descrições micromorfológicas e submicroscópicas. uma incipiente microagregação não apresenta uma distribuição poral que a caracterize. sendo semelhante aos horizontes Bt.

\subsubsection{Tamanho e forma dos poróides}

Os resultados (Figura 21) são apresentados na forma de histogramas de repartição da porosidade total em classes de tamanho $\mathrm{x}$ forma dos poróides seguindo a tipologia definida na Tabela 1 e 2 .

Qualquer que seja o horizonte nota-se que a maior parte da porosidade é devida aos poros Arr que, por outra parte, são essencialmente de tamanho pequeno e médio. Todas as formas de poróides estão representados em todos os horizontes, com exceção dos Comp no horizonte Bt3 da trincheira 3. Estes se diferenciam pelas proporções relativas dos poróides de diferentes classes morfológicas na porosidade total.

$\mathrm{Na}$ trincheira 1 observa-se em todos os horizontes, como já notado anteriormente, que a porosidade que domina é a Arr. A proporção de poros Alon encontrados em todos os horizontes é a mesma, observando-se uma maior presença de tamanhos grandes deste tipo de poros nos horizontes Bt. A porosidade Comp diminui em direção do Bt, com a exceção do horizonte $\mathrm{Bt} 2$ aonde observa-se uma presença importante desta porosidade é de tamanho grande.

A segunda trincheira apresenta, como foi dito anteriormente, uma dominância de poros Arr. A proporção de poros Arr aumenta no sentido Bw-Bt. Os poros Alon apresentam proporções maiores nos horizontes $\mathrm{Bt} 1$ e $\mathrm{Bw} 2$ enquanto que os horizontes Bt2 e Bwl apresentam proporções semelhantes. Neste perfil observa-se claramente a diminuição da porosidade Comp no sentido Bw-Bt, sendo que em todos os horizontes domina a classe de tamanho grande.

$\mathrm{Na}$ última trincheira novamente aparecem os poros Arr como dominantes. O horizonte Bt3 é o horizonte que apresenta a maior proporção destes poros na seqüência 

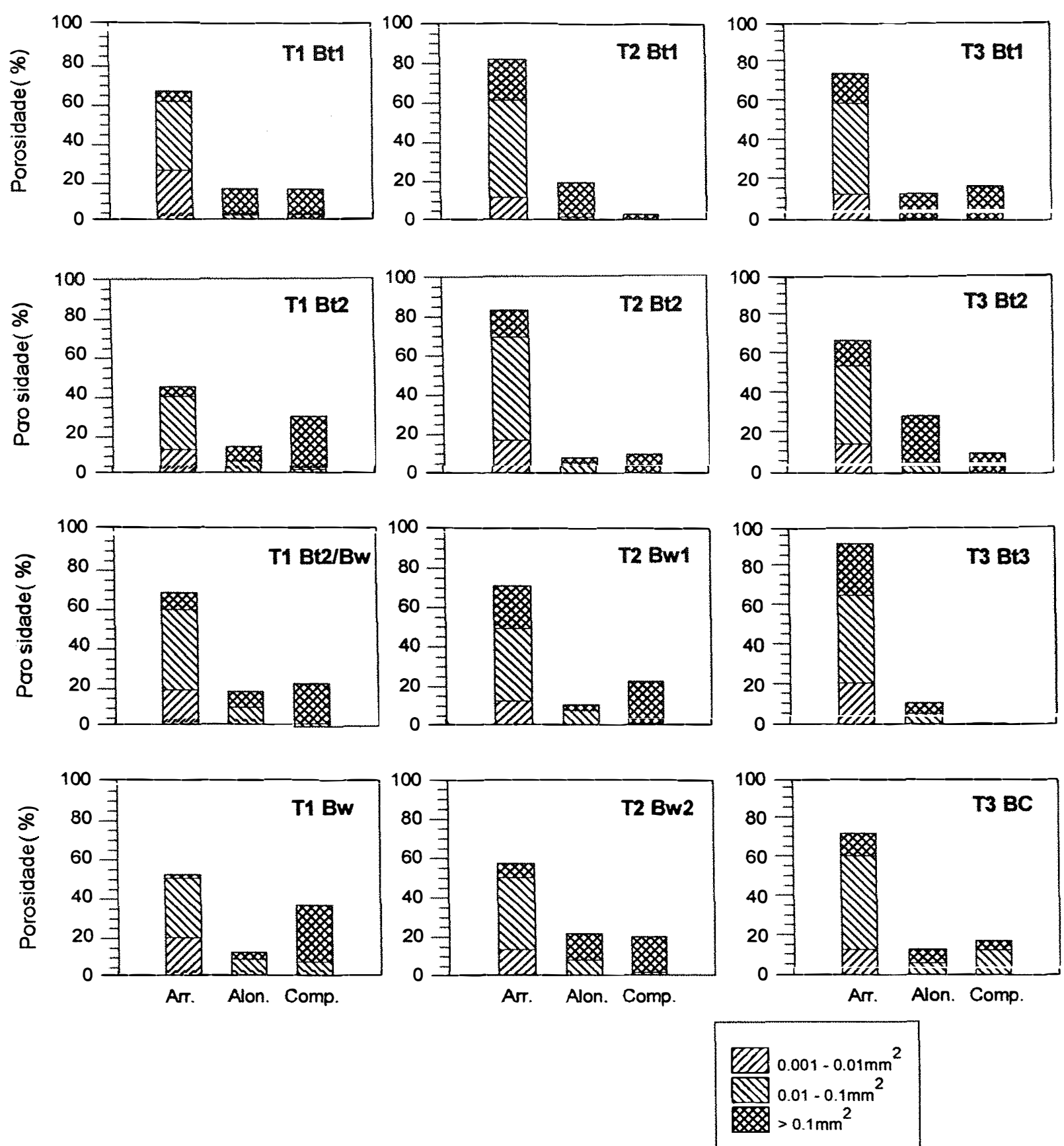

Figura 21: Distribuição da porosidade total segundo a forma e o tamanho dos poróides. Arr=arredondados, Alon= alongados, Comp= complexos. 
toda. Os horizontes Btl e Bt2 apresentam as maiores proporções de poros Alon e os de maior tamanho também, não sendo desprezável a proporção destes nos horizontes Bt3 e BC. Os poros Comp desaparecem completamente do horizonte Bt3, mas os horizontes Bt1 e BC apresentam proporções importantes destes poros. No horizonte BC predominam os poros Comp médios em relação às outras duas classes.

Observa-se que entre as trincheira 1 e 2 a proporção de poros Arr aumenta em todos os horizontes enquanto que a proporção de poros Comp diminui. O mesmo pode-se dizer entre as trincheiras 1 e 3 mas fica menos evidente entre as trincheiras 2 e 3 .

É interessante destacar que a relação poros Arr e poros Comp é inversamente proporcional em todos os perfis, ou seja, onde temos uma proporção da porosidade Comp alta a porosidade Arr é menor, enquanto que onde a porosidade Comp é pouca a proporção da porosidade Arr é alta. Observa-se também, que os poros Alon dos horizontes $\mathrm{Bt}$ apresentam maior proporção das classes de tamanho grande que os horizontes $\mathrm{Bw}$, de transição e BC. A maior parte da porosidade Comp da seqüência encontra-se distribuída dentro da classe de tamanho grande.

\subsubsection{Interpretação da estrutura do espaço poral}

A análise quantitativa do espaço poral destes solos mostrou e confirmou vários processos que foram descritos qualitativamente nas análise micromorfológicas e submicroscópicas. Assim, o adensamento tanto vertical como lateral observado nas descrições micromorfológicas e nos dados densimétricos (Tabela 3) ficou confirmado ao observar que a porosidade total (Figura 19) diminui de forma geral dos horizontes Bw para os Bt nos perfis onde encontramos esta transição e em todos os horizontes a medida que descemos na seqüência, ou seja, quando passamos da trincheira 1 para a 3 .

A separação da distribuição do tamanho dos poros em classes (Figura 20) em dois grupos distintos. um tendo uma distribuição modal e outro amodal, mostra que a evolução da porosidade do solo sofre uma modificação das classes de tamanho pelos processos de adensamento. Esta modificação é gradual e varia com o grau de desenvolvimento da 
estrutura adensada. Uma exceção a esta afirmação é observada no horizonte T3 BC. no qual esta distribuição modal existe mas a origem das classes de poros intermediários estariam-se originando pelos processos físico-químicos de formação de agregados e microagregados, como observados neste horizonte nas descrições micromorfológicas e submicroscópicas, e não pelos processos de adensamento.

Entre os horizontes $\mathrm{Bw}$ das duas primeiras trincheiras observa-se a inexistência de uma diferença significativa entre as suas porosidades totais (Figura 19). Ao analisar os dados das Figuras 20 e 21, onde quantifica-se a distribuição por tamanho e forma dos poros, observam-se distribuições de tamanho e forma diferentes para cada um dos horizontes, apesar de terem a mesma porosidade total e serem classificados morfologicamente dentro do mesmo horizonte diagnóstico. Assim, a variação das distribuições modais entre os horizontes $\mathrm{T} 1 \mathrm{Bw}$ e $\mathrm{T} 2 \mathrm{Bw} 1$ e 2, a maior proporção de poros complexos grandes no horizonte $\mathrm{T} 1 \mathrm{Bw}$ em relação aos horizontes $\mathrm{T} 2 \mathrm{Bw} 1$ e Bw2 e o aumento da proporção de poros arredondados médios e grandes nestes últimos, confirma o adensamento lateral entre os horizontes $\mathrm{Bw}$ devido à transformação de poros de empilhamento grandes (complexos) em poros mamelonares e policôncavos médios e grandes (arredondados) através do processo de coalescência de microagregados, como já evidenciado nas descrições micromorfológicas.

Este mesmo processo de adensamento também acontece na direção vertical entre os horizontes Bw e os horizontes Bt das trincheiras 1 e 2. Este processo é evidenciado pela diminuição da porosidade total neste sentido Bw-Bt (Figura 19), somado à transformação de poros complexos grandes em poros arredondados médios a grandes (Figura 21) pela coalescência de microagregados.

Um outro processo, que pouco tem a ver com a coalescência de microagregados, mas que destacou-se nas descrições micromorfológicas, foram os depósitos de cutãs de iluviação nos poros mamelonares, policôncavos e fissurais dos horizontes $\mathrm{Bt}$, ajudando no processo de adensamento destes. A variação da quantidade, forma e tamanho dos poros entre os horizontes da transição Bt-Bw nos perfis estudados (Figuras 19, 20 e 21) estão, também, ligados a este processo. 
Os poros alongados apresentam proporções variáveis em todos os horizontes (Figura 21). Em todos os perfis observa-se que a proporção de tamanhos grandes desta classe de porosidade cresce dos horizontes Bw/BC para o Bt1. Este aumento gradual do tamanho destes poros nesta direção indica que este tipo de porosidade esta mais desenvolvida nos horizontes mais densos e que o processo de fissuração é mais importante. Este processo de fissuração atuando sobre o material adensado leva à formação dos agregados poliédricos como observado nas descrições micromorfológicas.

Nos horizontes menos densos a porosidade alongada também é expressiva. Nestes predominam os poros de tamanho médio. Durante a análise micromorfológica dos horizontes, observou-se que estes horizontes menos densos (Bt2, Bt2/Bw, Bw, Bw1, Bw2 e BC) apresentavam uma porosidade fissural mais fina que provocava, ou a divisão dos microagregados ou a formação de microagregados poliédricos ou subarredondados a partir de materiais mais densos. A quantificação deste tipo e tamanho de poros nestes horizontes por esta técnica confirmaria este processo de desestruturacão dos materiais mais densos.

\subsection{Dinâmica físico-hídrica do sistema pedológico}

A determinação da condutividade hidraúlica, da curva de retenção, assim como o levantamento sazonal e durante eventos chuvosos do potencial da água na vertente, tem como objetivo conhecer a dinâmica atual do sistema pedológico e conhecer as relações existentes entre a estrutura do solo e o comportamento hídrico do horizonte.

\subsubsection{Condutividade hidráulica de alguns horizontes}

As medidas realizadas com o infiltrômetro a sucção controlada permite separar o fluxo de água nos grandes poros biológicos e inter-agregados do fluxo dentro da matriz do solo (Perroux \& White, 1988; Ankeny et al, 1988) e de quantificar a contribuição dos diferentes compartimentos do espaço poroso no movimento da água (Watson \& Luxmore, 1986; Jarvis et al., 1987; Lin et al., 1997). Se consideramos que o 
espaço poroso se assemelha a uma rede de tubos capilares, pode-se estabelecer uma relação entre o valor do potencial da água do solo e o valor máximo $r$ do raio dos poros ocupados pela água. Desta forma, temos:

$r=-\frac{2 \sigma \cos a}{\varrho g h} \approx-\frac{0.1482}{h}$

sendo : a tensão superficial entre a água e o ar $\left[\mathrm{MT}^{-2}\right], \quad$ : o ângulo de contato entre a água e a parede do poro, : a densidade da água $\left[\mathrm{ML}^{-3}\right], g$ : a aceleração devido à gravidade $\left[\mathrm{ML}^{-2}\right], h$ : a pressão de água $\left(\mathrm{cm} \mathrm{H}_{2} \mathrm{O}\right)$ e $r$ o raio equivalente do poro $(\mathrm{em} \mathrm{cm})$.

Assim aplicando esta equação aos potenciais de $-1,-3,5$ e $-10 \mathrm{~cm} \mathrm{H}_{2} \mathrm{O}$, exclui-se do processo de infiltração os poros de raios equivalentes superiores a 1,5, 0,4 e 0.15mm, respectivamente.

A Figura 22 ilustra as curvas de condutividade hidráulica dos horizontes da transição Bt-Bw dos três perfis estudados.

O exame do conjunto dos valores de condutividade hidráulica mostra que a dispersão das medidas é grande em cada uma das sucções aplicadas. Como dito anteriormente, os poros que vão contribuir à infiltração da água incluem a macroporosidade e parte da mesoporosidade. A macro e mesoporosidade tem geralmente uma origem estrutural e/ou biológica e estão sujeitas a uma forte heterogeneidade espacial, isto pode explicar as forte variabilidades observadas das condutividades hidráulicas.

Observa-se na Figura 22 uma pequena variação da condutividade entre os horizontes principalmente nos perfis 1 e 2. Entre os perfis as variações do $K$ são pouco significativas. 
Perfil 1

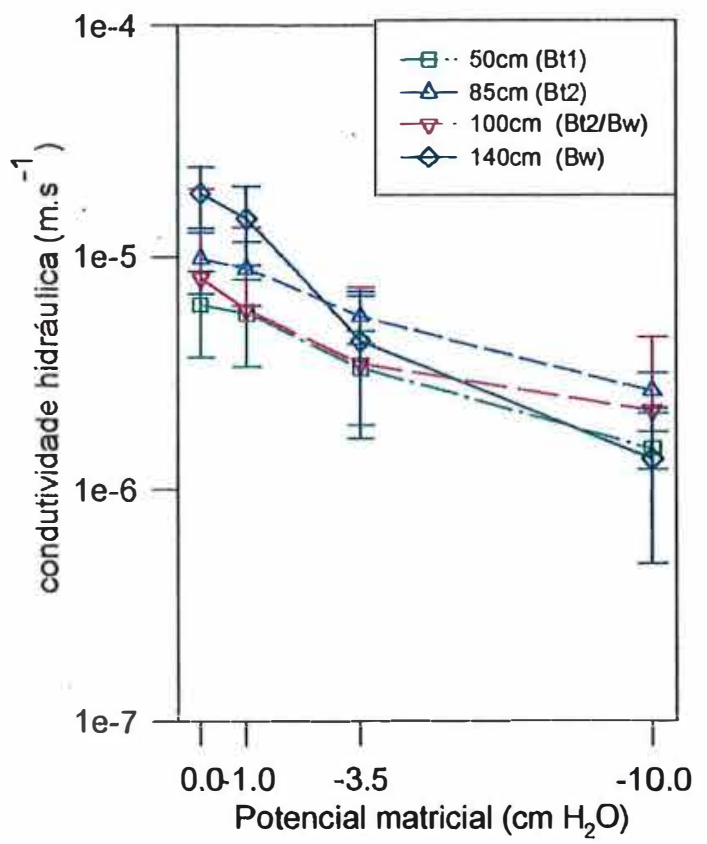

Perfil 2

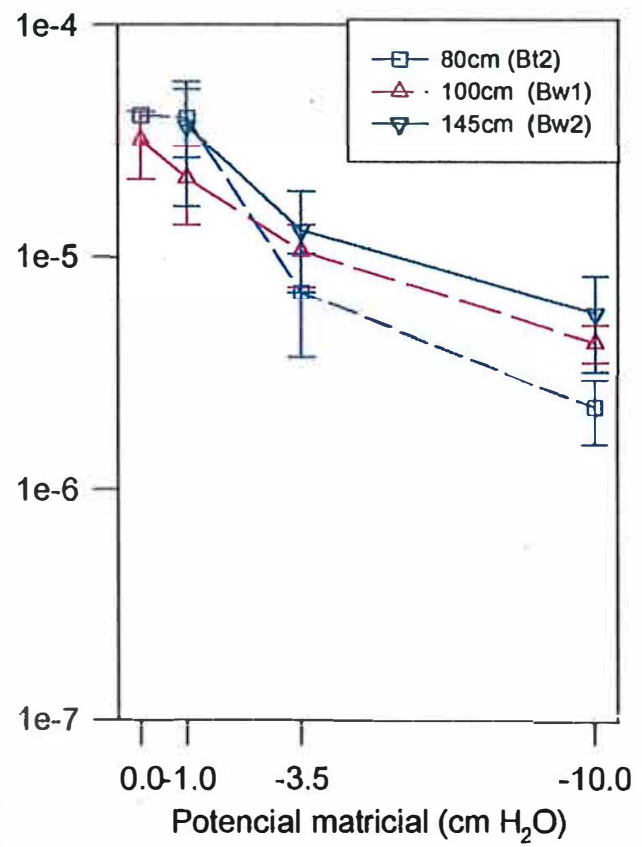

Perfil 3

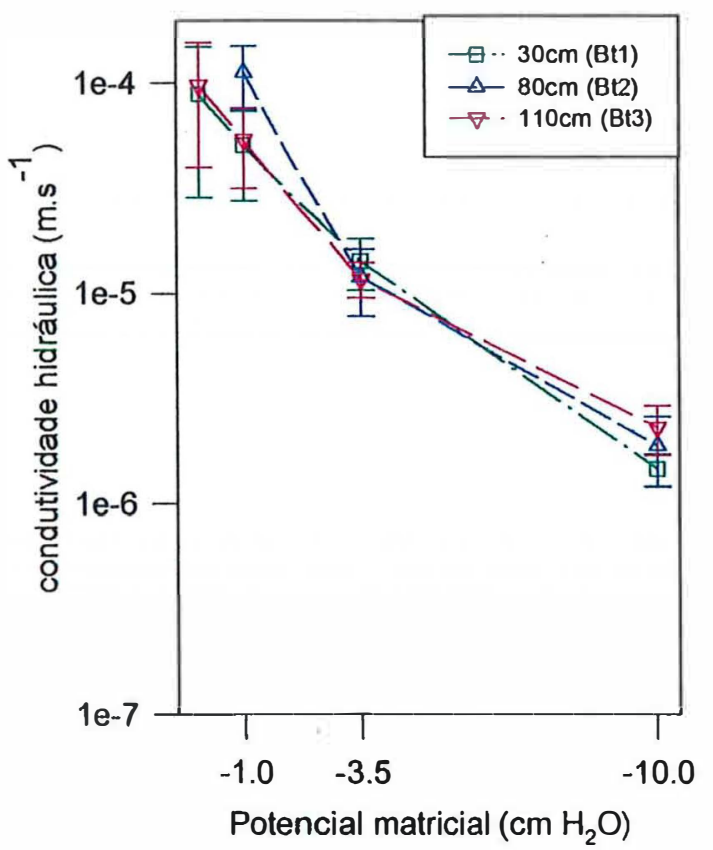

Figura 22: Condutividade hidráulica de alguns horizontes dos três perfis. 
A análise da condutividade pode ser feita em paralelo com os dados apresentados na Figura 21 onde descreve-se a distribuição da porosidade de acordo com a sua forma e tamanho. Em todos os perfis, para os potenciais de -3.5 e -10 de todos os horizontes, não se observam diferenças significativas nos valores de condutividade hidráulica. Estes potenciais referem-se à macroporosidade de menor tamanho e a mesoporosidade de tamanho maior, se compararmos o raio dos poros calculados a partir destes potenciais observa-se que cairia predominantemente na classe de poros média da Figura 21, assim a pouca variablidade na condutividade hidráulica nestes potenciais apresentada em todos perfis pode estar correlacionada com a pequena variação da distribuição desta classe de poros.

Para os potenciais 0 e -1 , as variações observadas são maiores. Estes potenciais referem-se à condutividade hidráulica saturada e à condutividade através de poros de até $1.5 \mathrm{~mm}$ de diâmetro, correspondendo à porosidade grande da Figura 21. As variações desta classe de porosidade são maiores e estão intimamente ligadas com as variações encontradas nas condutividades hidráulicas determinados nestes potenciais. A forma dos poros também influi na condutividade determinada nos potenciais 0 e -1 . Assim um maior desenvolvimento da porosidade fissural (alongada) pode determinar o aumento da condutividade hidráulica, como acontece no horizontes Bt2 do perfil 3, e um maior desenvolvimento da porosidade complexa pode provocar o mesmo fenômeno como observado nos horizontes Bt2 e Bw do perfil 1, e Bw 1 e Bw2 do perfil 2.

\subsubsection{Curvas de retenção da água}

Os resultados referentes às curvas de retenção estão apresentadas nas Figuras 23 e 24. A análise das curvas será feita de duas maneiras, a) analisando as curvas de retenção entre horizontes de um mesmo perfil (Figura 23), e b) analisando as curvas obtidas nas mesmas profundidades em perfis diferentes referentes a horizontes pedológicos ligados genéticamente, como constatado no estudo de análise estrutural da cobertura pedológica (Figura 24). 
As maiores diferenças na forma das curvas entre os horizontes, são encontradas na trincheira 1. Nesta trincheira observam-se dois grupos de curvas, um grupo correspondente aos horizontes $\mathrm{Bt} 2$ e $\mathrm{Bw}$ com um gradiente pronunciado de umidade volumétrica entre os potenciais baixo e altos, e um segundo grupo formado pelos horizontes A, BA e Bt1 muito semelhantes entre eles que apresentam um gradiente médio a baixo entre os potenciais baixos e altos.

$\mathrm{O}$ gradiente pronunciado observado nos horizontes $\mathrm{Bt} 2$ e $\mathrm{Bw}$ em comparação com os horizontes $\mathrm{A}, \mathrm{BA}$ e $\mathrm{Bt} 1$, com um gradiente menos pronunciado, é devido à presença da estrutura dominante microagregada ( $\mathrm{Bw}$ ) ou em aglomerados de microagregados (Bt2) que confere a estes horizontes uma porosidade estrutural mais desenvolvida e uma porosidade textural menos desenvolvida. Apesar de apresentarem formas semelhantes, os gradientes das curvas dos horizontes Bt2 e Bw são diferentes, ocorrendo uma aproximação, por parte da curva de retenção do Bt2, aos horizontes do grupo com gradiente menor. Isto evidência a transformação que esta ocorrendo em nível estrutural e de porosidade verticalmente no perfil.

Observam-se diferenças bem marcadas na umidade volumétrica nos $\mathrm{pFs}$ acima de 2,5 entre a curva do Bw e o resto. A explicação normal para isto seria que, como a estes potenciais a água retida encontra-se principalmente nos poros texturais. esta diferença estaria dada por uma diferença na granulometria dos horizontes. Isto esta parcialmente correto já que existe uma diferença granulometrica entre os horizontes Bt e Bw (Tabela 3), mas é pequena para explicar toda a diferença encontrada. Assim. como demonstrado por Pedro \& Tessier (1983) e Tessier (1984) em experimentos de laboratório, as propriedades de retenção de água pelas argilas podem estar influenciadas pela natureza das mesmas (mineralogia) e pela sua organização (arranjo das particulas de argila entre elas).

Na trincheira 2 observa-se uma ligeira separação devido às diferenças de gradiente entre, um grupo formado pelas curvas de retenção dos horizontes Bt2, Bw1 e 
Trincheira 1

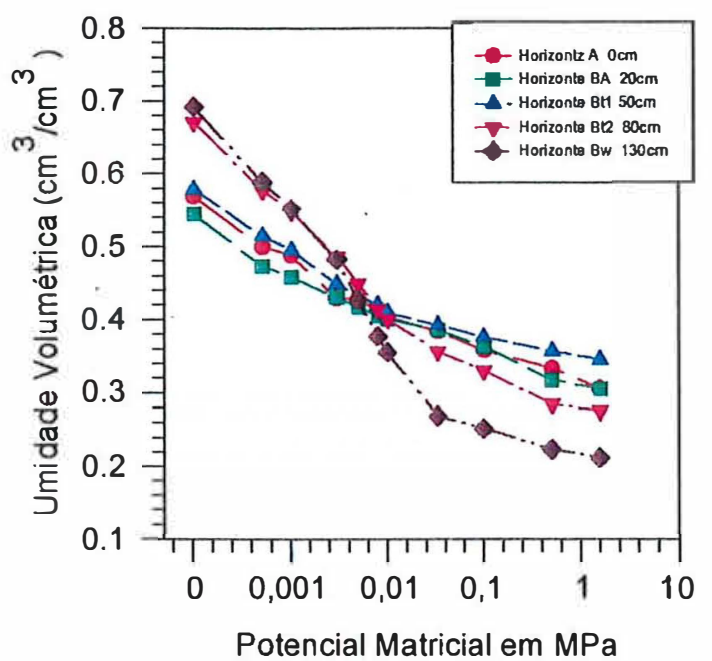

Trincheira 2

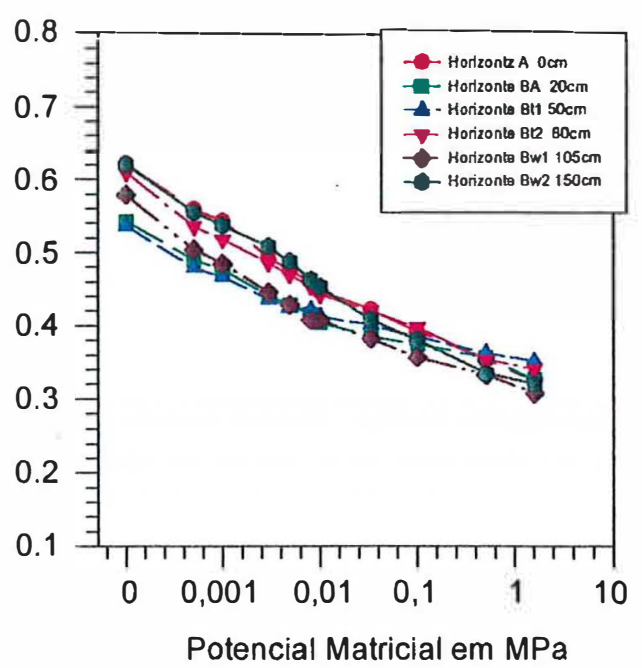

Trincheira 3

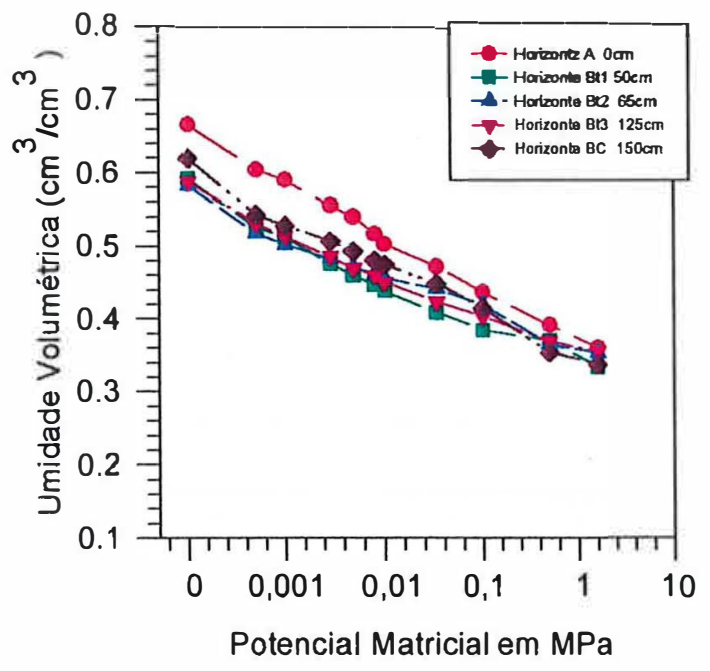

Figura 23: Curvas de retenção da água das três trincheiras. Curvas foram feitas utilizando o log do potencial matricial em MPa. 
Bw2 com um gradiente ligeiramente maior, e um outro grupo formado entre as curvas dos horizontes A, BA e Btl com um gradiente menor. Ocorre, nesta trincheira, uma aproximação da morfologia da porosidade estrutural e textural também. As diferenças na umidade volumétrica nos pFs acima de 2,5 entre os horizontes $\mathrm{Bw}$ e Bt também desaparecem, apesar de observar-se aqui também uma pequena diferença granulométrica entre estes horizontes (Tabela 3). É interessante notar a diminuição drástica das diferenças entre os gradientes dos dois grupos desta trincheira. Isto será discutido a seguir quando da análise das curvas a profundidades iguais.

Finalmente, a trincheira 3 apresenta todas as suas curvas com as mesmas características, não se observando diferenças, no gradiente e na forma entre elas. Todas elas apresentam as mesmas características estruturais e porais. Um pequeno deslocamento na região correspondente à porosidade estrutural foi observada da curva do horizonte $\mathrm{BC}$ em relação aos horizontes Bt. Este fenômeno pode estar relacionado com a presença de uma microagregação incipiente no horizonte BC.

$\mathrm{Na}$ Figura 24 apresentam-se as curvas organizadas por horizontes e profundidades com características semelhantes. Foram escolhidas três profundidades de acordo com a dominância dos horizontes diretamente envolvidos na transição Bt-Bw.

Na profundidade de $50-65 \mathrm{~cm}$ encontramos os horizontes Btl nas trincheiras 1 e 2, e o horizonte Bt2 na trincheira 3, todos eles apresentam características morfológicas e micromorfológicas semelhantes (ver capítulo 1). Observa-se uma diferença de umidade volumétrica nos pFs acima de 1,5 entre os horizontes Bt 1 e Bt2. Esta diferença, numa faixa de potencial que corresponde à porosidade estrutural, é devido ao maior volume deste tipo de porosidade no horizonte Btl (Figura 20). O mesmo fenômeno é observado na curva de retenção do horizonte T3Bt2, neste o maior desenvolvimento da porosidade estrutural identificado pelos valores mais elevados de umidade volumétrica nos pFs mais baixos, é provocado por um desenvolvimento maior de uma porosidade fissural com tamanhos grandes (Figura 21). Observa-se uma evolução lateral principalmente entre os horizontes $\mathrm{T} 1 \mathrm{Bt} 1$ e $\mathrm{T} 2 \mathrm{Bt} 2$ provavelmente devido a uma intensificação do processo de adensamento na $\mathrm{T} 2$. 

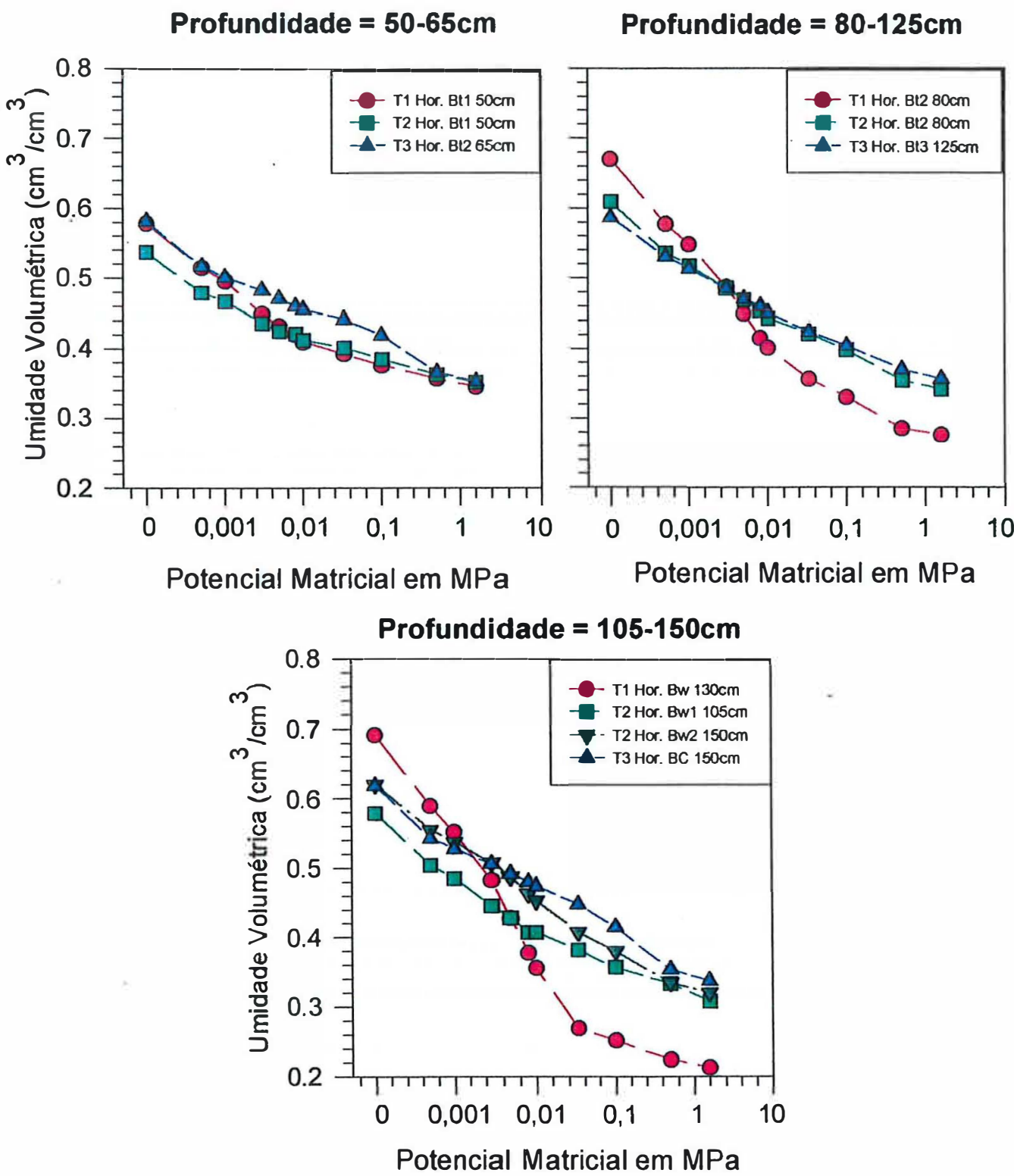

Figura 24: Comparação das curvas de retenção de água entre horizontes com características morfológicas semelhantes localizadas em posições diferentes na sequência. Curvas foram feitas utilizando o log do potencial matricial em MPa 
Entre $80-125 \mathrm{~cm}$, encontram-se os horizontes Bt2 das trincheiras 1 e 2. e Bt3 da trincheira 3. Observa-se nesta profundidade que no horizonte Bt2 da trincheira 10 gradiente é maior e a forma diferente dos outros dois horizontes, que apresentam-se iguais. Em geral o gradiente destas três curvas de retenção são maiores que na profundidade anterior $(50-65 \mathrm{~cm})$.

Nos horizontes mais profundos $(105-150 \mathrm{~cm})$ observa-se que o gradiente aumenta em comparação com as outras profundidades, mas o fato mais importante é a diferença observada entre os horizontes $\mathrm{Bw}$ das duas primeiras trincheiras. $\mathrm{O}$ gradiente da curva do horizonte $\mathrm{Bw}$ da trincheira 1 é marcadamente maior que nos horizontes $\mathrm{Bw}$ da trincheira 2. Mesmo entre o horizonte Bw 1 (mais superficial) e o Bw2 da trincheira 2 observam-se diferenças no gradiente. Esta variação, como explicado na análise dos perfis completos, é devido a uma mudança na porosidade estrutural e textural entre estes horizontes. Este fenômeno foi observado no sentido vertical entre os horizontes das trincheiras, mas ocorre no sentido lateral como vista nesta figura. Não somente no gradiente é que se observam diferenças, na umidade volumétrica a pFs maiores que 2.5, entre o T1Bw e o T2Bw1 e T2Bw2, também encontram-se diferenças importantes, devido neste caso a uma diferença no arranjo das partículas de argila já que estes horizontes apresentam texturas semelhantes. $\mathrm{O}$ horizonte $\mathrm{BC}$, que apresenta uma estrutura microagregada incipiente, apresenta uma curva de retenção semelhante à curva do T2Bw2.

A análise das Figuras 23 e 24 confirmou a mudança de porosidade tanto estrutural como textural entre os horizontes. Esta mudança ocorre tanto no sentido vertical (entre horizontes) como lateral (dentro de horizontes de caracteristicas semelhantes através da sequência de solos). A explicação para esta mudança seria o processo de adensamento pela coalescência de microagregados observado claramente durante as descrições micromorfológicas, sub-microscópicas e também nos estudos da porosidade através da análise de imagens. Não é somente este processo que intervém neste rearranjamento da estrutura e porosidade entre os horizontes Bt. A mudança de arranjo pode estar explicada, também, pela iluviação de argila, que preenchendo a porosidade, provoca um adensamento e consequentemente uma mudança do 
comportamento hídrico do horizonte. Alem da mudança nas características estruturais dos horizontes, ficou claro depois da análise da retenção de água, que o processo de adensamento também provoca mudanças no arranjo das partículas de argila dos horizontes mais densos ou em vias de adensamento.

A comparação entre as Figuras 23 e 24 com a Figura 20 que ilustra a distribuição da porosidade em classes de tamanho, mostrou que os horizontes que apresentavam curvas de retenção com um baixo gradiente, ou seja. os horizontes $\mathrm{Bt}$, apresentam uma distribuição da porosidade unimodal, enquanto que aqueles horizontes com curvas de retenção da água com gradientes mais pronunciados apresentam distribuições amodais (caso do T1Bw). Existem situações intermediárias, como no caso do T1Bt2, onde o gradiente da curva de retenção é relativamente grande apesar de apresentar uma distribuição unimodal da porosidade. Neste caso observa-se uma porosidade importante nos tamanhos maiores de $1000 \mathrm{~m}^{2}$, que apresentam a forma de poros complexos (Figura 21), isto explicaria o comportamento intermediário da curva de retenção deste horizonte. Um outro caso é o horizonte T2Bw2, que apresenta uma distribuição da porosidade unimodal incipiente, mas que ainda conserva as características de uma pseudo distribuição amodal dos horizontes Bw. Estas evidências reforçam o dito anteriormente a respeito do processo de adensamento por coalescência de microagregados como processo principal na transformação entre os horizontes BtBw.

Observou-se neste capítulo uma relação bastante estreita entre os dados levantados das análises micromorfológicas e das análises de imagens com os dados de retenção de água. Desta forma a utilização de ferramentas morfológicas tanto qualitativas como quantitativas permitiria com um grau de precisão bastante elevado inferir o comportamento hídrico do solo.

\subsubsection{Variações sazonais do potencial total no solo}

Apresentam-se, nas Figuras 25, 26, 27 e 28, as medidas de potencial total resultantes das medições feitas nas quatro estações tensiométricas localizadas na 
sequência estudada (Figura 5) entre os meses de outubro/97 e março/98. Os espaços vazios entre datas sucessivas correspondem a períodos onde os tensiômetros apresentaram problemas por estarem no limite da sua utilização.

Os dados tensiométricos referentes à estação 1 estão apresentadas na Figura 25. Esta estação localizou-se no topo da sequência onde observa-se o máximo desenvolvimento do horizonte $\mathrm{Bw}$ (ver descrições morfológicas da trincheira 1) (Figura 5). As profundidades crescentes dos tensiômetros correspondiam nesta estação aos horizontes $\mathrm{A}, \mathrm{BA}, \mathrm{Bt} 1, \mathrm{Bt} 1 / \mathrm{Bt} 2, \mathrm{Bt} 2, \mathrm{Bt} 2 / \mathrm{Bw}$ e $\mathrm{Bw}$, respectivamente.

Os tensiômetros a partir de $60 \mathrm{~cm}$ da estação 1 mostravam que o solo estava bem seco no fim da época sem chuva (outubro/97), encontrando-se no limite de medida dos tensiômetros. Somente os tensiômetros superficiais mediram as variações de potencial devido às primeiras chuvas. Num período relativamente curto ( 1 mês) após o começo da estação das chuvas, os horizontes sub-superficiais, por ordem de profundidade, foram aumentando o seu potencial total até atingir um patamar entre -100 e $-300 \mathrm{~cm}$ de coluna de água. Durante todo este período os horizontes mais superficiais apresentaram potenciais maiores que os mais profundos. Os horizontes que sofreram mais flutuações foram os horizontes A e BA devido à alta influência dos processos de evapotranspiração e absorção de água pelas plantas. Nos horizontes diretamente envolvidos na transição Bt-Bw observaram-se pequenas modificações no seu estado hídrico no decorrer deste período. As flutuações mais importantes observadas nesta transição ocorreram no horizonte Btl (tensiômetro de $60 \mathrm{~cm}$ ) após um período de seca durante a segunda quinzena do mês de janeiro, os outros horizontes também apresentaram flutuações mas foram todos da mesma ordem de magnitude. Os maiores potenciais totais foram atingidos em fevereiro, o mês mais úmido deste período. para depois diminuir gradualmente uma vez que começaram a diminuir as chuvas. Nenhum dos horizontes saturou-se completamente mesmo após a chuva do dia 16/2.

A estação tensiométrica 2 estava localizada na metade do caminho entre as trincheiras 1 e 2 (Figura 5), apresenta a mesma sequência de horizontes que a estação 1 em relação à profundidade dos tensiômetros mas o relevo apresenta neste local uma pendente um pouco mais pronunciada. Os dados estão apresentados na Figura 26. 

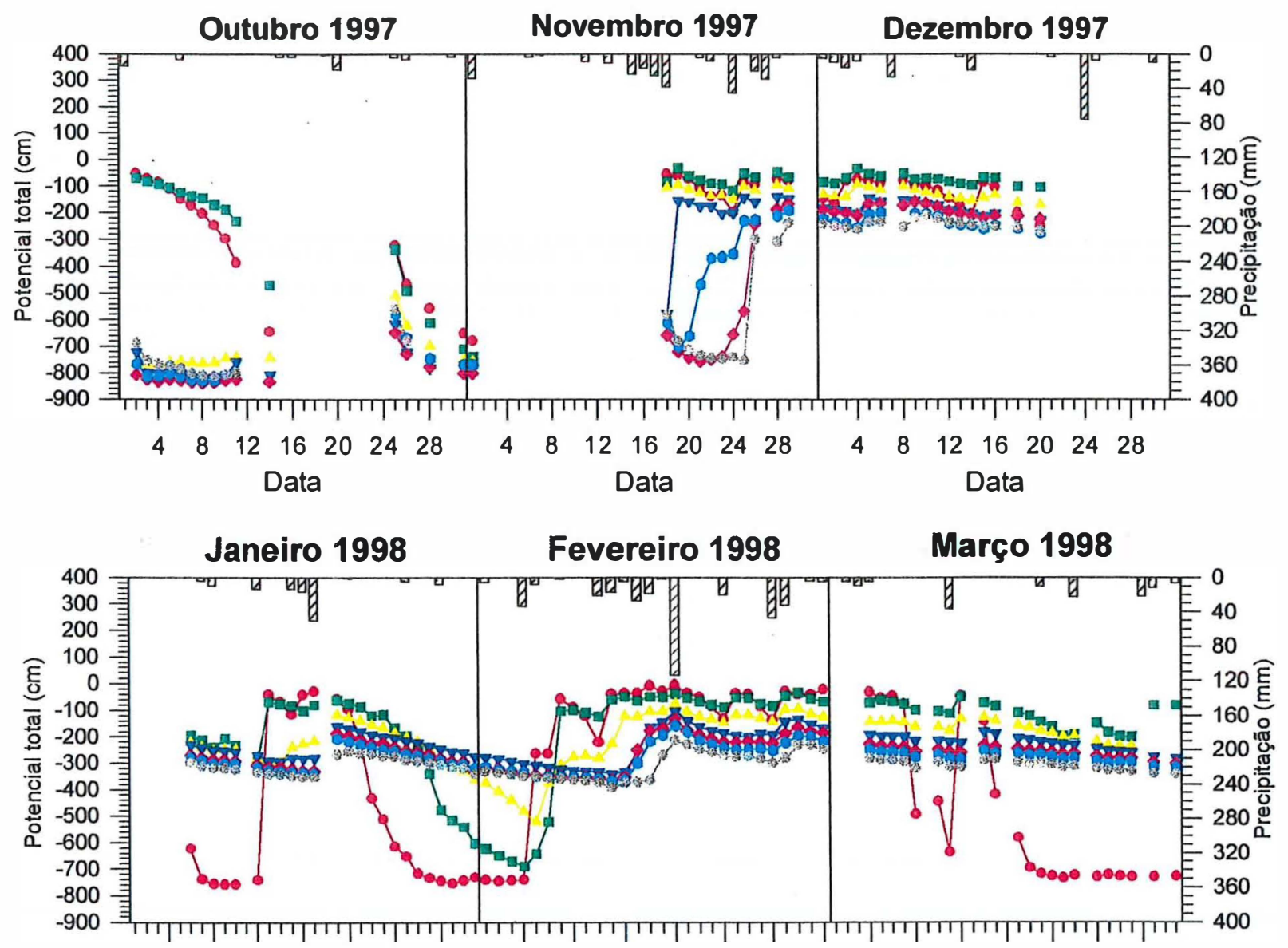

Data

Data

\section{Data}

Figura 25: Variações do potencial total do solo entre outubro/97 e março/98 da estação 1. 


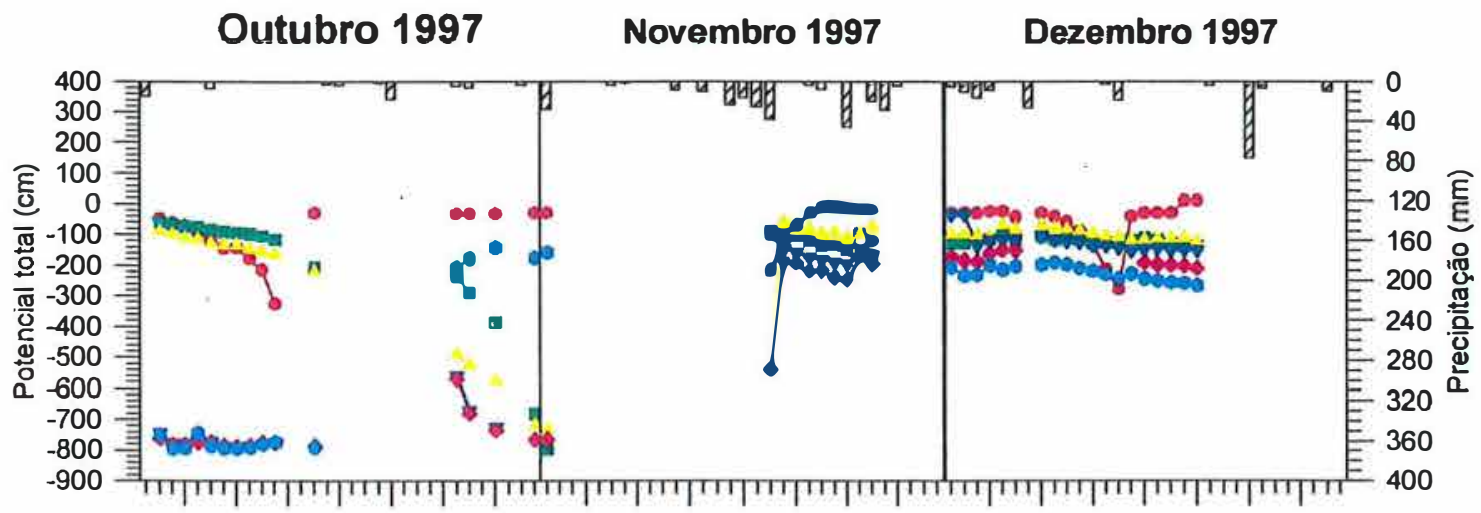

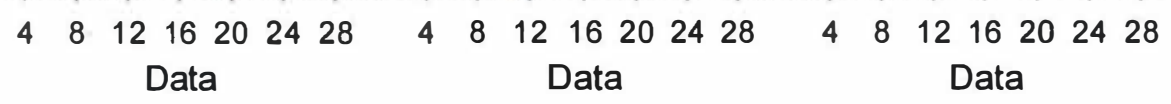

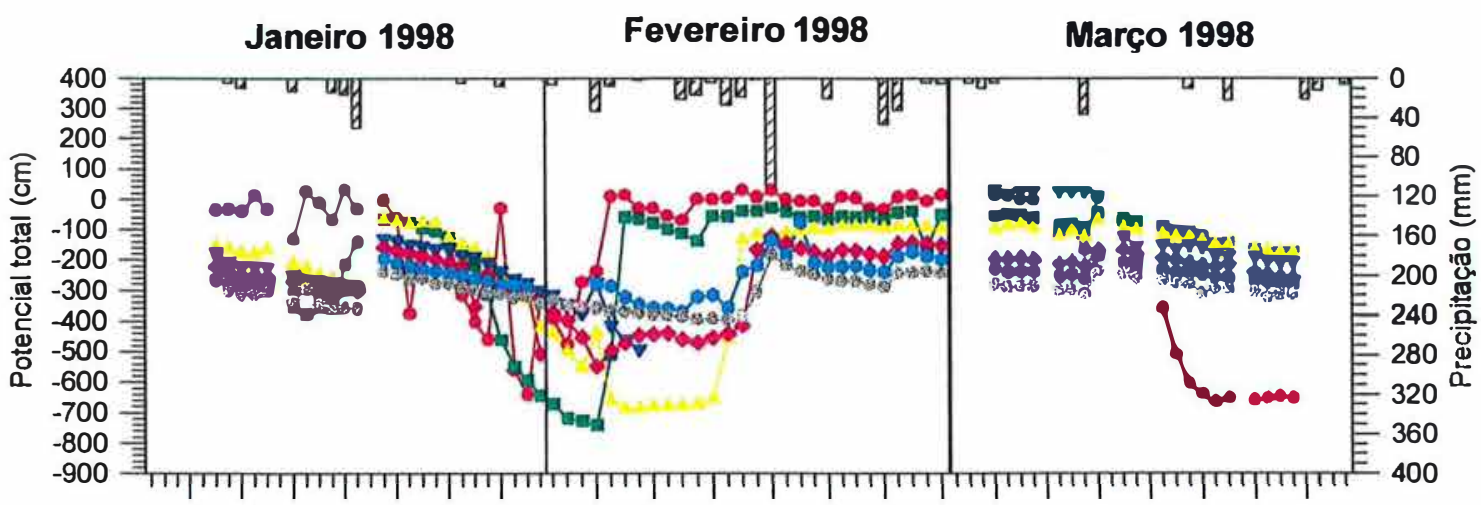

$\begin{array}{lllllllllllllllllllll}4 & 8 & 12 & 16 & 20 & 24 & 28 & 4 & 8 & 12 & 16 & 20 & 24 & 28 & 4 & 8 & 12 & 16 & 20 & 24 & 28\end{array}$

Data

Data

Data

\begin{tabular}{|l|}
\hline \\
$-10 \mathrm{~cm}$ (A) \\
$-30 \mathrm{~cm}(\mathrm{BA})$ \\
$60 \mathrm{~cm}(\mathrm{Bt1})$ \\
$-80 \mathrm{~cm}(\mathrm{Bt1} / \mathrm{Bt2})$ \\
$-100 \mathrm{~cm}$ (Bt2) \\
$-120 \mathrm{~cm}$ (Bt2/Bw) \\
$-150 \mathrm{~cm}$ (Bw) \\
\hline
\end{tabular}

Figura 26: Variações do potencial total do solo entre outubro/97 e março/98 da estação 2. 
$\mathrm{Na}$ estação 2, diferentemente da estação 1, somente a partir do tensiômetro de 80 $\mathrm{cm}$ que o solo encontrava-se bem seco após o período sem chuvas, sendo os horizontes até $60 \mathrm{~cm}$ influenciados pelas primeiras chuvas. A reumectação do solo também ocorre de forma rápida após o início das chuvas (1 mês). Após o processo de reumectação os horizontes se estabilizam num patamar de potencial entre -50 e $-300 \mathrm{~cm}$ de coluna de água. Da mesma forma que na estação 1 o potencial total decresce em profundidade. As flutuações nesta estação, concernentes à transição Bt-Bw, são um pouco mais marcadas que as flutuações da estação 1 , principalmente depois da seca de quinze dias durante o mês de janeiro, onde os tensiômetros de 60,80 e $100 \mathrm{~cm}$ sofreram flutuações importantes. Após o mês de fevereiro, acompanhando o decréscimo das chuvas no mês de março, o solo vai se secando lenta e gradualmente.

Os dados tensiométricos da estação 3 estão apresentados na Figura 27. Esta está localizada no começo do ombro junto com a trincheira 2 (Figura 5). A sequência de profundidades dos tensiômetros representam os seguintes horizontes: A, BA, Bt1, Bt2, Bt2/Bw1, Bw1, e Bw2.

Como observado para as estações anteriormente analisadas, o solo da estação 3 também apresentava-se bem seco no fim da época sem chuvas. A medida que as primeiras chuvas começaram a cair as profundidades até $80 \mathrm{~cm}$ foram as que mais rápidamente responderam à reumectação. Esta reumectação para o conjunto dos horizontes também foi rápida ocorrendo durante o periodo de um mês até atingir um patamar com potenciais que variavam entre 0 e $-300 \mathrm{~cm}$ de coluna de água. Da mesma forma que os perfis anteriores os potenciais totais da água dos horizontes aumentaram em direção à superfície. As flutuações neste patamar devido a períodos curtos de seca, são menos marcadas que na estação anterior e equivalentes à estação 1 . A maior flutuação, como visto nas outras estações, ocorreu após um periodo de seca durante o mês de janeiro, a reumectação após este período provocou a saturação de 

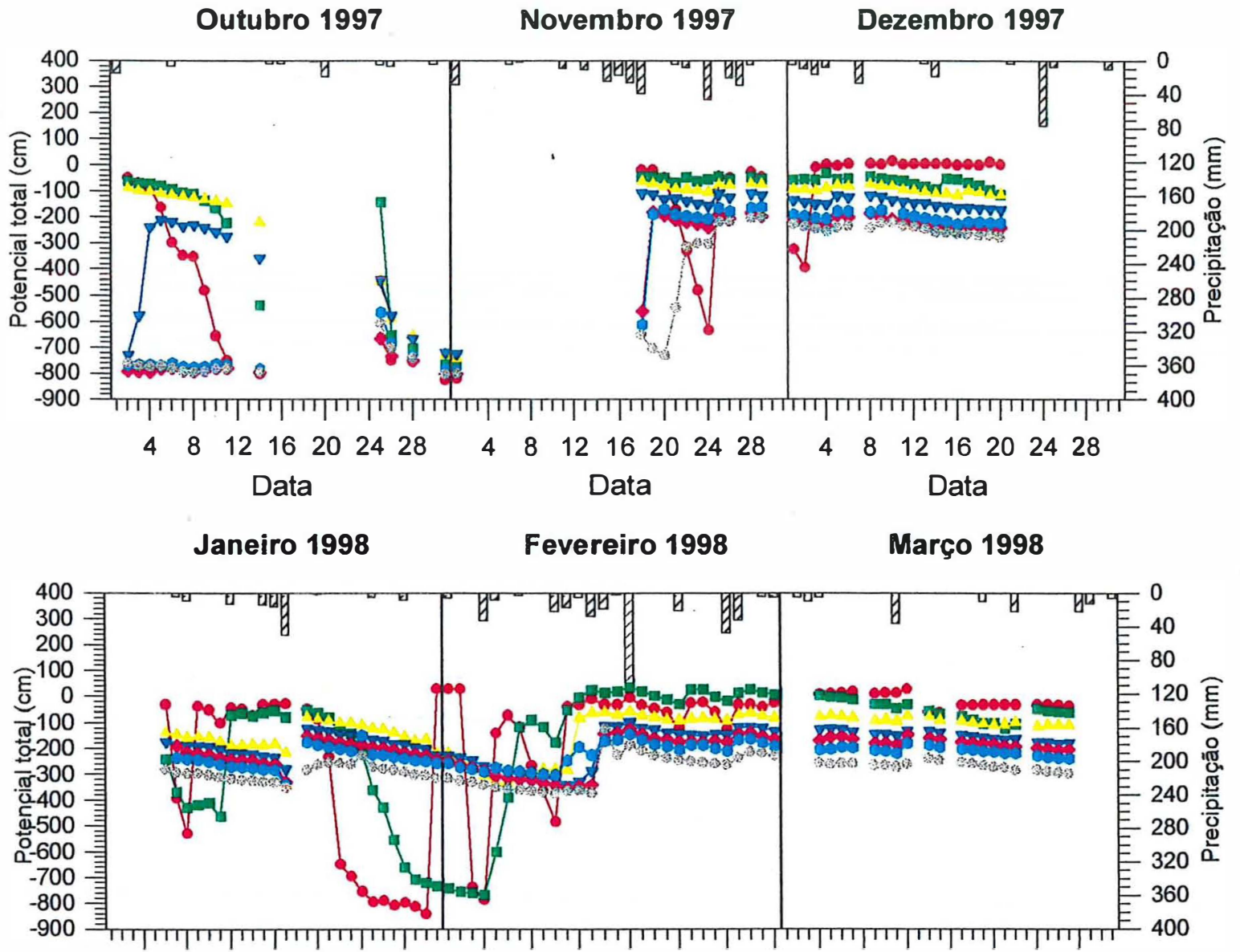

$\begin{array}{lllllllllllllllllllll}4 & 8 & 12 & 16 & 20 & 24 & 28 & 4 & 8 & 12 & 16 & 20 & 24 & 28 & 4 & 8 & 12 & 16 & 20 & 24 & 28\end{array}$

Data

Data

Data

Qta Chuva
$-10 \mathrm{~cm}(\mathrm{~A})$
$-30 \mathrm{~cm}$ (BA)
$-60 \mathrm{~cm}$ (Bt1)
$-80 \mathrm{~cm}$ (Bt2)
$-100 \mathrm{~cm}$ (Bt2/Bw1)
$-120 \mathrm{~cm}$ (Bw1)
$-150 \mathrm{~cm}$ (Bw2)

Figura 27: Variações do potencial total do solo entre outubro/97 e março/98 da estação 3. 

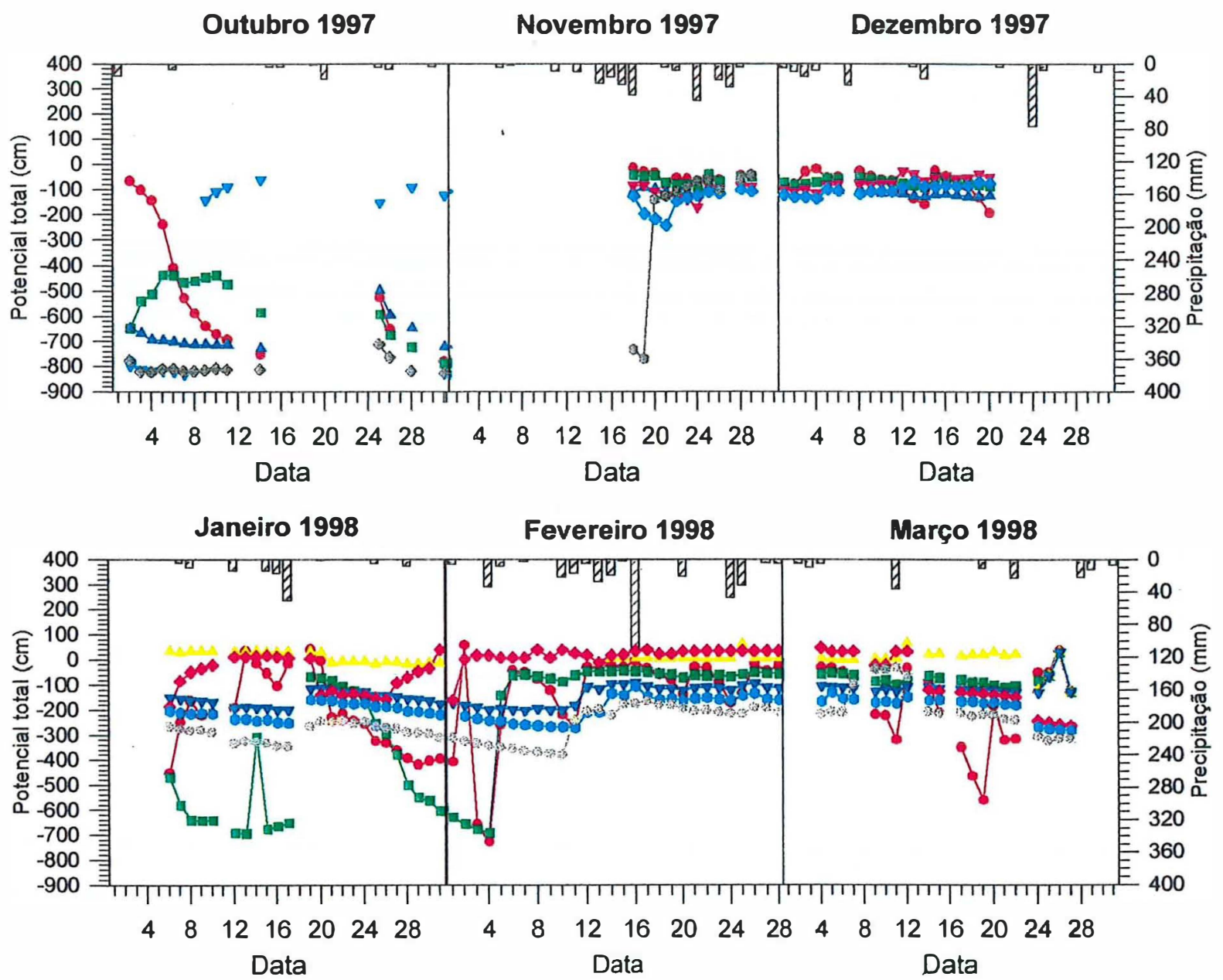

Figura 28: Variações do potencial total do solo entre outubro/97 e março/98 da estação 4. 
alguns horizontes, principalmente os superficiais. O mesmo fenômeno de secamento do solo lento e gradual observado nas outras duas estações também foi observado nesta.

A última estação tensiométrica esta localizada no ombro da vertente. Os dados de potencial desta estação estão apresentados na Figura 28. A sequência de profundidades dos tensiômetros representam os seguintes horizontes: $\mathrm{A}, \mathrm{Bt1}, \mathrm{Bt} 2 . \mathrm{Bt} 2$, $\mathrm{Bt} 2 / \mathrm{Bt} 3, \mathrm{Bt} 3$ e $\mathrm{Bt} 3 / \mathrm{BC}$.

O mesmo processo rápido de reumectação foi observado nesta estação tambem. Como nos casos anteriores a reumectação ocorreu rápidamente num espaço de tempo de um mês. Neste perfil somente o horizonte superficial umdeceu-se mais rápido, mas sofreu flutuações importantes até estabilizar ao entrar definitivamente na época chuvosa. O resto dos horizontes não sofreram esta flutuações rehumectando-se definitivamente uma vez que as chuvas já tinham começado. Os potenciais totais da água do solo se estabilizaram em dois patamares, um entre os meses de novembro e dezembro entre os potenciais de 0 a -100 e outro nos meses de janeiro, fevereiro e março entre os potenciais de 0 a -300. A seca que ocorreu durante o mês de janeiro provocou uma maior dispersão entre as curvas de potenciais totais da água dos horizontes, diminundo esta dispersão somente após as fortes chuvas de fevereiro. Este aumento de dispersão pelo secamento diferenciado dos horizontes provocou também maiores flutuações nos potenciais do solo. Observa-se que dois horizontes, o Bt2 $(60 \mathrm{~cm})$ e o Bt3 $(100 \mathrm{~cm})$ permaneceram saturados durante boa parte do tempo, principalmente após o começo das chuvas fortes de fevereiro. Isto poderia ser explicado utilizando as Figura 19 e 21, onde observa-se que além de apresentar as menores porosidades totais da sequência toda, eles apresentam as menores proporções de poros grandes, facilitando assim a sua rápida saturação. Repetindo o observado nas outras estações o solo sofre um secamento gradual e lento após o fim da estação de chuvas.

A análise global dos potenciais totais dos horizontes nas quatro estações identificam duas épocas bem distintas de umidade destes solos. A passagem de uma para outra ocorre de forma diferente dependendo do processo que esteja ocorrendo. Assim, o processo de reumectação foi rápido, atingindo valores de umidade altos que se mantém práticamente constantes durante toda a época chuvosa. O processo de secamento que foi 
gradual e lento durando vários meses. Estas evidências mostram que o período em que o solo permanece verdadeiramente seco durante o ano é muito curto, enquanto que o período onde o solo esta úmido é sujeito a flutuações da umidade é bastante prolongado. No período em que ocorre a mais significativa seca atmosférica (abril-setembro) não foram realizadas medições tensiométricas.

A medida que descemos na sequência, ou seja indo da estação 1 para a 4 , observa-se, nos períodos úmidos, valores de potencial. Sabendo que a chuva é a mesma em toda a área, esta variação do potencial pode ser explicada pela diminuição da porosidade neste mesmo sentido, como já visto anteriormente.

Os potenciais totais mais baixos apresentados na estações 2 e 3 em relação `a trincheira 1, nas profundidades entre 60 e $150 \mathrm{~cm}$, e a maior demora para o umedecimento destes horizontes após a seca do mês de janeiro e no começo das chuvas de fevereiro, mostra que além da componente vertical, bem evidente, do movimento da água na vertente, está ocorrendo um incipiente fluxo lateral não saturado de água entre as partes altas da sequência e as mais baixas, principalmente entre as estações 1 e 3 .

\subsubsection{Variações do potencial total do solo durante eventos chuvosos}

Apresentam-se as variações de potencial total observadas durante dois eventos chuvosos no mês de fevereiro. O primeiro corresponde a um evento onde o estado inicial do solo encontrava-se mais seco e o segundo onde o estado inicial do solo era mais úmido. As medidas foram realizadas a intervalos regulares, durante a chuva. de 15 minutos e após o fím da chuva em intervalos de 6 hs durante um período variável de 48 a $72 \mathrm{hs}$.

O primeiro evento ocorreu entre os dias 10 e 13/2/1998. Os dados são ilustrados na Figura 29 onde aparecem agrupados, por profundidades dos tensiômetros, as medições contínuas do potencial total de cada estação. 


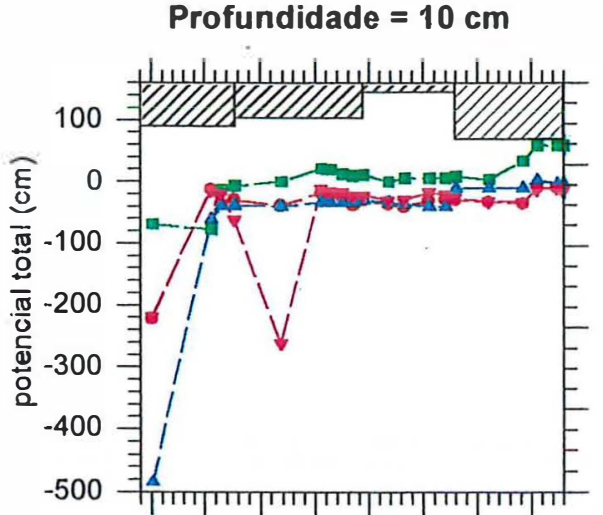

$\begin{array}{llllllll}0 & 10 & 20 & 30 & 40 & 50 & 60 & 70\end{array}$ tempo relativo $(\mathrm{h})$

Profundidade $=80 \mathrm{~cm}$

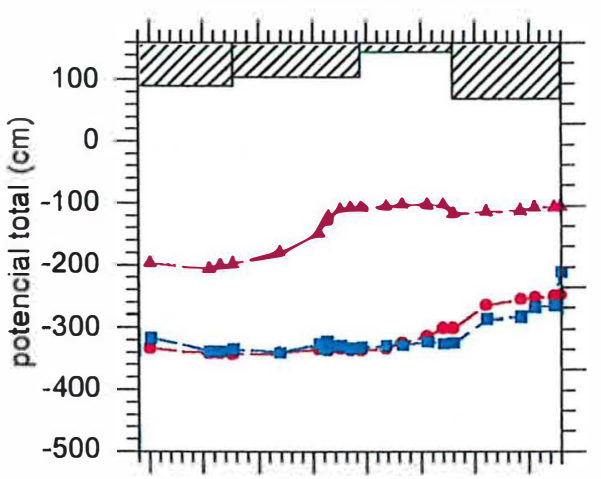

$\begin{array}{llllllll}0 & 10 & 20 & 30 & 40 & 50 & 60 & 70\end{array}$ tempo relativo $(\mathrm{h})$
Profundidade $=30 \mathrm{~cm}$

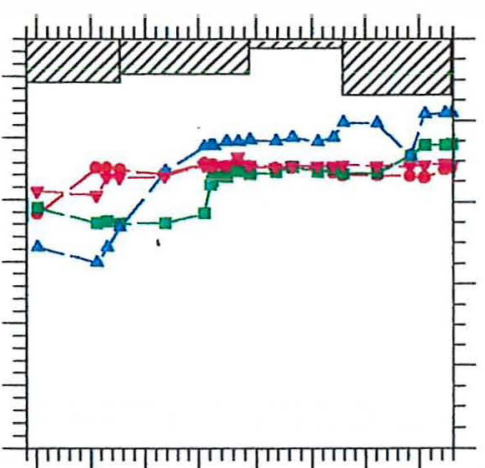

$\begin{array}{llllllll}0 & 10 & 20 & 30 & 40 & 50 & 60 & 70\end{array}$ tempo relativo $(\mathrm{h})$

\section{Profundidade $=100 \mathrm{~cm}$}

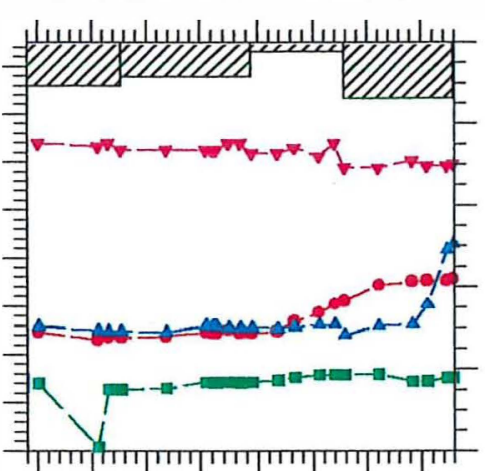

$\begin{array}{llllllll}0 & 10 & 20 & 30 & 40 & 50 & 60 & 70\end{array}$ tempo relativo $(\mathrm{h})$
Profundidade $=60 \mathrm{~cm}$

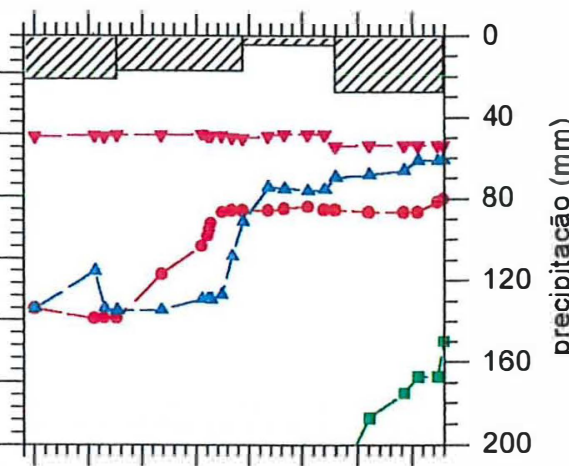

$\begin{array}{llllllll}0 & 10 & 20 & 30 & 40 & 50 & 60 & 70\end{array}$ tempo relativo $(\mathrm{h})$

\section{Profundidade $=120 \mathrm{~cm}$}

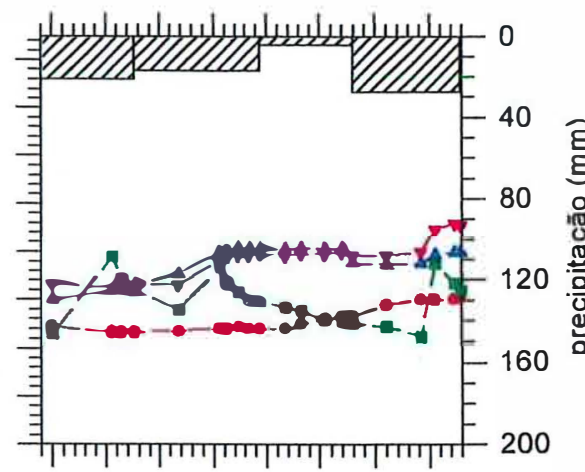

$\begin{array}{llllllll}0 & 10 & 20 & 30 & 40 & 50 & 60 & 70\end{array}$ tempo relativo $(\mathrm{h})$

Profundidade $=150 \mathrm{~cm}$
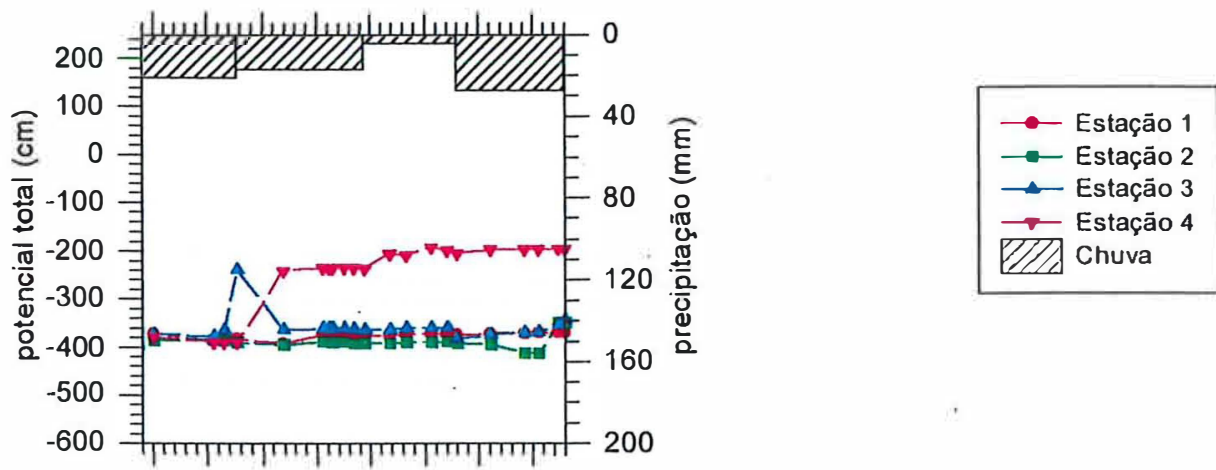

$\begin{array}{llllllll}0 & 10 & 20 & 30 & 40 & 50 & 60 & 70\end{array}$

tempo relativo $(\mathrm{h})$

Figura 29: Variações do potencial total do solo por profundidade durante o evento chuvoso entre 10- 13/2/98 
Observa-se nesta figura que quase todas (com exceção da Estação 4, profundidades de $60 \mathrm{a} 100 \mathrm{~cm}$ ) as curvas de potencial tendem a aumentar a medida que chove. Existem muito poucas diferenças entre as curvas das diferentes estações. Isto significaria que o movimento preferencial da chuva seria no sentido vertical. Existem algumas evidências concretas sobre um movimento lateral da água nesta escala de medições. Os valores baixos de potencial total na Estação 4 ate $100 \mathrm{~cm}$ e na profundidade de $100 \mathrm{~cm}$ entre as estações 1 e 2 mostram que poderia estar ocorrendo um movimento lateral devido às diferenças de potenciais positivas encontradas entre as estações.

Além do aporte lateral de água, um comportamento interessante é observado na estação 4. Nesta estação os valores dos potenciais nos horizontes superficiais até a profundidade de $100 \mathrm{~cm}$ apresentam-se muito altos perto da saturação, mas nas profundidades de 120 e $150 \mathrm{~cm}$ os valores de potenciais são semelhantes às outras estações. Comparando estes dados de potenciais com os de porosidade (Figura 19) observa-se que onde a porosidade é menor, ou seja nos horizontes superficiais, o potencial é mais alto, enquanto que nos horizontes aonde a porosidade e maior o potencial diminui. Desta forma demonstra-se que os horizontes superficiais devido à sua porosidade reduzida saturam-se facilmente durante os eventos chuvosos. Este processo de saturação não é exclusivo da estação 4, nas profundidades de 10 e $30 \mathrm{~cm}$ quase todas as estações permanecem saturadas ou quase saturadas durante a chuva.

O segundo evento chuvoso monitorado aconteceu entre os dias 24 e 26/2/1998, os dados referentes a este evento chuvoso estão ilustrados na Figura 30.

O estado inicial do solo antes deste evento era úmido, com isso observou-se variações menores no decorrer das medições em comparação com o evento monitorado entre os dias 10 e 13/2. As curvas de todas as profundidades das estações aparecem com formas semelhantes evidênciando um comportamento homogêneo quanto ao movimento da água para dentro do solo. Não foram evidênciados movimentos laterais da água resultando no movimento da água dentro destes solos estritamente vertical.

Devido ao seu estado hídrico inicial mais úmido. este evento chuvoso provocou a saturação dos horizontes superficiais destes solos, como evidênciado pelas curvas de 
Profundidade $=10 \mathrm{~cm} \quad$ Profundidade $=30 \mathrm{~cm} \quad$ Profundidade $=60 \mathrm{~cm}$
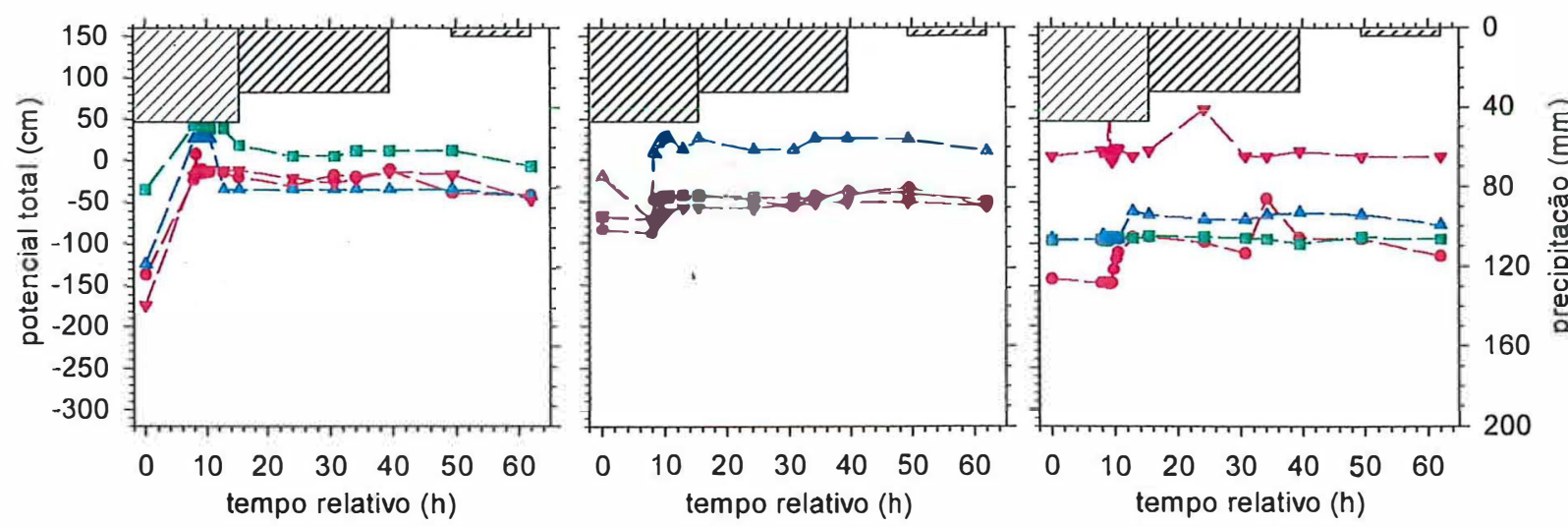

Profundidade $=80 \mathrm{~cm}$

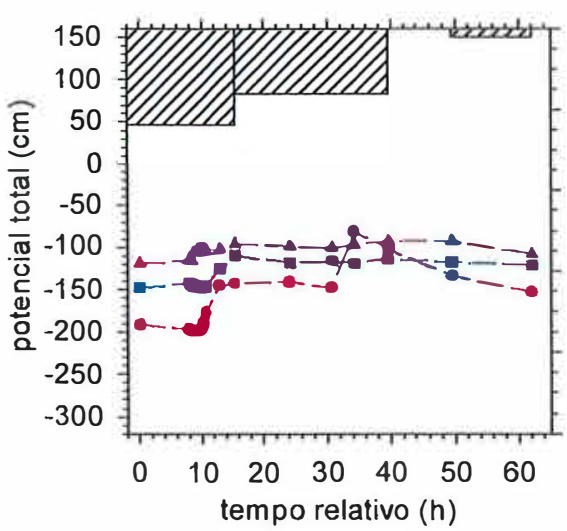

Profundidade $=100 \mathrm{~cm}$

Profundidade $=120 \mathrm{~cm}$
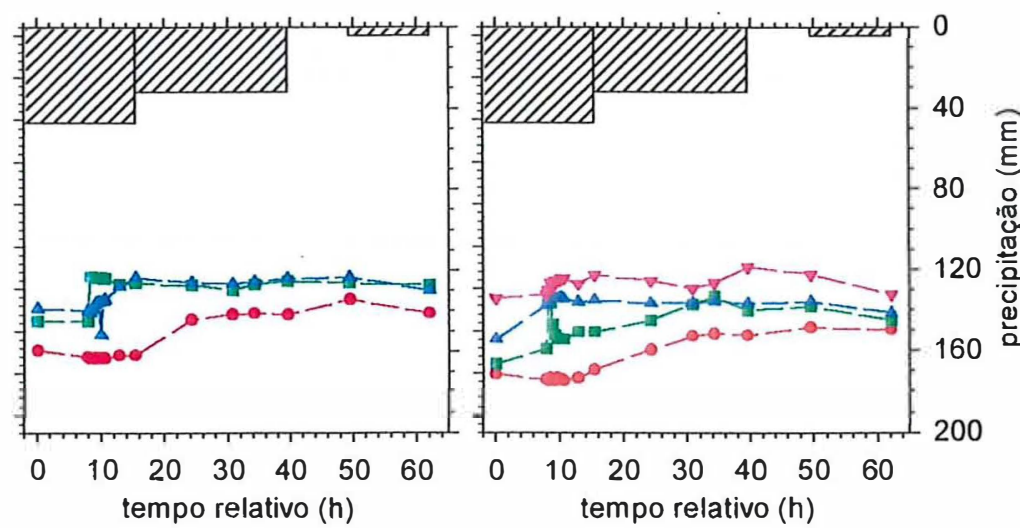

Profundidade $=150 \mathrm{~cm}$
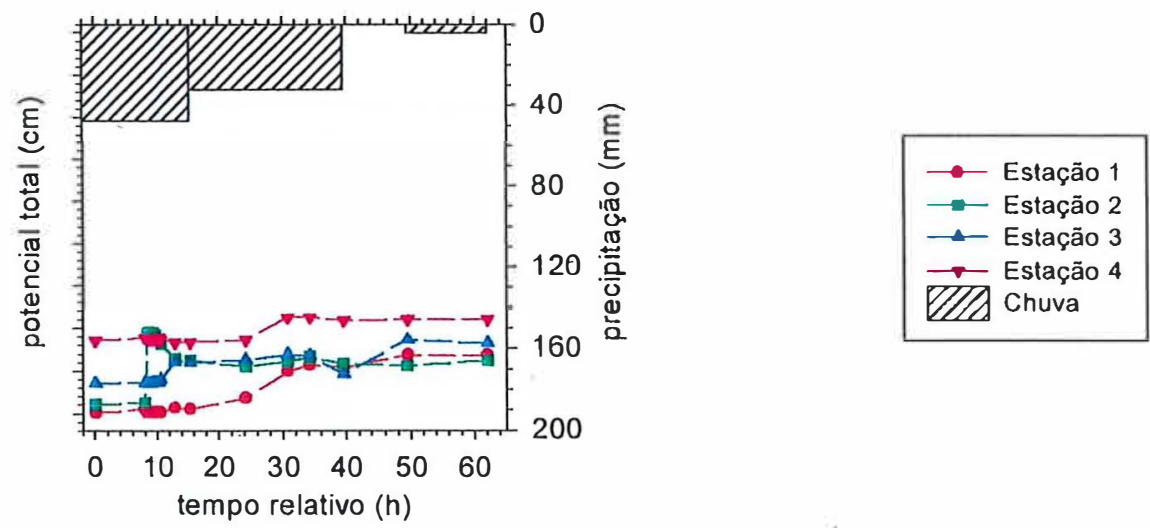

Figura 30: Variações do potencial total do solo por profundidade durante o evento chuvoso entre 24- 26/2/98. 
todas as estações à profundidade de $10 \mathrm{~cm}$ e a curva da estação 3 à profundidade de $30 \mathrm{~cm}$.

Um comportamento similar ao ocorrido durante o evento chuvoso de 10-13/2 foi observado com os dados da última estação, onde as camadas superficiais apresentavam potenciais menores em relação às camadas profundas devido à variação da porosidade deste perfil.

\subsection{Interpretações pedogenéticas}

\subsubsection{A organização dos horizontes e os processos pedogenéticos}

A organização da cobertura pedológica mostrou um adensamento vertical e ascendente do horizonte $\mathrm{Bw}$ para o $\mathrm{Bt}$ e também um adensamento lateral dentro dos diferentes horizontes da sequência. Nestes mesmos sentidos (vertical e lateral) ocorre uma diminuição e transformação da porosidade (de empilhamento para policôncava), uma reorganização das partículas de argila e uma maior aglomeração dos microagregados. Estas evidências apoiam a hipótese da coalescência de microagregados como a principal responsável deste adensamento.

O mecanismo que explicaria a ocorrência deste processo de adensamento pela coalescência de microagregados seriam as mudanças energéticas que ocorrem no solo devido aos ciclos alternados de umectação e dessecação. Este mecanismo foi também observado por Miklós (1992) trabalhando numa sequência de solos em Botucatu (SP) e por Pedro (1987) na África. Acredita-se que o processo de coalescência ocorreria durante a fase de reumectação, onde pela expansão do fundo matricial. os microagregados entrariam em contato uns com os outros formando pontos ou superfícies de contato. Além deste processo de expansão do fundo matricial, processos como a atividade biológica e/ou as pressões de confinamento que ocorrem dentro do solo podem provocar o contato entre os microagregados. A posterior passagem para um clima mais seco provocaria a cimentação práticamente definitiva destas superfícies de contato 
devido à contração do material e ao rearranjo das partículas de argila. Posteriormente novos ciclos de reumectação e dessecação solidificariam esta coalescência.

Esta mudança estrutural precisa de contrastes energéticos muito elevados. Segundo Pedro (1987), a coalescência de microagregados só ocorreria em situações onde o potencial do solo varia entre $\mathrm{pF} 0$ e 6 ao longo de um certo período de tempo. A dinâmica hídrica atual da vertente mostrou que as variações de $\mathrm{pF}$ máximas que ocorrem atualmente variam entre 0 e 3 , e que a permanência das condições energéticas extremas ocorrem por períodos curtos de tempo. Estas evidências mostram que atualmente não haveria energia suficiente para provocar uma coalescência estável dos microagregados, e consequentemente o adensamento. Assim a hipótese de que a coalescência ocorreria em condições mais secas que o atual estaria confirmada.

Foi mencionado anteriormente que ocorria um adensamento lateral, de montante para a jusante, dentro dos horizontes da sequência. Este adensamento lateral seria originado pelos mesmos mecanismos descritos anteriormente. $\mathrm{O}$ motor deste adensamento lateral seria o fluxo lateral de água que ocorre durante os períodos de chuva extrema, intensificando os processos de reumectação e dessecação. A dinâmica atual da água na vertente não mostrou evidências claras da existência de uma componente lateral da água no segmento da sequência onde ocorre a transição entre o Bt e o Bw. Desta forma, a presença de condições climáticas pretéritas mais secas. caracterizadas por chuvas isoladas e torrenciais, poderia ter provocado o aparecimento de fluxos laterais de água, intensificando o processo de adensamento pela coalescência de microagregados.

A formação de agregados e microagregados poliédricos, nos horizontes densos e microagregados, tem a sua origem nos processos de fissuração e microfissuração. Estas fissuras se formariam pela contração e expansão do fundo matricial devido a ciclos, mais curtos e frequentes, de umectação e dessecação. As evidências da dinâmica atual da água na vertente mostram que este processo de fissuração seria atual.

Foi constatado (Cooper, 1996) que a origem dos microagregados é complexa. Vários são os processos que intervém na formação deste tipo de agregados nos solos presentemente estudados Entre eles encontramos a atividade biológica (Eschenbrenner, 
1986; Miklós, 1992), o rearranjamento do plasma (Muller, 1977) e a geoquímica através de interações físico-químicas entre o ferro e a caulinita (Pedro et al., 1976; Chauvel et al., 1978; Cambier, 1986; Pedro, 1987; Santos et al., 1989). Um processo particularmente evidênciado nestes solos é a formação geoquímica dos microagregados a partir do material alterado de diabásio. Este processo partiria de um material grosseiro caulinitico e alterado do diabásio, com estrutura particular. Uma reorganização da estrutura, formando uma porosidade policôncava e mamelonar, e um adensamento deste material grosseiro pela cimentação por um material caulinítico tino rico em ferro, levariam a um processo de individualização de microagregados e aglomerados de microagregados. Paralelamente a estes processos, uma microfissuração do fundo matricial ajudaria na individualização dos microagregados. Nos segmentos da vertente onde a drenagem é vertical e a superfície mais plana, predominam os processos de formação de microagregados (subarredondados) como descrito acima. Em contrapartida, onde um componente lateral do movimento da água seria mais evidente (ombro), o processo de microagregação geoquímico é incipiente não conseguindo alcançar o completo desenvolvimento dos microagregados, e formando horizontes mais densos por processos de adensamento e preenchimento da porosidade por cutãs de iluviação.

A presença generalizada de cutãs de iluviação (ferriargilãs) distribuídos nos horizontes $\mathrm{Bt}$ e preenchendo a porosidade policôncava e mamelonar, sugere que este processo, apesar de ser considerado secundário e posterior à coalescência, também participa no adensamento destes horizontes. A constatação de períodos curtos de saturação nos horizontes densos superficiais da sequência, como consequência da redução do espaço poral ocorrida durante a fase de adensamento, provocaria um hidromorfismo temporário que promoveria a remoção de ferro, evidenciada pela identificação de cutãs de difusão, neocutãs, quasicutãs e nódulos ferruginosos. e a desestabilização das ligações ferro-argila facilitando assim a mobilização da argila e do ferro (Lepsch et al., 1977b; Queiroz Neto et al.,1981; Vidal Torrado. 1994).

A atividade biológica em toda a sequência é grande. Já se discutiu o seu papel na formação de microagregados. Uma outra ação da fauna do solo e identificada nos estudos realizados, é o de provocar o adensamento mecânico dos microagregados no 
momento da construção dos canais e cavidades. Ficou evidênciado que na maioria dos pedotúbulos as paredes encontravam-se adensadas. Considerando a ação da fauna no adensamento mecânico do solo verifica-se que este processo não é negligenciável. 


\section{CONCLUSÕES}

1) A morfologia e a dinâmica físico-hídrica da transição entre os horizontes com estrutura microagregada e os horizontes com estrutura macroagregada poliédrica, mostrou que a transformação estrutural entre estes materiais ocorre por um processo de adensamento pela coalescência dos microagregados.

2) O processo de coalescência dos microagregados ocorre pela alternância de ciclos de umedecimento e secamento do solo. O contato inicial entre os microagregados aconteceria durante a fase de reumectação sendo consolidada esta união durante a fase de secamento.

3) Contrastes energéticos mais fortes que os atuais seriam necessários para a estabilidade da estrutura resultante da coalescência dos microagregados. Somente um clima mais seco que o atual pode provocar o aparecimento de tais contrastes.

4) O aparecimento de fluxos laterais de água intensificaria os processos de adensamento pela coalescência dos microagregados no sentido lateral. A presença destes fluxos não parece ser atual, podendo ter o corrido durante condições climáticas pretéritas mais secas, caracterizadas por chuvas isoladas e torrenciais.

5) A formação de agregados e microagregados poliédricos é um processo mais atual, que ocorre devido aos processos de fissuração resultantes das contrações e expansões mais freqüentes do solo durante o clima úmido atual.

6) Outros processos de adensamento, como a ação mecânica da atividade biológica e o preenchimento da porosidade por cutãs de iluviação, foram identificados.

7) Os cutãs de iluviação (ferriargilãs) teriam a sua origem nos processos de hidromorfia temporária que ocorrem nos horizontes superficiais dos solos, provocando 
a desestabilização das ligações ferro-argila facilitando assim a mobilização e redistribuição do ferro e da argila.

8) A origem complexa dos microagregados. pela participação de mais de um processo na sua formação, foi determinada. Três processos foram identificados: um processo biológico, um processo físico-químico e um processo físico por fissuração.

9) A formação de microagregados físico-químicos estaria ligado a uma reorganização e a um adensamento da estrutura particular caulinítica encontrada na alterita do diabásio. O adensamento ocorreria pela cimentação das partículas grosseiras de caulinita por um material caulinítico fino rico em ferro. 


\section{REFERÊNCIAS BIBLIOGRÁFICAS}

ANDERSON, J.L. \& BOUMA, J., Relationships between saturated hydraulic conductivity and morphometric data of an argillic horizon. Soil Science Society of America. Journal., v .37, p.408-413, 1973.

ANDRIEUX, P.; CABIDOCHE, Y.M.; JAILLARD, B.; LUCAS, Y.\& BOULET, R... Dynamique de l'eau dans un système de sols à forte différenciation latérale (Plaine côtière ancienne, Guyane française). Science du Sol, v. 24,n.3, p. 285-299, 1986

ANKENY, M.D.; AHMED, M.; KASPAR, T.C.\& HORTON, R. Simple field method for determining unsaturated hydraulic conductivity. Soil Science Society of America. Journal., v.55, p. 467-470, 1991.

BEADOU, A. Expression micromorphologique de la microagrégation et de l'illuviation dans certains sols ferralitiques centraficans et dans les sols hydromorphes associés. Cahiers ORSTOM, Séries Pédologie, v.10, n.4, p.357-371, 1972.

BEADOU, A.; CHATELIN, Y.; COLlinET, J. \& SALA, G.H. Notes sur la micromorphologie de certains sols ferralitiques jaunes de régions équatoriels d'Afrique. Cahiers ORSTOM, Séries Pédologie, v.4, p.357-379, 1977. 
BEADOU, A.; FROMAGET, M. \& GUICHARD,E. Analyse des organisations micro et macrostructurales de certains sols ferralitiques centrafricains issus de roches basiques. In: FEDOROFF, N. \&. BRESSON, L.M (Ed.) ACTES DE LA VII RÉUNION INTERNATIONALE DE MICROMORPHOLOGIE DES SOLS. Paris, 1987, p.119124.

BEAUVAIS, A. \& TARDY, Y. Formation et dégradation des cuirasses ferrugineuses sous climat tropical humide, à la lisiére de la forêt équatoriale. C.R. Academie Science Paris, v.313, n. II, p.1539-1545, 1991.

BÉNARD, Y. Les techniques de fabrication des lames minces de sol. Cahiers Techniques INRA, v.37, p. 29-42, 1996.

BIRKELAND, P.W. Soils and Geomorphology. Oxford University Press, New York, 1984. 372p.

BOCQUIER G. Genèse et évolution de deux toposéquences de sols tropicaux du Tchad. Interprétation biogéodynamique, 1971, 350 p.Thèse, Univ. Strasbourg et Mémoires ORSTOM nº62, Paris.

BOULET, R. Toposéquences de sols tropicaux en Haute-Volta. Equilibre et déséquilibre pédobioclimatique. , 1974, 272 p. Thèse Sci., Univ. Strasbourg et Mémoires ORSTOM n 85 , Paris.

BOUlET, R.; CHAUVEL, A.; HUMBEL, F.X. \& LUCAS, Y. Analyse structurale et cartographie en pédologie : I - Prise en compte de l'organisation bidimensionnelle de la couverture pédologique : les études de toposéquences et leurs principaux apports à 
la connaissance des sols. Cahiers ORSTOM Séries Pédologie., v. XIX, n.4 p. 309321.1982.

BOULET, R. Análise estrutural da cobertura pedológica e cartografia. In: XXI CONGRESSO BRASILEIRO DE CIÊNCIA DO SOLO, Campinas, julho 1987. A Responsabilidade Social da Ciência do Solo, Sociedade Brasileira de Ciência do Solo, Campinas. p.79-90. 1988.

BOUlET, R.; CHAUVEL, A.; HUMBEL, F.X. \& LUCAS, Y. Analyse structurale et cartographie em pédologie. Cahiers ORSTOM Séries Pédologie, v. XIX. n 4, p. 309-351. 1982.

BREWER, R. Fabric and Mineral Analysis of Soils. Robert E. Krieger Publishing Company. Huntington, New York, 1976. 482p.

BRINKMAN, R. Ferrolysis, a hydromorphic soil forming process. Geoderma, v.3, p.199-206. 1970.

BRUAND, A.; COUSIN, I.; NICOUllaud, B.; DUVAL, O. \& BÉGON, J.C. Backscattered electron scanning images of soil porosity for analysing soil compaction around roots. Soil Science Society of America. Journal., v.60, p. 895-901. 1996.

BULLOCK, P.; FEDOROFF, N.; JONGERIUS, A.; STOOPS, G. \& TURSINA.T. Handbook for soil thin section description. Waine Research, Albrington. UK, 1985. 152p.

BULLOCK, P. \& THOMPSON, M.L. Micromorphology of Alfisols. In: .. DOUGLAS. L.A \& THOMPSON, M.L (Ed.). SOIL MICROMORPHOLOGY AND SOIL CLASSIFICATION, Anaheim, 1985. Proceedings of a symposium sponsored by 
Divisions S-5 and S-9 of the Soil Science Society of America, Anaheim. ed, SSSA, Madison. p.17-47. 1985.

BUOL, S.W. \& ESWARAN, H. The micromorphology of oxisols. In: DELGADO. M. (Ed) Proceedings Vth International Workshop Meeting Soil Micromorphology, Granada,., vol. 1:325-347. 1978.

BUOL, S.W.; HOLE, F.D.; McCRAKEN, R.J. Soil genesis and classification. The Iowa State University Press, Ames. 1980. 404p.

CAMARGO, O.A. de, MONIZ, A.C., JORGE, J.A. \& VALADARES, J.M.A.S. Métodos de análise química, mineralógica e física de solos do Instituto Agronômico de Campinas. Campinas, Instituto Agronômico, 1986. 94p. (Boletim técnico 106).

CARVALHO, A.; CHAUVEL, A. \& GONÇALVES, N.M.M. Alteration of basalt and formation of kaolinic and gibbsitic material in the region of Ribeirão Preto (SP), Brazil. In: LATERISATION PROCESS. Proceedings II International Seminar on Laterization Processes, São Paulo. p. 477-489. 1982.

CASTRO, S.S. Impregnação de amostras de solos para confecção de lâminas delgadas. Boletim Informativo da Sociedade Brasileira de Ciência do Solo, v.10, n. 2. p.44, 1985.

CASTRO, S.S. Sistemas de transformação pedológica em Marília, SP: B latossólicos e B texturais. São Paulo, 1989. 274p. Tese (Doutorado) Faculdade de Filosofia. Letras e Ciências Humanas da Universidade de São Paulo.

CHAUVEL, A. Recherches sur la transformation des sols ferralitiques dans la zone tropicale à saisons contrastées. Travails et Documents ORSTOM, v.62, 532p., 1977. 
CHAUVEL, A. \& PEDRO, G. Sur l'importance de l'extreme dessication (ultradessication) dans lévolution pédologique des zones tropicales à saisons contrastées. Cahiers de Recherche de la Academie de Sciences, v.286, p. 15811584. 1978.

CHAUVEL, G; BOCQUIER, G. \& PEDRO, G. La stabilité et la transformation de la microstructure des sols rouges ferralitiques de Casamance (Senegal). Analyse microscopique et données experimentales. In: SOIL MICROMORPHOLOGY PROCEEDINGS. $5^{\text {th }}$ INTERNATIONAL WORKSHOP MEETING ON SOIL MICROMORPHOLOGY, Universidad de Granada (Espanha). p. 779-813. 1978.

COLLEUILLE H., 1993. Approches physique et morphologique de la dynamique structurale des sols. Application à l'étude de deux séquences pédologiques tropicales. 1994, 354. Thèse Doct., Univ. Paris VI e ORSTOM Editions.

COMISSÃO DE SOLOS Levantamento de reconhecimento dos solos do Estado de São Paulo. Serv. Nac. de Pesq. Agronômica, Comissão de Solos, Ministério da Agricultura, CNEPA. 1960. (Boletim 12).

COOPER, M. Estratigrafia e pedogênese de uma de solos com B latossólico e B textural em Piracicaba (SP). Piracicaba, 1996. 140p. Dissertação (M.S.) - Escola Superior de Agricultura "Luiz de Queiroz", Universidade de São Paulo.

COSTER M. \& CHERMANT J.L., Précis d'analyse d'images. Presse du CNRS. Paris, 560 p. 1989. 
COUSIN I. Reconstruction 3D par coupes sériées et transport de gaz dans un milieu poreux. Application à l'étude d'un sol argilo-limoneux,. 1996,254 p. Thèse Doct., Univ. d'Orléans,.

CREUTZBERG, D. \& SOMBROEK, W.G. Micromorphological characteristics of Nitosols. ACTES DE LA VII RÉUNION INTERNATIONALE DE MICROMORPHOLOGIE DES SOLS, Paris.. p. 151-155. 1987.

CURI, N. \& FRANZMEIER, D.P. Toposequence of oxisols from the central plateau of Brazil. Soil Science Society America Journal v. 43, p. 341-346. 1984.

DEMATTÊ, J.L.I. Zircônio e Titânio da fração areia de solos. Revista Brasileira de Ciência do Solo, v.2, p.74-77. 1978.

DEXTER, A.R. Advances in characterization of soil structure. Soil \& Tillage Research, v.11, p.199-238. 1988.

DIJKERMAN, J.C. \& MIEDEMA, R. An Ustult-Tropept catena in Sierra Leone. West Africa, I. Characteristics, genesis and classification. Geoderma, v.42, p.1-27. 1988.

DREES, L.R. \& WILDING, L.P. Elemental variability within a sampling unit. Soil. Science Society of America Proceedings, v.37, p.82-87. 1973.

DULLIEN, F.A.L. Characterization of porous media. Pore level. Transport in Porous Media, v.6, p. 581-606. 1991.

EDWARDS, W.M.; NORTON, L.D. \& REDMOND, C.E. Characterizing macropores that affect infiltration into nontilled soil. Soil Science Society of America Journal, v.52, p.483-487. 1988 
ESCHENBRENNER, V. Contribution des termites à la micro-agrégation des sols tropicaux. Cahiers ORSTOM, Séries Pédologie, v.XXII, n.4, p.397-408. 1986.

ESWARAN, H. \& SYS, C. Argillic horizon in LAC soils: formation and significance to classification. Pedologie, v.29, p.175-190. 1979.

FEDOROFF, N. \& ESWARAN, H. Micromorphology of ultisols. In:. DOUGLAS. L.A \& THOMPSON, M.L. SOIL MICROMORPHOLOGY AND SOIL CLASSIFICATION. Proceedings of a symposium sponsored by Divisions S-5 and S9 of the Soil Science Society of America, Anaheim. ed., SSSA, Madison. p.145-164. 1985.

FOX, W.E. \& TEAKLE, L.J.H. What is soil structure? Nature, v.198,p. 1329-1330. 1963.

GARDNER, W.R., Some steady-state solutions of the unsaturated moisture flow equation with application to evaporation from a water table. Soil Science., r.85, p. 228-232, 1958.

GRIMALDI, M. \& BOULET, R. Relation entre l'espace poral et le fonctionnement hydrodynamique d'une couverture pédologique sur socle de Guyane française. Cahiers. ORSTOM, séries. Pédologie., v.XXV, n.3, 263-275. 1989

GUEHL, J.M. Dynamique de l'eau dans le sol en forêt tropicale humide guyanaise. Influence de la couverture pédologique. Annals of Science and. Forestry..v. 41, p.195-236. 1984. 
HALL, G.F. Pedology and Geomorphology. In: Pedogenesis and soil taxonomy. I Concepts and interactions. Elsevier Science PuBoletim, New York, 1983 p.117140.

HALLAIRE, V. Description of microcrack orientation in a clayey soil using image analysis. In: RINGROSE-VOASE, A. J \&. HUMPHREYS, G. S (Eds), Soil Micromorphology: Studies in Management and Genesis. PROC. IX INT. WORKING MEETING ON SOIL MICROMORPHOLOGY, Townsville, Australia, July 1992. Development in Soil Science, 22, Elsevier, Amsterdam, The Netherlands, pp. 549557. 1994

HALLAIRE, V. \& COINTEPAS, J.P.,. Caractérisation de la macroporosité d'un sol de verger par analyse d'image. Agronomie, v.13,p. 155-164. 1993

HALlaire, V.; CURMI, P. \& WIDIATMAKA,. Morphologie de la porosité et circulations préférentielles en saturé. Cas des horizons d'un système pédologique armoricain. Etude et Gestion des Sols. v.4, n.2, p.115-126. 1997.

HONEYCUTT, C.W.; HEIL, R.D. \& COLE, C.V. Climatic and topographic of three Great Plains soils: I. Soil morphology. Soil Science Society of America Journal v.54, p.469-475. 1990.

HORGAN, G.W.,. Mathematical morphology for analysing soil structure from images. European Journal of Soil Science, v.49, p.161-173. 1998

IPT. Mapa geomorfológico do Estado de São Paulo. Escala 1:1.000.000. Divisão de Minas e Geologia Aplicada do Instituto de Pesquisas Tecnológicas do Estado de São Paulo. São Paulo, 1981 b. 
ISBELL, R.F. The argillic horizon concept and its application to the classification of tropical soils. In: PROCEEDINGS CONFERENCE ON CLASSIFICATION OF TROPICAL SOILS, Kuala LumpuRevista Malasyan Society of Soil Science.p. 150157. 1980.

JACKSON, M.L. Soil chemical analysis. Advanced course. Madison, Wisconsin. Publicado pelo autor 1969. 894p.

JIMENEZ RUEDA, J. \& DEMATTÊ, J.L.I. Solos originados de lamitos da formação Marilia (Grupo Bauru) da região de Monte Alto, SP. Revista Brasileira de Ciência do Solo, v.12, n.2, p.161-170. 1988.

JOHNSON, D.L. Biomantle evolution and the redistribution of earth materials and artifacts. Soil Science, v.149, n.2, p.84-102. 1990.

JOHNSON, P.R. \& BEAVERS, A.H. A mineralogical characterization of some loessderived soils in Illinois. Soil Science Society America Proceedings, v.23, p. 143146. 1959.

JONGERIUS, A.; SCHOONDERBEEK, D.; JAGER, A. \& KOWALINSKI. ST., Electro-optical soil porosity investigation by means of Quantimet-B equipment. Geoderma, v.7, p. 177-198. 1972.

KUBIENA, W.L. Micropedology. Collegiate Press Inc., Ames, Iowa. 1938.

LEMOS, R.C. DE \& SANTOS, R.D. DOS Manual de descrição e coleta de solo no campo. Campinas, SBCS/SNLCS, 46p.. 1984. 
LEPSCH, I.F. \& BUOL, S.W. Investigations in an Oxisol-Ultisol toposequence in São Paulo State, Brazil. Soil Science Society America Proceedings, v.38, p.491-496. 1975.

LEPSCH, I.F.; BUOL, S.W. \& DANIELS, R.. Soil landscape relationships in the occidental plateau of São Paulo, Brazil: II. Soil morphology, genesis and classification. Soil Science Society America Journal, v.41, p.109-115. 1977.

LETEY, J., 1991. The study of soil structure: science or art. Australian Journal of Soil Research, v.29, p. 699-707.

LICHTE, M. Stonelines as a definite cycle feature in southeast Brazil: A geomorphological and pedological case study. Pedologie, v.XL, p. 101-109. 1990.

LUCAS, Y.; BOULET, R. \& ANDRIEUX P. Un système pédologique aval en Guyane française. Organisation et fonctionnement hydrodynamique. Cahiers ORSTOM, séries. Pédologie., v.22, n.1,p. 3-16. 1986

LUZ, L.R.Q.P.; SANTOS, M.C.D. \& MERMUT, A.R. Pedogênese em uma topossequência do semi-arido de Pernambuco. Revista Brasileira de Ciência do Solo, v.18, p. 95-102, 1992.

MCBRATNEY, A.B.; MORAN, C.J.; STEWART, J.B.; CATTLE, S.R. \& KOPPI, A.J.,. Modifications to a method of rapid assessment of soil macropore structure by image analysis. Geoderma, v.53, p. 255-274. 1992 
MÉROT, Ph.,. Contribution à l'étude du rôle du sol dans le fonctionnement hydrologique de bassins versants. Volume 1: Synthèse des travaux. Mémoire d'Habilitation à Diriger des Recherches, Univ. de Rennes 1, 81 p. 1.993.

MIKLÓS, A.A. DE W. Biodynamique d'une coverture pédologique dans la région de Botucatú, Brésil. , 438p. 1992. Tese de Doutoramento. Université de Paris VI, France. Vols. I e II.

MIKLÓS, A.A. DE W. Funcionamento biodinâmico da paissagem. Ciência \& Ambiente, v.IV, n.6, p. 75-83. 1993.

MIKLÓS, A.A. DE W. Terra Roxa Estruturada: Organização de orígem holocênica. In: XXV CONGRESSO BRASILEIRO DE CIÊNCIA DO SOLO. Viçosa, julho 1995. Resumos expandidos, Sociedade Brasileira de Ciência do Solo. Campinas. p.15671570. 1995.

MOLICOVA, H.; GRIMALDI, M.; BONELL, M. \& HUBERT, P. Using Topmodel towards identifying and modelling the hydrological patterns within a headwater, humid, tropical catchment. Hydrological Processes, v.11, p.1169-1196. 1997.

MONIZ, A.C. \& BUOL, S.W. Formation of an Oxisol-Ultisol transition in São Paulo, Brazil: I - Double-water flow model of soil development. Soil Science Society of America Journal, v.46,p. 1228-33, 1982.

MONIZ, A.C.; BUOL, S.W. \& WEED. S.B. Formation of an Oxisol-Ultisol transition in São Paulo, Brazil: II. Lateral Dynamics of Chemical Weathering. Soil Science Society of America Journal, v.46.p. 1234-37, 1982. 
MORAN, C.J.; KOPPI, A.J.; MURPHY, B.W.\& MCBRATNEY A.BComparison of the macropore structure of a sandy loam surface soil horizon subjected to two tillage treatments. Soil Use and Management. v.4, p.96-102, 1988.

MULLER, J.P. Microestruturation des structichrons rouges ferralitiques, à l'amont des modelés convexes (Centre-Cameroun). Aspects morphologiques. Cahiers ORSTOM, Séries Ped., v. 15, n.3, p.239-258.1977.

MULLER, J.P. Sequence of vertical evolution in the microorganization of loose ferralitic materials in the Cameroons. In: SOIL MICROMORPHOLOGY. INTERNATIONAL WORKSHOP MEETING SOIL MICROMORPHOLOGY, Proceedings London. A.B. Academic Publishers., London, p. 1-10. 1981.

MURPHY, C.P.; BULLOCK, P.. \& TURNER, R.H., The measurement and characterisation of voids in soil thin sections by image analysis. Part I. Principles and techniques. Journal of Soil Science, v.28, p. 498-508. 1977a.

MURPHY, C.P.; BULLOCK, P. \& BISWELL, K.J., The measurement and characterisation of voids in soil thin sections by image analysis. Part II. Applications. Journal of Soil Science, v.28, p. 509-518. 1977b.

NAHON, D. Cuirasses ferrugineuses et encroûtements calcaires au Sénégal occidental et en Mauritanie. Systèmes évolutifs, géochimie, structures, relais et coexistence. 232 p. 1976. Thèse Sci., Univ. Marseille et Mém. Sci. Géol., Strasbourg, nº 44.

NETTLETON, W.D.; FLACH, K.W. \& BRASHER. B.R. Argillic horizons without clay skins. Soil Science Society America Proceedings v.33 ,p.121-125. 1969. 
OLIVEIRA, J.B.DE; ALFONSI, R.R. \& PEDRO JUNIOR, M.J. Regimes hídricos e térmicos dos solos do Estado de São Paulo. In: CONGRESSO BRASILEIRO DE CIÊNCIA DO SOLO, $15^{\circ}$, Campinas, Sociedade Brasileira de Ciência do Solo, Anais. 1976. p.359-362.

PAGLIAI, M.; LA MARCA, M.; LUCAMANTE, G. \& GENOVESE L. Effects of zero and conventional tillage on the lengh and irregularity of elongated pores in a clay loam soil under viticulture. Soil Tillage Research..v. 4, p. 433-444. 1984.

PEDRO, G.; CHAUVEL, A. \& MELFI, A. Recherces sur la constitution des Terra Roxa Estruturada du Brésil. Annalles Agronomie, v. 27, n.3, p.265-294. 1976.

PEDRO, G. Géochimie, mineralogie et organisation des sols. Aspects coordonnés des problèmes pédogénétiques. Cahiers Orstom, Série Pédologie, v.23, n.3, p.169-186. 1987.

PENTEADO, M.M. Geomorfologia do Setor Centro Ocidental da Depressão Periférica Paulista. Tese de Doutoramento. FFCL de Rio Claro, 1968. Universidade de São Paulo, Instituto de Geografia. São Paulo. Série Teses e Monografias, N 22. 1976. $86 \mathrm{p}$.

PERECIN, D. \& CAMPOS, D.A.F. Evidências micromorfológicas de gênese de solos de Piracicaba. In: XV CONGRESSO BRASILEIRO DE CIÊNCIA SOLO, Campinas. 1975. Anais, p. 461-466. 1976.

PHILIP, J.R. Reply to "Comments on steady infiltration from spherical cavities". Soil Science Society of America Journal v.49, p.788-789. 1985. 
PIERSON, F.B. \& MULLA, D.J. Aggregate stability in the Palouse region of Washington: Effect of landscape position. Soil Science Society America Journal v.54, p.1407-1412. 1990.

QUEIROZ NETO, J.P.; CASTRO, S.S.; FERNANDES BARROS, O.N.; MANFREDINI, S.; RUELLAN, A. \& TOLEDO, G.S. Um estudo de dinâmica de solos: formação e transformação de perfis com horizonte $B$ textural. In: CONGRESSO BRASILEIRO DE CIÊNCIA DO SOLO, Salvador, 1980. Campinas, Sociedade Brasileira de Ciência do Solo. Resumos. 1981.

RAIJ, B. Van; QUAGGIO, J.A.; CANTARELlA, H.; FERREIRA, M.E.;LOPES. A.S. \& BATAGLIA, O.A. Análise de solos para fins de fertilidade. Campinas, Fundação Cargill, 1987. 165p.

RANZANI, G.; FREIRE, O. \& KINJO, T. Carta de solos do município de Piracicaba. Piracicaba, Centro de Estudos de Solos. ESALQ/USP, Brasil. 85p.. 1966.

RINGROASE-VOASE, A.J. A scheme for the quantitative description of soil macrostructure by image analysis. Journal of Soil Science., v.38, p.343-356. 1987

RINGROSE-VOASE, A.J. One-dimensional image analysis of soil structure. I. Principles. Journal of Soil Science. v.41, p. 499-512. 1990

RINGROASE-VOASE, A.J.. Micromorphology of soil structure: Description, quantification, application. Australia. Journal of Soil Research, v.29, p. 777-813. 1991. 
RINGROSE-VOASE, A.J. \& BULLOCK, P. The automatic recognition and measurement of soil pore types by image analysis and computer programs. Journal of Soil Science, v. 35, p. 673-684. 1984.

RINGROSE-VOASE, A.J. \& NORTCLIFF, S. The application of stereology to the estimation of soil structural properties: A preview. In: FEDOROFF, N.;. BRESSON, L.M \& COURTY, M. (EDS), SOIL MICROMORPHOLOGY. PROC. VII WORKING MEETING ON SOIL MICROMORPHOLOGY, Paris, July 1985, AFES, France, pp. 81-88. 1987.

RINGROSE-VOASE, A.J. \& NYS, C.. One-dimensional image analysis of soil structure. II. Interpretation of parameters with respect to four forest soil profiles. Journal of. Soil Science, v.41, p. 513-527. 1990

RINGROSE-VOASE A.J. Measurement of soil macropore geometry by analysis of sections through impregnated soil. Plant and Soil, v. 183, p.27-47. 1996

RITSEMA, C.J., OOSTINDIE, K. \& STOLTE, J... Evaluation of vertical and lateral flow through agricultural loessial hillslopes using a two-dimensioal computer simulation model. Hydrological Processes, v.10, p. 1091-1105. 1996

ROBAIN, H. \& CURMI, P.,. Rôle de la structure pédologique sur le comportement hydrique du sol aux faibles pF. Cahiers de.Recherche de la. Academie de. Sciences Paris, v. 303, série II, n.6, p. 509-514. 1986. 
RUELLAN A.,. Contribution à la connaissance des sols des régions méditerranéennes : les sols à profil calcaire différencié des plaines de la Basse Moulouya (Maroc Oriental), 302 p. 1970. Thèse Sci., Univ. Strasbourg et Mém. ORSTOM n 54, Paris.

RUELLAN, A., DOSSO, M. \& FRITSCH, E.,. L'analyse structurale de la couverture pédologique. Science du Sol, v.27, n.4, p. 319-334. 1989.

RUELLAN, A. \& DOSSO, M.,. Regards sur le sol. Foucher, Paris, 192 p. 1993.

RUPRECHT, J.K. \& SCHOFIELD, N.J.. Seasonal soil water dynamics in the Jarrah forest, western Australia. I: Results from a hillslope transect with coarse-textured soil profiles. Hydrological Processes, v.4, p. 241-258. 1990a

RUPRECHT, J.K. \& SCHOFIELD, N.J.. Seasonal soil water dynamics in the Jarrah forest, western Australia. II: Results from a site with fine-textured soil profiles. Hydrological Processes, v.4, p.259-267. 1990b

SANTOS, M.C.D.; MERMUT, A.R. \& RIBEIRO. M.R. Submicroscopy of clay microaggregates in an oxisol from Pernambuco, Brazil. Soil Science Society America Journal, v. 53, p. 1895-1901. 1989.

SCHUH, W.M. \& CLINE, R.L.. Efect of soil properties on unsaturated hydraulic conductivity pore-interaction factors. Soil Science Society of America Journal., v. 54, p. 1509-1518. 1990 
SERRA, J.. Image analysis and mathematical morphology. Academic Press, London, 610 p. 1982

SIMONSON, R. Outline os a generalized theory of soil genesis. Soil Science Society Of America Proceedings, v. 23, p. 152-156. 1959.

SOMBROEK, W.G. Soils with Nitic attributes.In: XIX CONGRÉS DE L'ASSOCIATION INTERNATIONALE DE LA SCIENCE DU SOL. Tokyo . Japon. 1990.

SOMBROEK, W.G. \& SIDERIUS, W. Nitosols and their genesis. In:Second meeting of the Eastern African sub-committee for soil correlationand land evaluation. Addis Adeba. FAO, World Soil Resources Reports, v.47, p. 84-86. 1976.

SOMBROEK, W.G. \& SIDERIUS, W. Nitosols, a quest for significant diagnostic criteria. Annual Report, International Soil Museum, Wageningen. p.11-31. 1981.

STOOPS, G. Micromorphology of some characteristic soil of Lower Congo (Kinshasha). Pedologie, v. 18, n. 1, p.110-149. 1968.

STOOPS, G. Micromorphology of the oxic horizon. PROCEEDINGS VITH INTERNATIONAL WORKSHOP MEETING SOIL MICROMORPHOLOGY. London, A.B. Academic Publishers, Rothamsted, 2:419-440. 1983.

STOOPS, G. \& BUOL, S.W. Micromorphology of oxisols. In: SOIL MICROMORPHOLOGY AND SOIL CLASSIFICATION. Proceedings of a symposium sponsored by Divisions S-5 and S-9 of the Soil Science Society of America, Anaheim. SSSA, Madison. 1985. 105-119p. 
STOOPS, G. \& JONGERIUS, A. Proposal for a micromorphological classification in soil materials. I. A classification of the related distributions of coarse and fine particles. Geoderma, v. 13, p. 189=200. 1975

TAMARI, S.. Relations between pore-space and hydraulic properties in compacted beds of silty-loam aggregates. Soil Technology, v.7, p. 57-73. 1994

TRAPNELL, C.G. \& WEBSTER, R. Microaggregates in red earths and related soils in East and Central Africa, their classification and occurence. Journal of Soil Science, v.37, p.109-123. 1986.

VAUCLIN, M. \& CHOPART, J.-L.,. L'infiltrométrie multidisques pour la détermination in situ des caractéristiques hydrodynamiques de la surface d'un sol gravillonnaire de Côte-d'Ivoire. L'Agronomie Tropicale, v. 46, p. 259-271. 1992

VIDAL TORRADO, P. Relações solo $\mathrm{x}$ relevo em Mococa (SP); influência das carcterísticas topográficas e posição na vertente nos atributos do solo. Piracicaba, 1989, 205p. Dissertação de Mestrado. Escola Superior de Agricultura "Luiz de Queiroz", USP.

VIDAL TORRADO, P. Pedogênese e Morfogênese no Distrito de Tupi (Piracicaba-SP). Piracicaba, 1994. 205p. Tese de Doutoramento. Escola Superior de Agricultura "Luiz de Queiroz", USP.

VIDAL TORRADO, P.; MAZZA, J.A.; CASTRO, S.S. \& DEMATTÊ. J.L.I. Micromorfologia e gênese de um Podzólico Vermelho Amarelo desenvolvido de sedimentos da formação Itararé no distrito de Tupi (Piracicaba-SP). In: $23^{\circ}$ CONGRESSO BRASILEIRO DE CIÊNCIA DO SOLO. Porto Alegre, julho de 1991. Resumos. Sociedade Brasileira de Ciência do Solo, Campinas, p.275. 1991. 
VIDAL TORRADO, P. \& LEPSCH, I.F. Morfogênese de solos de uma topossequência com transição B latossólico x B textural sobre migmatitos em Mococa (SP). Revista Brasileira Ciência Solo. v. 17, n.1, p.109-119. 1993.

VIDAL TORRADO, P.; LEPSCH, I.F.; CASTRO, S.S.; COOPER, M. \& PESSOTTI, P.R.R. Pedogênese em uma catena com transição B latossólico - B textural sobre sedimentos pelíticos em Piracicaba, SP. In; XXV CONGRESSO BRASILEIRO DE CIÊNCIA DO SOLO. Viçosa, julho de 1995. Resumos expandidos, Sociedade Brasileira de Ciência do Solo, Campinas. p. 1503-1505. 1995.

WEIBEL, E.R.,. Stereological methods. Vol. 2. Theoritical foundations. Academic Press, London, UK, 1980

WOODING, R.A.,. Steady infiltration from a shallow circular pond. Water Resources Research, v.4, p. 1259-1273. 1968

ZIDA, M. Structure et functionnement hydrique d'un système pédologique armoricain (France). Rennes. 1998, 192p. Tese de Doutoramento. Ecole Nationale Superieure Agronomique de Rennes, Rennes - França. 
Apêndice

MICROMORFOLOGIA DOS PERFIS DA TOPOSSEQUÊNCIA ESTUDADA. 


\begin{tabular}{|c|c|c|c|c|}
\hline \multirow[b]{2}{*}{ Atributo } & \multicolumn{4}{|c|}{ Horizontes } \\
\hline & $\mathrm{Btl}(40-55 \mathrm{~cm})$ & $\mathrm{Bt2}(80-95 \mathrm{~cm})$ & $\begin{array}{l}\text { Transiçāo Bt2/Bw } \\
(110-125 \mathrm{~cm})\end{array}$ & $\begin{array}{l}\mathrm{Bw} \\
(140-155 \mathrm{~cm})\end{array}$ \\
\hline Geral & $\begin{array}{l}\text { Heterogènea. Três zonas: Zona A } \\
(25 \%) \text {. Zona B }(50 \%) \text { e Zona C } \\
(25 \%) \text {. Apresentam densidades } \\
\text { diferentes }\end{array}$ & $\begin{array}{l}\text { Duas zonas. Zona A densa }(30- \\
40 \%) \text {. Zona microagregada }(60 \text { - } \\
70 \%)\end{array}$ & $\begin{array}{l}\text { Duas zonas. Zona } A \text { mais densa } \\
(40 \%) \text {. Zona } B(60 \%) \\
\text { microagregada }\end{array}$ & $\begin{array}{l}\text { Uma unica zona apresentando } \\
\text { localmente zonas densas }(5 \%) \text {. }\end{array}$ \\
\hline $\begin{array}{l}\text { Micro- } \\
\text { estrutura }\end{array}$ & $\begin{array}{l}\text { A) Agregados poliedricos } \\
\text { subangulares (tam.. } 5-20 \mathrm{~mm} \text { ). } \\
\text { pedalidade forte a moderada. } \\
\text { B) Agregados poliédricos } \\
\text { subangulares e aglomerados de } \\
\text { microagregados ( } 200 \mathrm{~m} \text { - } \\
\text { 1.5mm) } \\
\text { C) Microagregados } \\
\text { subarredondados }(60 \%, 200- \\
800 \mathrm{~m} \text { ) e poliedricos }(40 \% .200 \text { - } \\
800 \mathrm{~m} \text { ). Alguns aglomerados de } \\
\text { microagregados e fissuras. }\end{array}$ & $\begin{array}{l}\text { A) Agregados poliedricos } \\
\text { subangulares }(800 \mathrm{~m}-8 \mathrm{~mm} \text { ). } \\
\text { B) Microagregados e aglomerados } \\
\text { de microagregados }(20-1000 \mathrm{~m})\end{array}$ & $\begin{array}{l}\text { A) Agregados poliedricos } \\
\text { subangulares }(800 \mathrm{~m}-8 \mathrm{~mm}) \\
\text { pedalidade moderada a fore. } \\
\text { B) Mficroagregados }(400-500 \mathrm{~m}) \\
\text { e aglomerados de } \\
\text { microagregados. pedalidade } \\
\text { moderada a forte. }\end{array}$ & $\begin{array}{l}\text { Microagregados }(50 \mathrm{~m} \text {. } \\
1,6 \mathrm{~mm}) \text {, poucos agregados } \\
\text { poliedricos }(2-3 \mathrm{~mm} \text { e } 2-3 \mathrm{~cm}) \mathrm{e} \\
\text { aglomerados de microagregados. }\end{array}$ \\
\hline Plasma & $\begin{array}{l}\text { A) Vermelho escuro, argila } \\
\text { mineralogica, e oxidos de ferro, } \\
\text { isotico } \\
\text { B) Vermelho escuro, argila } \\
\text { mineralogica, e oxidos de ferro. } \\
\text { isótico } \\
\text { C) Vernelho escuro, argila } \\
\text { mineralogica, e oxidos de ferro, } \\
\text { isotico }\end{array}$ & $\begin{array}{l}\text { A) Vermelho escuro, argila } \\
\text { mineralogica e oxidos de ferro, } \\
\text { isotico com tendéncia a vossepico } \\
\text { B) Vermelho escuro, argila } \\
\text { mineralogica e oxidos de ferro. } \\
\text { isótico }\end{array}$ & $\begin{array}{l}\text { A) Vermelino escuro, isotico. } \\
\text { B) Vermelho escuro, isótico }\end{array}$ & Vermelho escuro, isotica \\
\hline Esqueleto & $\begin{array}{l}\text { Quartzo subarredondado e mai } \\
\text { selecionado. ( } 30 \text { in a } 1 \mathrm{~mm} \text { ). }\end{array}$ & $\begin{array}{l}\text { Quartzo subarredondado e mal } \\
\text { selecionado. }\end{array}$ & $\begin{array}{l}\text { Quartzo subarredondado e } \\
\text { moderadamente selecionado. }\end{array}$ & $\begin{array}{l}\text { Quartzo subarredondado }(50) \mathrm{m} \\
-1.5 \mathrm{~mm})\end{array}$ \\
\hline Poros & $\begin{array}{l}\text { A) Interagregados: Porosidade } \\
\text { fissural dominante ( } 70 \% \text {, tam. } \\
20-300 \mathrm{~m}) \text {, cavidades biologicas } \\
(30 \% \text {, tam. 102.5mm) } \\
\text { lntragregados: Mamelonares } \\
(80 \%, \text { tam. } 50-500 \mathrm{~m}) \mathrm{e} \\
\text { microfissuras }(20 \% \text {, tam. } 10- \\
30 \mathrm{~m}) \\
\text { B) Interagregados: Porosidade } \\
\text { policôncava }(80 \%, 20 \mathrm{~m}-1 \mathrm{~mm}) \text {. } \\
\text { poros fissurais }(10 \%, 50-100 \mathrm{~m}) \\
\text { cavidades biologicas }(10 \%, \\
300 \mathrm{~m}-1.5 \mathrm{~mm}) \\
\text { Intragregados: Porosidade } \\
\text { mamelonar (10-20 m). } \\
\text { C) Porosidade de empilhamento } \\
\text { (dom.). presença de poros } \\
\text { Inamelonares e fissuras dentro } \\
\text { dos aglomerados de } \\
\text { microagregados. }\end{array}$ & $\begin{array}{l}\text { A) Porosidade mameionar } \\
\text { dominante com dois tamanhos } 20 \text {. } \\
50 \mathrm{~m} \text { e } 100 \mathrm{~m}-1 \mathrm{~mm} \text {. Poros } \\
\text { fissurais }(10 \%, 100 \mathrm{~m}-1.6 \mathrm{~mm}) \mathrm{e} \\
\text { cavidades biologicas }(30 \%, 200 \mathrm{~m} \\
4 \mathrm{~mm}) \text {. } \\
\text { B) Porosidade de empilhamento, } \\
\text { algumas microfissuras }(5.20 \mathrm{~m})\end{array}$ & $\begin{array}{l}\text { A) Porosidade policóncava } \\
\text { dominante }(20-400 \mathrm{~m}) \text {. } \\
\text { cavidades }(200 \mathrm{~m}-1 \mathrm{~mm}) \mathrm{e} \\
\text { microtissuras }(20-50 \mathrm{~m}) \\
\text { B) Porosidade de empilhamento } \\
\text { com microfissuras entre os } \\
\text { agregados e porosidade } \\
\text { policòncava }(100-400 \mathrm{~m})\end{array}$ & $\begin{array}{l}\text { Porosidade de empilhamento } \\
\text { dominante, presenç de canais e } \\
\text { cavidades biologicas ( } 400 \mathrm{~m} \text { - } \\
2.5 \mathrm{~mm}) \text {, porosidade mamelonar } \\
(50-200 \mathrm{~m}) \text { dentro dos } \\
\text { aglomerados de microagregados. }\end{array}$ \\
\hline Trama & $\begin{array}{l}\text { A) Porfirica } \\
\text { B) Porfirica aberta } \\
\text { C) Enaulica }\end{array}$ & $\begin{array}{l}\text { A) Porfirica } \\
\text { B) Enáulica }\end{array}$ & $\begin{array}{l}\text { A) Porfirica e portiro-enaulica } \\
\text { B) Portiro-enaulica }\end{array}$ & Enáulica fechada \\
\hline Feiçōes & $\begin{array}{l}\text {-Ferri-argiliàs de iluviação }\left(20^{\circ} \text {. }\right. \\
\text { da lâmina). Alguns cutàs com } \\
\text { orientação manchada. } \\
\text { - Cutãs de difusāo de ferro nas } \\
\text { bordas doa agregados nas zonas } \\
\text { mais densas. }\end{array}$ & $\begin{array}{l}\text {-Ferri-argilàs de ıluviaçảo }(40 \% \text { da } \\
\text { lâmina). Alguns cutãs com } \\
\text { orientaçào manchada. } \\
\text {-Presença de ferrãs. }\end{array}$ & $\begin{array}{l}\text { B) Presença de ortotubulos } \\
\text { (200 m-3mm) com limites } \\
\text { externos adensados. }\end{array}$ & $\begin{array}{l}\text { Ortotubulos preenchidos com } \\
\text { microagregados e com limite } \\
\text { externo adensado. }\end{array}$ \\
\hline
\end{tabular}

\section{Micromorfologia do Perfil 1. Classificação do solo: Terra Roxa Estruturada Latossólica,} eutrófico, A moderado, textura muito argilosa. 


\begin{tabular}{|c|c|c|c|c|c|}
\hline \multirow[b]{2}{*}{ Atribute } & \multicolumn{5}{|c|}{ Horizonte } \\
\hline & $\mathrm{Btl}(40-55 \mathrm{~cm})$ & $\begin{array}{l}\mathrm{B} 12 \\
(80-96 \mathrm{~cm})\end{array}$ & $\begin{array}{l}\text { Bwl } \\
(100-116 \mathrm{~cm})\end{array}$ & $\begin{array}{l}\text { Bw2 } \\
(140-155 \mathrm{~cm})\end{array}$ & $\begin{array}{l}\mathrm{Bw} 2 / \mathrm{BC} \\
(170-186 \mathrm{~cm})\end{array}$ \\
\hline Geral & $\begin{array}{l}\text { Duas zonas. Zona A mais } \\
\text { densa com uma porosidade } \\
\text { mamelonar intema menor e } \\
\text { Zona B menos densa com } \\
\text { poros mamelonares mais } \\
\text { abertos. }\end{array}$ & $\begin{array}{l}\text { Duas zonas. Zona A ( } 85 \%) \\
\text { apresenta-se menos densa. } \\
\text { Zona } \mathrm{B}(15 \%) \text { maior } \\
\text { densidade. }\end{array}$ & $\begin{array}{l}\text { Duas zonas. Zona A } \\
\text { pouco densa }(80 \%) \text {. Zona } \\
\text { B mais densa }(20 \%) \text {. }\end{array}$ & $\begin{array}{l}\text { Trèszonas, Zona A, mais } \\
\text { densa }(5 \%) \text {, Zona B } \\
\text { densidade intermediaria } \\
(30 \%) \text { e Zona C } \\
\text { microagregada }(65 \%)\end{array}$ & 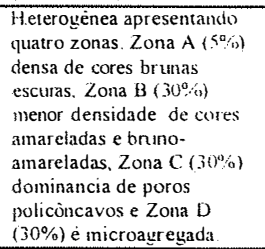 \\
\hline $\begin{array}{l}\text { Micro- } \\
\text { estrutura }\end{array}$ & $\begin{array}{l}\text { A) Agregados poliedricos } \\
\text { subangulares }(1-14 \mathrm{~mm}) \mathrm{e} \\
\text { microagregados }(50 \mathrm{~m} \text { - } \\
1,2 \mathrm{~mm}) \\
\text { B)Agregados poliedricos } \\
\text { subangulares }(2.6 \mathrm{~mm}) \\
\text { pedalidade moderada a } \\
\text { fraca. }\end{array}$ & $\begin{array}{l}\text { A) Agregados poliedricos } \\
\text { subangulares dominantes } \\
(300 \mathrm{~m}-1 \mathrm{~mm}) \mathrm{e} \\
\text { aglomerados de } \\
\text { microagregados. } \\
\text { Pedal idade moderada. } \\
\text { B) Agregados poliedricos } \\
\text { subangulares (2-3mm e } 5 \text { - } \\
\text { 8mm). Pedalidade } \\
\text { moderada. }\end{array}$ & $\begin{array}{l}\text { A) Aglomerados de } \\
\text { microagregados e } \\
\text { microagregados de formas } \\
\text { variadas ( } 100-800 \mathrm{~m} \text { ) } \\
\text { Pedalidade moderada. } \\
\text { B) Agregados poliedricos } \\
\text { subangulares ( } 2 \mathrm{~mm} \text { - } \\
\text { 2cm). Pedalidade fraca. }\end{array}$ & $\begin{array}{l}\text { A) Agregados poliedricos } \\
\text { subangulares ( } 8-14 \mathrm{~mm} \text { ) } \\
\text { Pedalidade torte } \\
\text { B) Agregados poliedricos } \\
\text { subangulares ( } 300 \mathrm{mI} \text { - } \\
4 \mathrm{~m} \text { ) e aglomerados de } \\
\text { microagregados. } \\
\text { Pedalidade moderada. } \\
\text { C) Microagregados de } \\
\text { forma variadas ( } 50 \mathrm{~m} \text { - } \\
\text { Imm) e aglomerados de } \\
\text { nicroagregados. } \\
\text { Pedalidade forte. }\end{array}$ & $\begin{array}{l}\text { A) Agregados poliedricos } \\
\text { subangulares Pedalidade } \\
\text { moderada. } \\
\text { B) Agregados poliedsicus } \\
\text { subangulares e } \\
\text { microagregados. } \\
\text { Pedalidade moderada. } \\
\text { C) Agreagdos poliedricos } \\
\text { subangulares e } \\
\text { aglomerados de } \\
\text { microagregados. } \\
\text { D) Microa gregados ( } 50 \mathrm{~m} \\
\text { - 1mm), aglomerados de } \\
\text { microagregados ( } 1-5 \mathrm{~mm}) \\
\text { Pedalidade forte. }\end{array}$ \\
\hline Plasma & $\begin{array}{l}\text { A) Vermelho escuro, argila } \\
\text { mineralogica. e oxidos de } \\
\text { ferro, isotico } \\
\text { B) Vermelho escuro, } \\
\text { argila mineralogica, e } \\
\text { oxidos de ferro, isotico }\end{array}$ & $\begin{array}{l}\text { A) Vermelho escuro, argila } \\
\text { mineralogica e oxidos de } \\
\text { ferro, isotico. } \\
\text { B) Vermelho escuro, argila } \\
\text { mineralógica e oxidos de } \\
\text { ferro, isótico. }\end{array}$ & $\begin{array}{l}\text { A) Vermelho escuro. } \\
\text { isotico } \\
\text { B) Vermelho escuro, } \\
\text { isotico }\end{array}$ & $\begin{array}{l}\text { Vermelho escuro.argila } \\
\text { mineralogica e oxidos de } \\
\text { ferro, isotico. }\end{array}$ & $\begin{array}{l}\text { A) Biuno escuro, isotico. } \\
\text { B) Amarelado e bruno- } \\
\text { amarelado. argilassepico. } \\
\text { C) Vermelho escuro, } \\
\text { isotico } \\
\text { D) Vermelho escuro, } \\
\text { isótico }\end{array}$ \\
\hline Esqueleto & $\begin{array}{l}\text { Quartzo subarredondado e } \\
\text { moderadamente } \\
\text { selecionado }(20 \mathrm{~m} \text { - } \\
1,5 \mathrm{~mm})\end{array}$ & $\begin{array}{l}\text { Quartzo subarredondado, } \\
\text { moderadamente } \\
\text { selecionado. }\end{array}$ & $\begin{array}{l}\text { Quartzo subarredondado e } \\
\text { quarzo metamorfico } \\
\text { (20 m-6mm). }\end{array}$ & $\begin{array}{l}\text { Quartzo subarredondado. } \\
\text { alguns irregulares e de } \\
\text { tipo fissurado. }\end{array}$ & $\begin{array}{l}\text { Predominio de quartzo } \\
\text { subarredondado e fissurado } \\
(20 \mathrm{~m}-1,5 \mathrm{~mm})\end{array}$ \\
\hline Poros & $\begin{array}{l}\text { A) Fissuras e microfissuras } \\
(60 \%) 20-300 \mathrm{~m}) \\
\text { cavidades e canais }(25 \%, 1 \text { - } \\
16 \mathrm{~mm}) \text {, poros de } \\
\text { empilhamento }(10 \%) \text { e } \\
\text { poros inamelonares }(5 \% \text {, } \\
20-300 \mathrm{~m}) \\
\text { B)Poros policoncavos } \\
(60 \%, 20-60 \mathrm{~m}) \text {, } \\
\text { cavidades e canais } \\
\text { biológicos }(20 \%, 400 \mathrm{~m} \text {. } \\
4 \mathrm{~mm}) \text { e fissuras }(20 \%, 20 \text {. } \\
200 \mathrm{~m}) \text {. }\end{array}$ & $\begin{array}{l}\text { A) Poros mamelonares } \\
\text { dominantes }(60 \%), 20 \mathrm{~m} \text { - } \\
1,5 \mathrm{~mm}), \text { cavidades }(15 \%) \text {. } \\
200 \mathrm{~m}-3 \mathrm{~mm} \text {, canais } \\
(15 \%), 5-8 \mathrm{~mm}) \text { e fissuras } \\
(10 \%) \text {. } \\
\text { B) Poros mameionares } \\
(40 \%, 20-400 \mathrm{~m}) \text { dentro } \\
\text { dos agregados. cavidades } \\
(30 \%, 500 \mathrm{~m}-5 \mathrm{~mm}) \\
\text { canais }(20 \%, 500 \mathrm{~m} \text { - } \\
1,5 \mathrm{~mm}) \text { e microf issuras } \\
(10 \%, 5-8 \mathrm{~mm})\end{array}$ & $\begin{array}{l}\text { A) Poros policóncavos } \\
\text { abertos }(60 \%, 50 \text { - } \\
800 \mathrm{~m}), \text { cavidades }(10 \% \text {. } \\
6.5-4 \mathrm{~mm}) \text {, canais }(10 \% \text {, } \\
1.5-10 \mathrm{~mm}) \mathrm{e} \\
\text { microfissuras }(10 \% \text {, } \\
20 \mathrm{~m}) \text {. } \\
\text { B)Poros mamelonares } \\
\text { dominantes }(20-400 \mathrm{~m}) \text {. } \\
\text { microt issura }(20 \mathrm{~m})\end{array}$ & 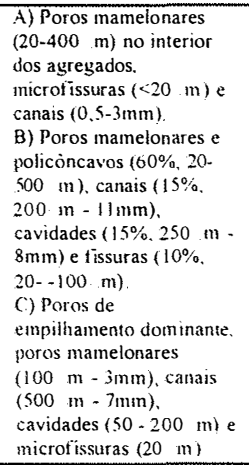 & 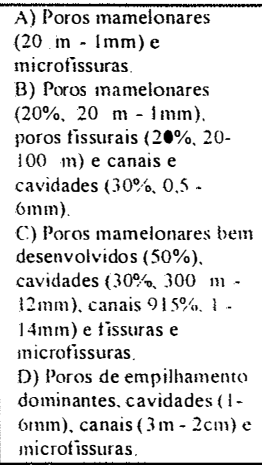 \\
\hline Trama & $\begin{array}{l}\text { A) Porfirica } \\
\text { B) Porfirica }\end{array}$ & $\begin{array}{l}\text { A) Porfiro-enaulica } \\
\text { B) Porfirica. }\end{array}$ & $\begin{array}{l}\text { A) Portiro-enaulica com } \\
\text { algumas areas enaulicas. } \\
\text { B) Porfirica }\end{array}$ & $\begin{array}{l}\text { A) Portirica fechada } \\
\text { B) Portiro-enaulica. } \\
\text { C) Enaulica }\end{array}$ & $\begin{array}{l}\text { A) Porfirica } \\
\text { B) Porfiro-enaulica } \\
\text { C) Porfiro-enaulica } \\
\text { D) Enáulica }\end{array}$ \\
\hline Feicōes & $\begin{array}{l}\text { Presença de ferriargilăs } \\
(20 \%, 30-500 \mathrm{~m}) \text { na } \\
\text { porosidade policòncava e } \\
\text { mamelonar e fissural e } \\
\text { cutãs de difusão. Formação } \\
\text { de neo-cutàs por } \\
\text { movimentaçào de ferro. } \\
\text { Presença de pápulas. }\end{array}$ & $\begin{array}{l}\text { Presença de ortotubulos } \\
\text { com limites externos } \\
\text { adensados e preenchidos de } \\
\text { microagregados. Presença } \\
\text { de ferriargilās de iluviação } \\
\text { e cutans de difusão }(20 \% \text {, } \\
20-250 \mathrm{~m}) \text {. }\end{array}$ & $\begin{array}{l}\text { Presença de ortotubulos } \\
(4-15 \mathrm{~mm}) \text { com as paredes } \\
\text { adensadas e preenchidos } \\
\text { com microagregados. }\end{array}$ & & Alta atividade biológica. \\
\hline
\end{tabular}

Micromorfologia do Perfil 2. Classificação do solo: Terra Roxa Estruturada Latossólica, eutrófico, A moderado, textura muito argilosa. 


\begin{tabular}{|c|c|c|c|c|c|}
\hline \multirow[b]{2}{*}{ Atributo } & \multicolumn{5}{|c|}{ Horizontes } \\
\hline & $\mathrm{Bt}(15-30 \mathrm{~cm})$ & $\mathrm{B} 12(50-65 \mathrm{~cm})$ & $\mathrm{Bt} 3(110-125 \mathrm{~cm})$ & Alteraçào $(192-202 \mathrm{~cm})$ & Alteração $(200)-215 \mathrm{~cm})$ \\
\hline Geral & $\begin{array}{l}\text { Duas zonas. Zona } A \\
\text { dominate de cor } \\
\text { verineiha escura, e Zona } \\
\text { B, de cor bruna } \\
\text { avermelhada }\end{array}$ & $\begin{array}{l}\text { Homogéneo e bastante } \\
\text { denso. }\end{array}$ & $\begin{array}{l}\text { Duas zonas. Zona } \mathrm{A},\left(50^{\circ} ;\right) \\
\text { densa. eZona } \mathrm{B}\left(50^{\circ} \%\right) \mathrm{com} \\
\text { poros mamelonares bem } \\
\text { desenvolvidos. }\end{array}$ & $\begin{array}{l}\text { Duas zonas. Zona } \mathrm{A} \text {. } \\
\text { zona de } \\
\text { alteraçãotormada por } \\
\text { um alteroplasma de cor } \\
\text { bnuna e bruna } \\
\text { amarelada. e Zona } \mathrm{B} \text {. } \\
\text { zona pedosenentica de } \\
\text { cor avermethada c } \\
\text { bnuna-avermelhada }\end{array}$ & $\begin{array}{l}\text { Três zonas. Zona } A(+0 \%) \\
\text { alteroplasma. Zona } B \\
\text { alterplasma mais vernetho, } \\
\text { e Zona C pedoplasma com } \\
\text { estnutura pedologica. }\end{array}$ \\
\hline $\begin{array}{l}\text { Micro- } \\
\text { estrutura }\end{array}$ & $\begin{array}{l}\text { A) Agregados } \\
\text { poliedricos subangulares } \\
(3 \mathrm{~mm}-2 \mathrm{~cm} \text { ). } \\
\text { Pedalidade moderada a } \\
\text { fraca. } \\
\text { B) Agregados } \\
\text { poliedricos subangulares } \\
\text { (2-6mm). Pedalidade } \\
\text { moderada. }\end{array}$ & $\begin{array}{l}\text { Agregados poliedricos } \\
\text { subangulares ( } 2.8 \mathrm{~mm} \text { ) } \\
\text { Pedalidade moderada. }\end{array}$ & $\begin{array}{l}\text { A) Agregados poliedricos } \\
\text { subangulares ( } 3-8 \mathrm{~mm} \text { ). } \\
\text { Pedalidade moderada. } \\
\text { B) Aglomerados de } \\
\text { microagregados }(200 \mathrm{~m} \text { - } \\
\text { / } \mathrm{mm} \text { ), agregados poliedricos } \\
\text { subangulares (1-3 } \mathrm{mm} \text { ) } \\
\text { Pedalidade moderada. }\end{array}$ & $\begin{array}{l}\text { A) Alteroplasma com } \\
\text { estrutura particular. } \\
\text { B) Agregados } \\
\text { poliedricos subangulares } \\
\text { (1-12mm) e } \\
\text { aglomerados de } \\
\text { microagregados } \\
\text { (200 } \mathrm{m}-2 \mathrm{~mm}) \text {. }\end{array}$ & 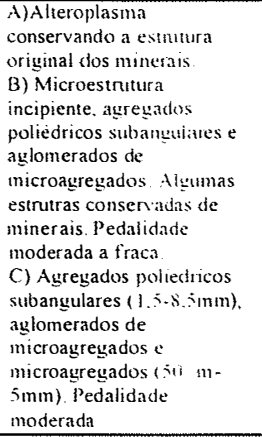 \\
\hline Plasma & $\begin{array}{l}\text { A) Vermelho escuro, } \\
\text { argila mineralogica. e } \\
\text { oxidos de ferro, isótico } \\
\text { B) Bruno avernethado. } \\
\text { isotico com tendecias a } \\
\text { vossépicas e } \\
\text { argilassepicas. }\end{array}$ & $\begin{array}{l}\text { Vermetho escuro, argila } \\
\text { mineralogica e oxidos de } \\
\text { ferro, isótico com tendència } \\
\text { a vossépica e argilassepica. }\end{array}$ & $\begin{array}{l}\text { A) Vermelho escuro, isotico } \\
\text { com dominios argilassepicos e } \\
\text { vossepicos, argila } \\
\text { mineralogica e oxidos de } \\
\text { ferro. } \\
\text { B) Vernelho escuro, sendo } \\
\text { bastante heterog6eneo } \\
\text { apresentando zonas vossepica. } \\
\text { argilassepicas e insepicas. }\end{array}$ & $\begin{array}{l}\text { A) Alteroplasma com } \\
\text { birref ringencia } \\
\text { argilassepica. } \\
\text { B) Argilassepica e } \\
\text { isotica em alguma areas } \\
\text { impregnadas com ferro }\end{array}$ & $\begin{array}{l}\text { A) Alteroplasma comn } \\
\text { birrefringència } \\
\text { argilassepica } \\
\text { B) Argilassepico e isotico } \\
\text { nas àreas com maior } \\
\text { concentração de ferro. } \\
\text { C) Isótica nas areas com } \\
\text { concentração de ferro e } \\
\text { argilassépica. }\end{array}$ \\
\hline Esqueleto & $\begin{array}{l}\text { Quartzo fissurado }(20- \\
500 \mathrm{~m}) \text {. } \\
\text { subarredondados e } \\
\text { poliedricos. }\end{array}$ & $\begin{array}{l}\text { Quartzo predominam os } \\
\text { subarredondado e alsguns } \\
\text { subangulares, mal } \\
\text { selecionado. }\end{array}$ & $\begin{array}{l}\text { Heterogeneo formado por } \\
\text { quartzo, minerais ferro- } \\
\text { magnesianos e plagioclasios } \\
\text { alterados. }\end{array}$ & $\begin{array}{l}\text { A) Plagioclasios } \\
\text { alterados }(50 \% \text {, minerais } \\
\text { ferro-magnesianos } \\
(30 \%) \text {, quartzo }(20 \%) \text {. } \\
\text { B) Quartzo }(60 \%), \\
\text { playiociasios }(30 \%) \text {. } \\
\text { minerais ferro- } \\
\text { magnesianos }(10 \%)\end{array}$ & 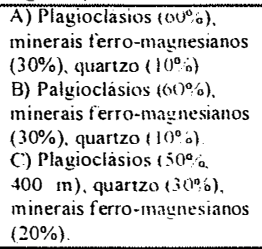 \\
\hline Poros & $\begin{array}{l}\text { A) Poros mamelonares } \\
(50 \%, 50-70 \mathrm{~m}), \\
\text { fissurais }(30 \%, 100 \mathrm{~m} \text { - } \\
5 \mathrm{~cm}) \text {, cavidades e canais } \\
\text { biologicos }(20 \%, 1 \text { - } \\
4 \mathrm{~mm}) \text {. } \\
\text { B) Poros fissurais } \\
(40 \%) \text {. mamelonases } \\
(30 \%) \text { e cavidades } \\
\text { biologicas }(30 \% \text {. } \\
500 \mathrm{~m}-5 \mathrm{~mm})\end{array}$ & $\begin{array}{l}\text { Poros mamelonares }(40 \% \\
5 \mathrm{~m}-3 \mathrm{~mm}) \text {, cavidades e } \\
\text { canais biologicos }(30 \% \\
500 \mathrm{~m}-7 \mathrm{~mm}) \text {, fissuras } \\
(30 \% .0 .5-5 \mathrm{~cm})\end{array}$ & $\begin{array}{l}\text { A) Poros mamelonares }\left(50^{\circ} \%\right. \\
50-800 \mathrm{~m}) \text {, fissurais }(30 \% \text {. } \\
100 \mathrm{~m}-4 \mathrm{~mm}) \text {, canais } \mathrm{e} \\
\text { cavidades biologicas }\left(20^{\circ} \% 1 \text {. }\right. \\
8 \mathrm{~mm}) \text {. } \\
\text { B) Poros mamelonares e } \\
\text { policoncavos }(70 \% \text {. } 100 \text { - } \\
1 \mathrm{~mm} \text { ) canais e cavidades } \\
\text { biologicas }(20 \%, 800 \mathrm{~m} \text {. } \\
3 \mathrm{~mm}) \text {. fissuras }(10 \%)\end{array}$ & $\begin{array}{l}\text { A) Fissuras }(100 \mathrm{~m} \text { - } \\
3 \mathrm{~mm}) \text { bern } \\
\text { desenvolvidos, poros } \\
\text { mamelonares }(50 \mathrm{~m}- \\
3 \mathrm{~mm}) \text {. } \\
\text { B) Poros policoncavos e } \\
\text { mamelonares }\left(50^{\circ} \% \mathrm{n}, 50-\right. \\
600 \mathrm{~m}) \text { canais e } \\
\text { cavidades biologicas } \\
(30 \%, 200 \mathrm{~m}-5 \mathrm{~mm}) \\
\text { tissuras }(20 \%, 200 \mathrm{~m} \text {. } \\
10 \mathrm{~mm})\end{array}$ & 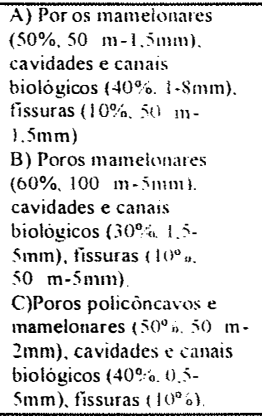 \\
\hline Trama & $\begin{array}{l}\text { A) Porfirica } \\
\text { B) Porfirica }\end{array}$ & Portirica & $\begin{array}{l}\text { A) Portirica } \\
\text { B) Pórfiro-enaulica }\end{array}$ & $\begin{array}{l}\text { A)Porfiro-enaulica } \\
\text { B)Porfirica e porfiro- } \\
\text { enaulica. }\end{array}$ & $\begin{array}{l}\text { A) Porfirica } \\
\text { B) Porfirica abenta } \\
\text { C) Porfirica aberta }\end{array}$ \\
\hline Feicōes & $\begin{array}{l}\text { Presença de ortotubulos } \\
\text { bem desenvolvidos. } \\
\text { Ferriargilās de iluviaçāo } \\
(15 \%) \text { preenchendo os } \\
\text { poros mamelonares e } \\
\text { fissurais. }\end{array}$ & $\begin{array}{l}\text { Presença de ortotubulos } \\
\text { com paredes adensadas e } \\
\text { preenchidos com } \\
\text { microagregados. } \\
\text { Ferriargilãs de iluviação } \\
(30 \%) \text { de cores vermelhas } \\
\text { brilhantes localizadas nos } \\
\text { poros mamelonares. }\end{array}$ & 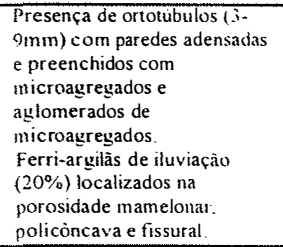 & $\begin{array}{l}\text { Linhas de penetração de } \\
\text { ferro no material } \\
\text { alterado de plagioclàsios } \\
\text { e caulinita. Associação } \\
\text { do ferro com a caulinita } \\
\text { no fundo matricial } \\
\text { formando formas } \\
\text { arredondadas. }\end{array}$ & $\begin{array}{l}\text { Presença de agrotubulos. } \\
\text { Associação do ferro com a } \\
\text { caulinita no fundo matricial } \\
\text { formando formas } \\
\text { arredondadas }\end{array}$ \\
\hline
\end{tabular}

Micromorfologia do Perfil 3. Classificação do solo: Terra Roxa Estruturada, eutrófico, A moderado, textura muito argilosa. 